\title{
Chapter 3 \\ Scientific and Cultural Relations between Heidelberg University and Hungary over Five Centuries
}

\author{
Peter Meusburger and Ferenc Probáld
}

\section{Mobility of Students, Scholars, and Knowledge}

The intellectual acclaim and attractiveness of a university, the scientific and cultural relations between regions, and the spatial diffusion of scientific knowledge and intellectual currents are affected by a host of factors. A main one is the mobility of students and scholars, which has been exceptionally evident since the Middle Ages. Erasmus of Rotterdam (born in Rotterdam between 1464-1469, died in Basle in 1536), Michel de Montaigne (1533-1592), and other humanists held that a person could be truly educated only through travel. They regarded learning through experience to be superior to learning through books and pointed out that travel can hone judgment, broaden a person's educational horizon, and facilitate the acquisition of foreign languages (de Ridder-Symoens, 1996, pp. 416-419; Stagl, 1995, pp. 72, 78-79). For hundreds of years, studying at several foreign universities and going on the peregrinatio animi causa - the Grand Tour, Cavalier's Tour, or study tour-across Europe were vital to the cultivation of the whole person among the elites and figured as the crowning glory of humanistic erudition (see Almási, 2014; Black, 1983, 1992; Chaney, 1998; Heiss, 2005; Horn, 2014; Kühnel, 1964; Miethke, 1995, 2004; Paravicini, 2005). "Between the seventeenth and the early nineteenth centuries the Grand Tour provided the canonical model for aristocratic and bourgeois travel within Europe" (Gregory, 2000, p. 314). In those times, such travel was

\footnotetext{
Some parts of this chapter have already appeared in German (Meusburger, 2010), Hungarian (Meusburger \& Probáld, 2010) and English (Meusburger \& Probáld, 2012). Unless otherwise stated, all translations of originally non-English passages are our own with David Antal.

P. Meusburger

Department of Geography, Heidelberg University, Heidelberg, Germany

F. Probáld $(\bowtie)$

Department of Regional Geography, Eötvös Loránd University, Budapest, Hungary

e-mail: probald.ferenc@gmail.com
} 
instrumental in the spread of knowledge also because books circulated predominantly by means of regionally mobile students (Sienerth, 2007, pp. 286-289).

Geography, history, science studies, and other disciplines have long reflected an interest in connections between travel and the production of knowledge (Almási, 2014; Clifford, 1992; Driver, 2001, 2017; Duncan \& Gregory, 1999; Gregory, 1999, 2000; Horn, 2014; Jöns, Heffernan, \& Meusburger, 2017; Naylor \& Ryan, 2010; Thomas, 2015). Most studies on this subject tend to fall into one of two categories: (a) knowledge acquired on expeditions by researchers and explorers in Africa, South America, and Asia and on travel commissioned by colonial authorities, and (b) knowledge gained through Grand Tours, study tours, and formal learning outside one's home country.

Building on this observation, we discuss some of the salient structural factors that can affect a university's appeal and bear on interregional scientific relations, as exemplified by Heidelberg University and Hungary. Hungary lends itself to this topic because its students were among Europe's most mobile for several centuries. The above-average mobility of Hungarian students resulted in great part from the fact that the universities of Pécs (founded in 1367), Buda (founded in 1395), and Pozsony (Bratislava; founded in 1465) were closed for lack of royal support shortly after they had opened and that other attempts to create universities in Hungary failed as well (see Ábel, 1881; Altmann, 1997; Csizmadia, 1965; Diener, 1963; Domonkos, 1997; Schönebaum, 1926; Szögi, 1995, 2008; Zhang, 2013). ${ }^{1}$ Moreover, the history of studying abroad and knowledge transfer is particularly well documented and researched in Hungary - as shown in the following sections of this chapter.

For lack of universities in their own land, students from Hungary and Transylvania had little choice but to study in another country, making the peregrinatio hungarica the chief vehicle for knowledge transfer between western Europe and the Carpathian Basin for several centuries. From the 1100s through the 1400s, most of the students from Hungary flocked to the universities of Paris, Bologna, Padua, Vienna, Prague, and Cracow. Before the Reformation approximately $66 \%$ of the students from Transylvania studied in Vienna, about 30\% in Cracow, and 3\% to 4\% were distributed across 17 other universities (Offner, 2006, p. 292). In the wake of the Reformation as of the sixteenth century, universities in Germany and Switzerland became the favored destination of students from Hungary and Transylvania. ${ }^{2}$ The educational migration of Hungarian students shifted again in the $1620 \mathrm{~s}$ - this time to the Netherlands-because some German universities had been hard hit during the Thirty Years' War. Some of them had had to interrupt or cease teaching, and a number of famous Protestant professors of German universities had fled to the Netherlands during the Thirty Years' War (Gömöri, 1985; Ladányi, 1997; Murdock, 2000). From the mid-nineteenth century on, students from Hungary once more

\footnotetext{
${ }^{1}$ A Jesuit university was opened in Nagyszombat (today's Trnava in Slovakia) in 1635, but it had only two faculties and was not meant for Protestant students.

${ }^{2}$ Transylvania was ruled by Hungarian princes from the mid-sixteenth century to 1690 , then passed to the Habsburg crown. In 1848 and from 1867 through 1918, the region again formed part of the Kingdom of Hungary. For linguistic reasons, the terms Hungary and Hungarian are sometimes used in this chapter for both parts of the country.
} 
turned to German and Austrian universities, which had regained their leading position.

The ebb and flow of relations between German universities and Hungarian students was not merely a function of the academic reputation of the professors, the changing intellectual standard associated with the universities' locations, or the usually confessional nature of the networks and communicational spaces of German professors. The choice of places at which students from Hungary and Transylvania studied outside their country depended additionally on the political interests of the Hungarian rulers and nobles as well as on military conflicts, confessional disputes, incipient intellectual currents, and worldviews. Among Hungarian students from families of modest means, the choice of where to study hinged also on scholarships conferred by Hungarian nobles and cities; the organizations (coetus) of the Hungarian students themselves at the foreign universities; and a range of free board, grants, and student dormitories or hostels, which varied considerably from one university to the next. ${ }^{3}$ In summary, changes in student migration resulted from the concurrence of spatial rearrangements of intellectual authority and political power, financial and emotional support by communities, and personal relations and networks of scholars.

Of course, students from other countries, too, moved about widely and frequently. The literature on this mobility and the regions from which the universities drew their students (catchment areas) is almost overwhelming (e.g., Birkenmaier, 2012; Courtenay, 2000; de Ridder-Symoens, 1996; Dotzauer, 1977; Fata, 2006, 2014; Fata \& Schindling, 2006; Hebeisen \& Schmid, 2003; Honeck \& Meusburger, 2012; Irrgang, 2003; Maleczek, 1995; Miethke, 1985; Moraw, 1994; Schindling, 2006; Schwinges, 1982, 1984, 1986, 1988, 1994, 1998, 2000, 2001, 2006; Siebe, 2006; Szabó, 1999b, 2006; Szögi, 2001, 2006; Verger, 1970). In relation to population size, however, the intensity and internationality of student mobility from Hungary was more pronounced and enduring than from any other country.

Szögi (2006, p. 388) has stated that approximately 74,000 students from Hungary and Transylvania were enrolled at foreign universities between 1526 and 1919 . Some 39,000 of them were at universities in the Habsburg empire (primarily Vienna, Graz, Prague, and Cracow), around 22,000 in Germany, and about 13,000 in other European countries. The number of those registered is not to be equated with the number of students, however, for most students enrolled at more than one university in the course of their studies. Taking these multiple enrollments into account, Szögi $(2001,2006$, p. 388$)$ has assumed that at least 15,000 students from Hungary studied at German universities in these four centuries.

Heidelberg University (founded in 1386) was selected for this study for several reasons. First, it served for many centuries as a magnet for students from the Carpathian Basin. Second, this university's peak intellectual periods repeatedly fell

\footnotetext{
${ }^{3}$ Compared to students from relatively poor social strata in other countries (see Hebeisen \& Schmidt, 2003; Irrgang, 2003), those from Hungary seemed to have received fairly adequate scholarships and free board, particularly if they were studying theology abroad.
} 
prey to wars, political catastrophes, confessional politics, and existential crises and had to start from scratch several times. Third, the institution's registries contain relatively detailed personal information about the students. Fourth, Heidelberg University played a prominent part in the spread of Protestantism in the Carpathian Basin.

This chapter addresses the questions of which political, social, religious, intellectual, and economic influences helped or hindered the educational migration of Hungarian students to Heidelberg, which regions and social strata the students from Hungary and Transylvania came from, which faculties they enrolled in at Heidelberg University, which leadership functions these students later assumed in their home country, and what sway individual Heidelberg professors had over the cultural, academic, and political development in Hungary and Transylvania. The study covers nearly five centuries but focuses analytically on two historical eras-1595 to 1621 and 1789 to 1919_during which especially close relations existed for various reasons between Heidelberg University and the countries in the Carpathian Basin. We chose these two spans for conceptual reasons but also because of the availability of sources (Heltai, 1982, 1994, 1999, 2006; Szabó, 2005-2007; Szögi, 2001, 2006; Teutsch, 1872; Toepke, 1886; Toepke \& Hintzelmann, 1903, 1904, 1906; Tonk, 1979).

Methodologically, we do not aim to produce a "linearized" or "verticalized" history of the university (Moraw, 1982, p. 2), which is apt to impart a teleological slant to the historical development. Instead, we take a "horizontal approach," as described by the university historian Moraw (1982, p. 2; 1983, p. 525) and recommended by other historians as well (e.g., Schwinges, 2005). Geographers call it context-related research. It directs attention to the complex mutual relations a university has with its social, economic, and political environment (see also the chapter by Meusburger in this volume). The intention is to show the dependence of scientific relations on certain basic conditions; to shed light on the knowledge milieu at university sites; to reveal the intellectual impact that universities, faculties, and individual professors had on cultural, scientific, and political developments in certain regions; and to identify other factors that bear on the academic attraction and growth of a university as well as on the recruitment and mobility of scholars and students.

\section{The First Gilded Age of the Relations between Heidelberg University and Hungary and Reasons for its Decline}

The first mention of a student from Hungary in the registries of Heidelberg University appears in 1502 . For the next six decades, no other student from that country studied at Heidelberg University. ${ }^{4}$ Not until the 1560s did Heidelberg experience a relatively large influx of students from Hungary and Transylvania. This steep rise in

\footnotetext{
${ }^{4}$ Heidelberg University's catchment area in the first half of the sixteenth century was much smaller than that of the universities of Rostock and Greifswald, for example (Schwinges, 1986, pp. 186-187).
} 
Heidelberg University's significance among students from the Carpathian Basin resulted from the confluence of six partly intertwined historical events.

- The reformation ignited by Martin Luther in 1517 and the rapid spread of Protestantism in Hungary.

- The publication of the Heidelberg Catechism in 1563, which quickly reached many areas of Hungary (Kohnle \& Wolgast, 2012).

- The reduction in the importance of the University of Wittenberg because of confessional disputes. Until 1590 Wittenberg had drawn far more students from Hungary and Transylvania than any other German university had, but then it lost many of its students to Heidelberg because of internal conflicts between Lutherans and Calvinists. $^{5}$

- The 150-year Ottoman occupation of central and southern Hungary after the Battle of Mohács in 1526. The partition of Hungary enabled Transylvania to become relatively independent, to resist the Catholic Counter-Reformation, and to become a Calvinist center seeking coalitions with other mainstays of Protestantism in Europe.

- Heidelberg University's close link with the sovereign (Moraw, 1983). ${ }^{6}$ Heidelberg enjoyed status as a Calvinist center of political and intellectual power and as one of the most notable cultural hubs of the late Renaissance. It was a town where famous humanists from all over Europe were active, including many Protestant religious refugees from France and the Netherlands. To Protestants from Hungary and Transylvania in the late sixteenth and early seventeenth centuries, Heidelberg was, in a sense, the "Gateway to Europe" (Heltai, 1982, p. 347).

- The founding of several academically outstanding Protestant academies ${ }^{7}$ in Hungary and Transylvania during the sixteenth and seventeenth centuries (e.g.,

\footnotetext{
${ }^{5}$ Juhász (2010, p. 71), Fata and Millisits (2010, p. 533), and others point out that the terms Calvinist and Calvinism were not used by adherents of the Reformed church to refer to themselves or to their faith until the rebirth of interest in Calvinism in the late nineteenth century. The Reformed population of Transylvania and Hungary declined to be identified solely with Calvin.

${ }^{6}$ Moraw (1983) meant that the Count Palatine of the Rhine (the Heidelberg Prince Elector) closely supervised and controlled Heidelberg University. In particular, the university reform of 1452 was a "clear expression of the sovereign's rule over the university" (p. 526). It was manifested partly in the fact that professors were charged with key responsibilities in service at court and that sons of senior officials at court were appointed as professors (p. 527). Unlike the case in Cracow, for example, where there was a close exchange between the merchant elite and the university (Bernhard, 2015, p. 75), the situation in Heidelberg never allowed for the emergence of a selfconfident mercantile community that had, or even fostered, an interest in the university.

${ }^{7}$ According to Sipos (2010, p. 267), nearly all the professors at the Nagyenyed Academy, a Calvinist school of higher learning, had graduated from foreign universities. The academy also had German professors such as Johann H. Bisterfeld (1605-1665) and Johann H. Alsted (1588-1638), who declined several calls to German universities and other institutions of higher learning (p. 278). Both Bisterfeld and Alsted had studied in Heidelberg.
} 
Pápa, Sárospatak, Debrecen, Kolozsvár, Nagyenyed, Nagyvárad, and Gyulafehérvár. ${ }^{8}$ They prepared their graduates superbly for successful study at foreign universities. "Students sent by the Reformed [i.e., Calvinist] academies to foreign universities constituted the new Protestant educated elite, who brought Calvinist doctrine and its educational ideals to Hungary and Transylvania" (Fata \& Schindling, 2010, p. x)

In the following sections we first explain some of these influences and contexts at a structural level and then illustrate them further through the biographies of selected scholars, intellectuals, and politicians. The examples are also intended to show how sensitive a university system is to the world around it, how the centers of scientific knowledge production repeatedly move from one city to another, ${ }^{9}$ and how much impact the social networks of professors and students can have on the knowledge transfer between elites of different countries, on the cultural development of regions, and on the diplomatic relations between countries.

\section{Heidelberg as a Political and Intellectual Center of Calvinism}

Like the creation of many other universities in the late fourteenth and early fifteenth century, the founding of Heidelberg University in 1386 did not serve the local population but rather the interests of its founder-the most powerful of the Holy Roman Empire's seven Prince Electors ${ }^{10}$ - aggrandizing his power by increasing his prestige and the resources of his dominion. In 1559, under the rule of the first Calvinist Prince Elector, Frederick III (ruled from 1559 to 1576), Heidelberg became a ranking European spiritual and political center of Calvinism and a fulcrum of antiHabsburg diplomacy, having large sway over imperial policy. ${ }^{11}$ As a thriving hub of the late Renaissance and Humanism in the sixteenth century, Heidelberg University's intellectual beacon radiated throughout Europe. Humanism did much to spread the Reformation in Hungary, with many Hungarian humanists embracing the new religious movement (Bernhard, 2015, p. 227).

As Kohnle (2001), Seidel (2004), Wolgast (1998), Zepf (2001), and others have written in their detailed accounts, Heidelberg University's professors have never been

\footnotetext{
${ }^{8}$ The German place name of Gyulafehérvár was Weißenburg. Today it belongs to Romania and is called Alba Julia. For the sake of consistency and readability in this chapter, we generally use the Hungarian names to refer to Hungarian places.

${ }^{9}$ On the shift of the European research centers in the natural sciences between 1500 and 1900, see, for instance, Hoyler and Taylor (2012) and Taylor, Hoyler, and Evans (2010).

${ }^{10}$ The seven Prince Electors held the privilege of electing the King of the Germans and future Holy Roman emperor. Such elections took place when a dynasty changed, but they were also needed by the son of the reigning king in order to be approved by the Prince Electors as his father's rightful successor. The most important of the seven Prince Electors resided in Heidelberg.

${ }^{11}$ Heidelberg at that time was called "the center of Calvinist-Reformed academia" (Wolgast, 1986, p. 40) and the "international Mecca of the anti-Spanish, anti-Roman intelligentsia" (Wolgast, 1996, p. 293).
} 
as scientifically, culturally, and politically influential and as internationally well networked as in the years from 1560 to 1622 . The electoral court in Heidelberg and the university attracted officials, scholars, and students from many parts of Europe, particularly from territories with populations having a high percentage of Calvinists or in which Calvinists were politically persecuted. Many humanists were also scholars, poets, ambassadors, and policy advisors at court. Heidelberg University's faculties all boasted internationally renowned and prolific scholars whose thoughts and works disseminated in all of Europe by means of literary Latin. The Heidelberg humanists corresponded with scholars, diplomats, and princes in many areas of Europe, were embedded in international networks, and were academically highly mobile (see BaarCantoni \& Wolgast, 2012; Kühlmann, Hartmann, \& El Kholi, 2012; Neumaier, 2012b; Strohm \& Becker, 2012; Strohm \& Hofmann, 2012; Wolgast, 1998). The internationality of Heidelberg University, which was astonishing for that period, was apparent partly in the fact that 11 of the 16 professors teaching in the Faculty of Theology between 1559 and 1622 were foreigners. Four more hailed from other territories of Germany, and only one had been born in the Electoral Palatinate (Wolgast, 2015, p. 92). Of these 16 professors, 11 had been persecuted for their Protestant faith at the places where they used to work (in the Spanish Low Countries, France, Italy, and eastern central Europe) (p. 92). The 17 rectors $^{12}$ elected between December 1559 and December 1575 included 3 from Italy, 1 from France, 3 from the Low Countries, 1 from Switzerland, and 3 from the Holy Roman Empire outside the Palatinate (Kohnle, 2001, p. 145). The students were of similarly international provenance. In 1563, 40.3\% of them were foreigners; between 1564 and 1609, the share of foreigners in the student body usually exceeded 50\% (Kohnle, 2001, p. 153).

\section{Conditions and Factors that Promoted the Spread of Protestantism in Hungary}

After the capitulation of Buda in 1541, southern and central Hungary belonged to the Ottoman empire. The west and north of Hungary constituted the Kingdom of Hungary and stood under Habsburg rule, and the principality of Transylvania in the east enjoyed relatively great political independence under Ottoman suzerainty. ${ }^{13}$ To protect this independence from the House of Habsburg, which was Catholic, the

\footnotetext{
${ }^{12}$ In much of continental Europe, the rector is traditionally a university's highest academic official.

${ }^{13}$ Transylvania was obliged to consult the Ottomans only on important matters of foreign policy and paid annual tribute to the sultan.
} 


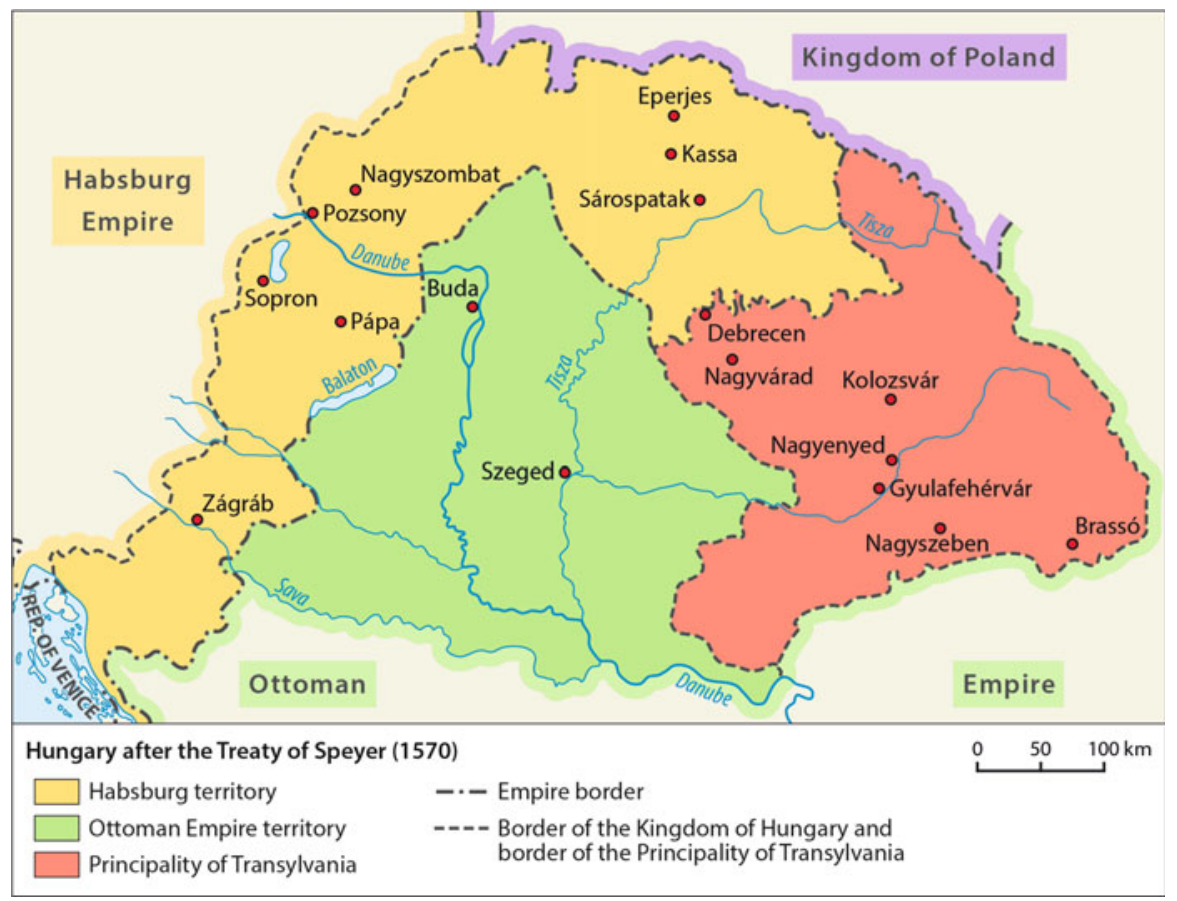

Fig. 3.1 The partition of the Kingdom of Hungary after the Treaty of Speyer, 1570 .

Sources: Fata (2000, p. 17), Glatz (1995, p. 61). Design by the authors. Cartography: U. Selgert, V. Schniepp.

princes of Transylvania were interested in cultivating close cultural, scientific, and political relations with Europe's Protestant centers of power. ${ }^{14}$

The tripartite political division of Hungary (Fig. 3.1) had an abiding effect on the conditions framing ecclesiastical policy in the Reformation and Counter-Reformation (or re-Catholization) and led to dissimilar confessional structures and student mobility in the three regions. According to Benda (1976), between $80 \%$ and $85 \%$ of the population in Hungary was Catholic in 1525. The rest consisted of Orthodox Christians, Jews, heretics, and other groups. Between 1570 and 1620 some $75 \%$ to $80 \%$ of Hungary's population turned to embrace Protestantism, with only about $10 \%$ remaining Catholic (Benda, 1976; Murdock, 2000; Szabó, 2010; Zach, 2004, pp. 159-160). Backed by the aristocracy as of the 1540s, the Reformation surged through the Habsburg part of Hungary (western and northern Hungary), with most of the Germans and Slovaks being Lutheran and most of the ethnic Hungarians being Calvinist (Asche, 2004). At that time the Protestants dominated the educational system and letterpress printing. Of the 168 grammar schools that existed in Hungary

\footnotetext{
${ }^{14}$ Calvinism in Transylvania and eastern Hungary also greatly contributed to the rise of a political identity among ethnic Hungarians.
} 
in the sixteenth century, 134 were Protestant (Bucsay, 1977, p. 161), and Protestants wrote an estimated $90 \%$ of the more than 500 books printed in Hungarian in the sixteenth century (p. 159).

In the Ottoman part of Hungary, Lutheranism and the Reformed church spread unhindered, whereas the organized Catholic church steadily weakened. Islamization of the native population did not occur in central Hungary (Asche, 2004, pp. 38-39; Bernhard, 2015, p. 447; Zach, 2004, p. 160). Transylvania became the center of ascendant Calvinism in the Carpathian region of the sixteenth century, and in the seventeenth century it long resisted the Counter-Reformation led from the west by Peter Pázmány (1570-1637), who became archbishop of Esztergom in 1616 (Höchsmann, 1894-1895, 1896-1897) and cardinal in 1629 (on Pázmány’s role see Bucsay, 1977, pp. 164-167).

The University of Wittenberg and Heidelberg University became focal points for students from Hungary and Transylvania after the Reformation (Szabó, 1992, 1999b, 2006) because these two institutions were linked with four of the most eminent authorities of Protestantism: Martin Luther (1483-1546), Philipp Melanchthon (1497-1560), Zacharias Ursinus (1534-1584), and David Pareus (1548-1622). Not only were the first two men towering figures in Wittenberg, their names became closely associated with Heidelberg as well. With Luther, the latter connection took root just months after his 95 theses appeared in Wittenberg, for he received the opportunity to air and defend his ideas on reform publicly in a disputation, or scholarly debate at Heidelberg University (Baar-Cantoni, 2012; Mühlen, 1985; Scheible, 1983; Seebaß, 1983). This encounter, during which he presented his doctrine of justification in a series of assertions, or premises, took place on April 26, 1518, in the lecture hall of the Faculty of Philosophy (corresponding to the Arts and Humanities in a modern U.S. context). A good dozen of the students attending the event went on to become notable reformers in southern Germany (Baar-Cantoni, 2012, p. 57).

\section{Philipp Melanchthon}

Heidelberg's second connection to Protestantism came through Philipp Melanchthon (Fig. 3.2), an intimate friend of Martin Luther. Melanchthon was a remarkable, immensely authoritative reformer, humanist, church policy-maker, university reformer, and educator. Without his organizational skill as a Protestant negotiator in imperial diets and religious discussions, the Reformation might well have taken a less successful course than it did. ${ }^{15}$ Melanchthon "began his path to Calvinist theology . . . in Heidelberg, continued it in Tübingen, and completed it in Wittenberg" (Rieger, 2010, p. 153). He was born in Bretten, about 30 miles south of Heidelberg. Extraordinarily gifted, he was permitted to enroll at Heidelberg University on October 14,1509 , when he was just $12 \frac{1}{2}$ years old. He earned a baccalaureate

\footnotetext{
${ }^{15}$ This summary of Melanchthon's biography and magnitude is based on Greschat (2010), Jesse (2005), Lorenz (2010), Köpf (2010a, 2010b, 2010c), Rieger (2010), Schweitzer, Lorenz, \& Seidl (2010), Stempel (1993), and Stupperich (1990, 1996).
} 
Fig. 3.2 Philipp Melanchthon. Source: Heidelberg University Archives. Reprinted with permission.

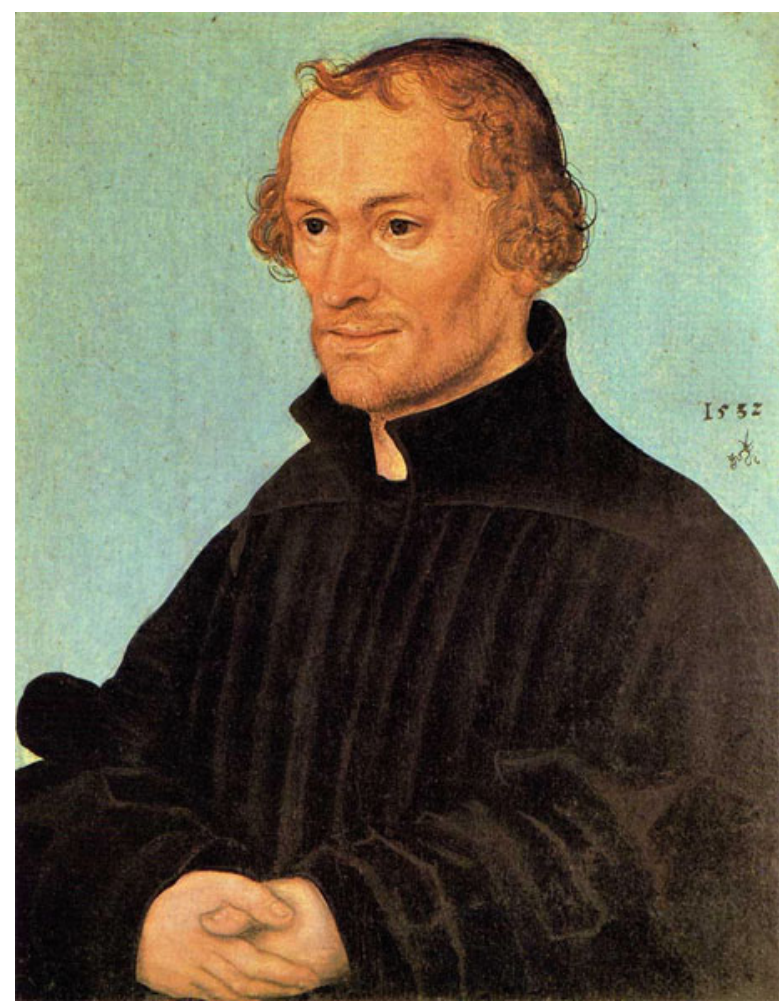

by the age of 14. In September 1512, Melanchthon transferred to the University of Tübingen, where in January 1514, not yet 17 years old, he completed his Magister artium (the academic degree common at that time for philosophical, linguistic, cultural, or historical subjects in the arts and humanities). ${ }^{16}$

At the age of 21, Melanchthon was appointed to the newly created chair of Greek at the University of Wittenberg, where he deeply impressed Martin Luther and other scholars with his brilliant inaugural lecture on the need for extensive academic reform. In the winter semester of the academic year beginning in 1523, he became the rector of the University of Wittenberg for the first time. He formulated new university statutes, reformed the curriculum, proved to be an excellent organizer, wrote commentaries on ancient Greek authors, and composed noteworthy textbooks

\footnotetext{
${ }^{16}$ On Melanchthon's activity at the University of Tübingen, see Köpf (2010a, 2010b, 2010c) and Lorenz (2010).
} 
on Greek,${ }^{17}$ rhetoric, ethics, physics, ${ }^{18}$ history, and geography. His analytical reports and recommendations helped shape the university reforms in Frankfurt on the Oder, Marburg, Tübingen, Greifswald, Rostock, Leipzig, Jena, and Heidelberg (Asche, 2010, p. 82; Köpf, 2010b, p. 25). Melanchthon was also probably one of the first people to recognize the unmistakable import that the school system has for a country's economic development (for details see Meusburger, 2013, p. 22). A paramount figure of German intellectual life, he was acclaimed by his contemporaries as Praeceptor Germaniae - the teacher of Germany (for details see Frank \& Treu, 2001; Gebhardt, 2008; Rieger, 2010). Perhaps no other scholar of his day was as communicative and persuasive as he, or as well connected with so many leading educational institutions, learned societies, humanist circles, cities, church administrators, and princely and royal courts.

Melanchthon is also an example of how much networks, webs of relationships, and knowledge milieus can mean for the academic socialization and later careers of students. He illustrates how much the intellectual appeal of universities is marked by the people working there and by their range of contacts. Melanchthon's strongest ally was his great uncle, Johannes Reuchlin (1455-1522), the humanist, diplomat, distinguished Hebraic language scholar, and pivotal man in a key European network. When Prince Elector of Saxony Frederick the Wise (1463-1525) — who had founded the University of Wittenberg in 1502 (see Stievermann, 1999)—asked Reuchlin to recommend a suitable candidate for the recently created chair of Greek in Wittenberg, Reuchlin named his student and grandnephew, Melanchthon. Reuchlin had already paved the way for him in Heidelberg and Tübingen (for details see Köpf, 2010b, pp. 29, 37). Like his great uncle, Melanchthon himself later became the heart of a European-wide personal network from which students from Hungary and Transylvania especially benefited.

Owing to his personal contacts and extensive correspondence, Melanchthon was exceptionally well informed about Hungary and Transylvania (see Scheible, 1985). By 1521 his friend and former fellow pupil from grammar school days in Pforzheim, Simon Grynaeus (1493-1541), had become the school director of St. George's Chapel at the royal castle in Buda and librarian of the Corvinus library, one of Europe's best at that time. ${ }^{19}$ Grynaeus became a professor at Heidelberg University in 1524 and at the University of Basle in 1529 (Scheible, 1985, pp. 37-38).

\footnotetext{
${ }^{17}$ Melanchthon's book on Greek grammar appeared in 1518 and underwent its 17 th printing in 1544. It became the most widely used schoolbook in Europe's Reformed regions (Rieger, 2010, p. 153).

${ }^{18}$ Melanchthon rejected the heliocentric concept of the world, however (Reich, 2010, p. 140).

${ }^{19}$ The library's destruction after the Ottoman conquest of Buda (1541) was an incalculable loss of culture and knowledge and ultimately hindered the exchange of knowledge between Buda and other European countries.
} 
Melanchthon was in touch with the most prominent exponents of the early Protestant movement in Buda. ${ }^{20}$ One of the first people to spread Melanchthon's ideas in the Carpathian Basin was Mátyás Dévai Biró (?-1547), Hungary's celebrated reformer, who was the second Hungarian to enroll at the University of Wittenberg (1529). He was a reformer in various locations of western and northern Hungary after 1538, later in Transylvania as well (Bernhard, 2010, pp. 37, 47). Other major theologians of the Hungarian and Transylvanian Reformed church, such as István Szegedi Kis (1505-1572) and Péter Méliusz Juhász (1532-1572), had likewise studied under Melanchthon (Juhász, 2010, p. 65).

While in Wittenberg, Melanchthon attracted students from Hungary and Transylvania and was probably one of the main reasons why Hungarian students found Wittenberg to be the most desirable university in Germany for several decades. Wittenberg in the sixteenth century accounted for $68.4 \%$ of all academics among the Transylvanian "Saxons", ${ }^{21}$ in the seventeenth century, 41.3\% (Offner, 2006, p. 292). A few of the Hungarian students-such as György Albani Csirke, who later became the Holy Roman Emperor's ambassador to the Ottoman court-lived in Melanchthon's house, and he held lectures and devotions in Latin for Hungarians who had not yet mastered German (Bernhard, 2010, p. 49; Szabó, 2010, p. 86).

Melanchthon's publications circulated widely in Hungary and Transylvania. As an undisputed authority on theology and education, Melanchthon wrote numerous expert reports-recommendations for Hungarian and Transylvanian clergy, teachers, city councilors, and officials. Melanchthon's Confessio Augustana variata (Altered Augsburg Confession) of 1540 also served as the model for the rules governing church life, belief, and worship in the royal free cities and the mining towns of upper Hungary, the German municipalities in the Zips region (today a region in northeastern Slovakia; Slovakian Spiš, Hungarian Szepes), and the Transylvanian towns (see Asche, 2004, pp. 36-37). Because Melanchthon exerted considerable influence on Hungary's cultural elite, he was (and is) occasionally also known as Praeceptor Hungariae - the teacher of Hungary (Beck, 2016).

For students from Hungary and Transylvania, Wittenberg was undeniably the premier German university in the sixteenth century (Fig. 3.3). More than half of the approximately 4,300 Hungarian students who attended German universities in the sixteenth and seventeenth centuries were enrolled at Wittenberg, followed by Frankfurt on the Oder, Leipzig, Jena, Heidelberg, and Tübingen (Tar, 2007, p. 19).

Wittenberg did not lose this position until the reign of Saxon Prince Elector August (1553-1586), when orthodox Lutherans and Melanchthon's supporters clashed over the theological question about the nature of the Lord's Supper. Melanchthon's students were belittled as Crypto-Calvinists or Philippists,

\footnotetext{
${ }^{20}$ Many of the Protestant humanists fled Buda for Germany after the city's capitulation to the Ottomans. Hungary's manifold close economic relations with the rest of Europe were thenceforth heavily restricted.

${ }^{21}$ In Transylvania all German-speakers were called Saxons. The term has nothing to do with the territory of Saxony.
} 


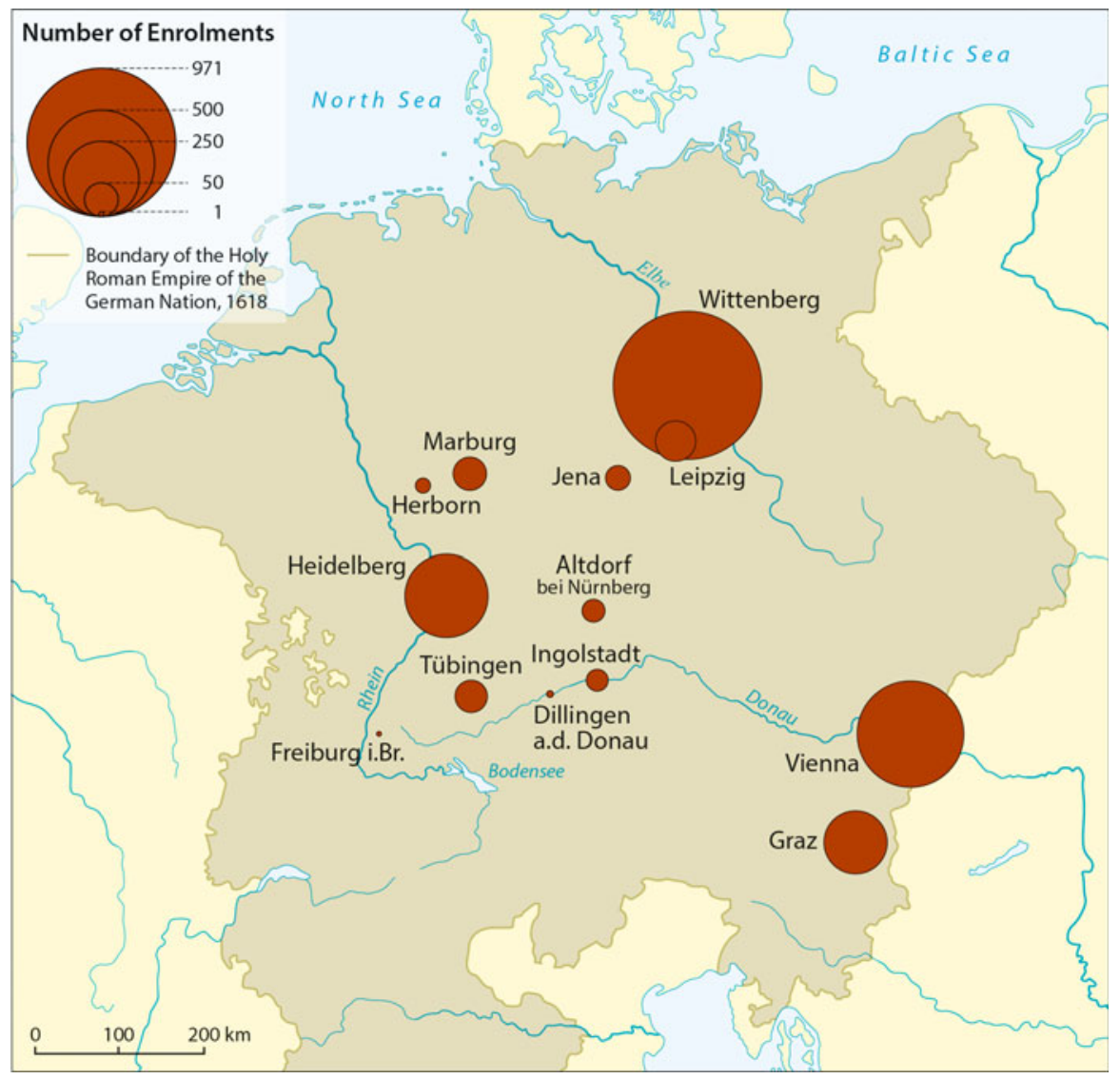

Fig. 3.3 Hungarian students at German universities, 1560-1620.

Data sources: Heltai (1982, 1999); Teutsch (1872). Basic map: Leibniz-Institut für Länderkunde, Leipzig (IfL). Cartography: V. Schniepp.

systematically persecuted, and finally driven from the university once and for all in 1592. The waves of purges and subsequent unrest eventually eroded the intellectual level and reputation of the University of Wittenberg (Ludwig, 2009; Szabó, 1993). The Calvinist students from Hungary and Transylvania thereafter looked to Heidelberg, with Wittenberg remaining acceptable only to Lutheran students of theology.

\section{Zacharias Ursinus and the Significance of the Heidelberg Catechism}

The Heidelberg Catechism (Fig. 3.4), published by Zacharias Ursinus (Fig. 3.5) by commission of Prince Elector Friedrich III in 1563, Count Palatine of the Rhine, 


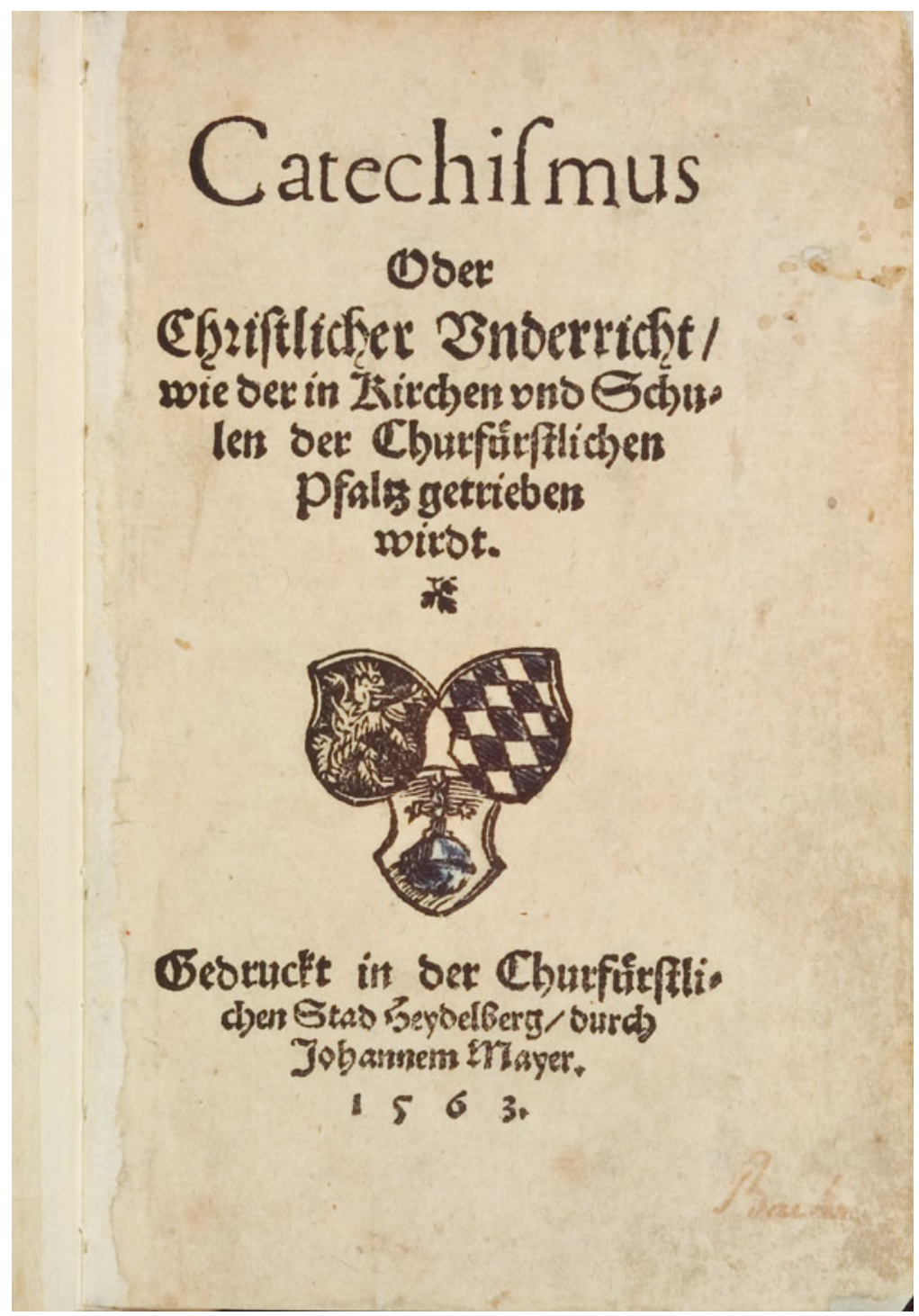

Fig. 3.4 Title page of the first edition of the Heidelberg Catechism in 1563. Source: Heidelberg University Archives. Reprinted with permission.

galvanized the cultural relations between Heidelberg and Hungary. ${ }^{22}$ The document not only incorporated Calvin's teachings but also articulated its own theological position, which assimilated seminal theological ideas of Calvin, Melanchthon, and Protestants of northern Switzerland. The aim was to harmonize and intelligibly

\footnotetext{
${ }^{22}$ Presumably, other Heidelberg University theologians also worked on the Catechism (see Wolgast, 2015, p. 89).
} 
Fig. 3.5 Zacharias Ursinus, key author of the Heidelberg Catechism.

Source: Heidelberg University Archives. Reprinted with permission.

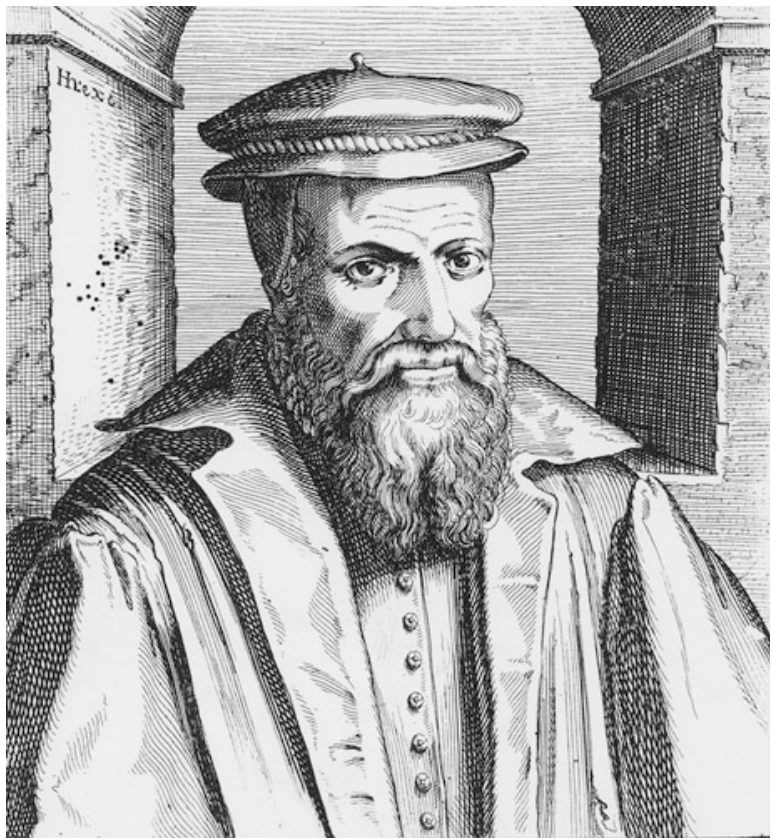

reconcile the increasingly doctrinaire and divergent views held by orthodox Lutherans and Calvinists (for details see Bierma, 2015; Henss, 1983; Millisits, 2012; Módis, 1967; Nagy, 1967; Schilling, 2010; Zach, 2004).

In 1564 a disagreement over the Lord's Supper arose in Transylvania between the preachers of the primarily German-speaking Lutherans and the ethnic Hungarians, who espoused Calvin's teachings. The clerics eventually asked the famous Heidelberg theologians for their opinion on the thorny theological concern. The Heidelberg professors responded with a letter in which they set forth their standpoint and referred the Hungarian fellow Christians to the new Heidelberg Catechism. ${ }^{23}$ The letter was printed in Kolozsvár (today's Cluj-Napoca) in 1565 and published under the title Epistola Professorum Theologiae Academiae Heydelbergensis (Epistle by the Professors of Theology at Heidelberg University). The Heidelberg Catechism itself was initially printed in Kolozsvár the next year-an edition that did not yet contain certain critical passages. The complete Hungarian translation appeared in 1577 (Bartha, 1967; Millisits, 2012; Nagy, 1967, p. 41). The Heidelberg Catechism was so successful that it soon supplanted the other Protestant catechisms existing in Hungary at the time.

Another explanation for this swift acceptance is surely that the Heidelberg Catechism offered the analytical culmination (Zach, 2004, p. 162) of what some Hungarians had tentatively already begun trying to formulate - a comprehensible compromise between the disparate Protestant doctrines. Nagy (1967, p. 32) pointed

\footnotetext{
${ }^{23}$ Bernhard (2015, p. 438) assumes that the original text of the Heidelberg Catechism was known in the eastern parts of Hungary by late 1564 .
} 
out that the German translation of the briefer confession written by the French reformer Theodore Beza (also called Théodore Bèze, 1519-1605) appeared in Heidelberg in 1562 and verifiably informed many passages of the Heidelberg Catechism. Hence, the Heidelberg Catechism was inspired by the same Beza whose longer statement of confession had been adopted by the Hungarians as their own at the Synods of Tarcal (1562) and Torda (1563). This circumstance certainly helps account for the ready reception of the Heidelberg Catechism in Hungary. The national synod of Szatmárnémeti in 1646 recognized the Heidelberg Catechism along with the fundamental Second Helvetic Confession as the second authentic doctrinal tract of the Reformed church of Hungary and Transylvania. These synods mandated that theology students swear an oath before and after studying outside Hungary that they would always conform to the doctrine laid out in the Heidelberg Catechism.

The Heidelberg Catechism was translated into English, French, Hungarian, Czech, and Romanian as early as the seventeenth century (Ehrenpreis, 2015, p. 312). Before long it was obtainable in 40 languages and was eventually reissued 150 times in Hungary alone (Baar-Cantoni \& Wolgast, 2012, pp. 67-69; Henss, 1983; Zach, 2004, p. 163). ${ }^{24}$ Such wide dissemination owed not least to the tract's availability in the native languages of several Protestant countries, where they were used to teach reading in schools in the sixteenth and seventeenth centuries (Ehrenpreis, 2015, p. 315). In that instructional capacity the Heidelberg Catechism decisively shaped the educational systems of Hungary, and other Protestant areas for centuries (Nagy, 1967, p. 48). Under Habsburg absolutism, however, some of its paragraphs were censored, so several Hungarian publications of it could appear only as abridged editions.

\section{David Pareus as a Main Authority on Calvinism and an Instrumental Councilor to the Ruler of Transylvania}

For more than two decades the greatest intellectual magnet drawing Calvinist students from Hungary and Transylvania was the Heidelberg professor David Pareus (Fig. 3.6), a student of Zacharias Ursinus. Pareus held a chair at Heidelberg University from 1598 to 1621 and was regarded in Hungary and Transylvania as the supreme authority on Calvinist orthodoxy. The magnitude of Pareus's impact on the spiritual, cultural, and political development in Hungary and Transylvania is partly evident from the fact that Pareus chaired 293 disputations ${ }^{25}$ by Hungarian

\footnotetext{
${ }^{24}$ The most recent Hungarian translation of the Catechism was published in 2013 in commemoration of the Confession's 450th anniversary.

${ }^{25}$ From the Middle Ages until after the dawn of modern times, the disputatio was one approach to scientific exchange and the foremost method of resolving scientific disputes. In this regard it differs from the defense of a dissertation today - the oral examination in partial fulfillment of the requirements for a doctorate. Hence, some of the 173 students from Hungary mentioned by Heltai (1982, 1999) faced more than one disputatio.
} 
Fig. 3.6 Portrait of David Pareus.

Source: Heidelberg University Archives. Reprinted with permission.

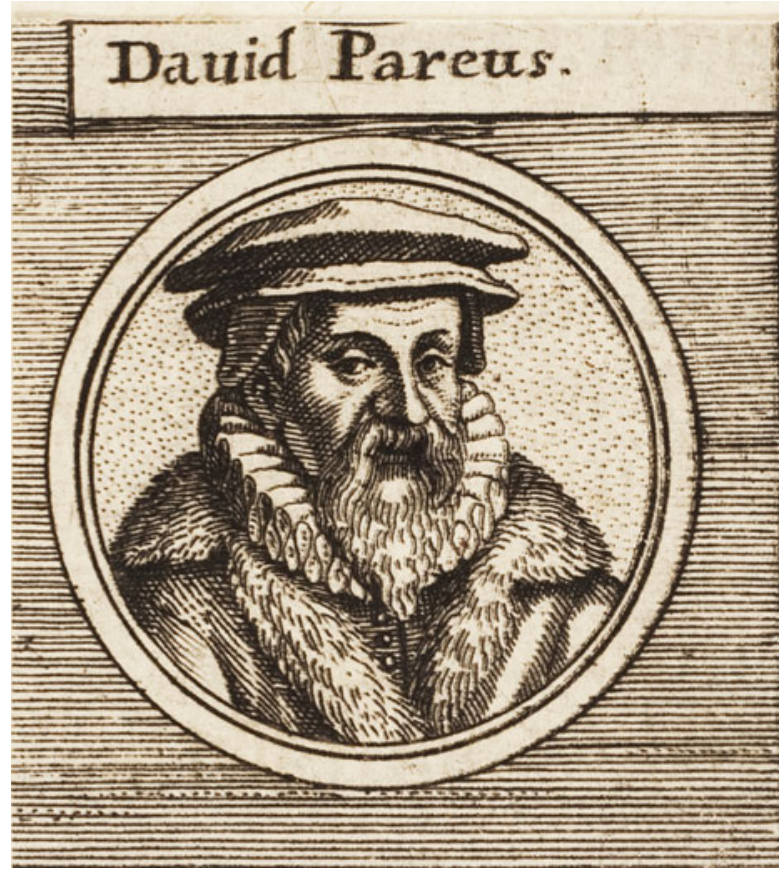

students $-92 \%$ of all the disputations by Hungarian students in Heidelberg at that time (Heltai, 2006, p. 68; Ulrichs, 1993), and many of his former students took over important functions in Hungary and Transylvania. In Pareus's summer house, the Pareanum at the foot of the Schlossberg, the Hungarian students would meet with their professors and fellow students for convivial conversation (Röhrs, 1971, p. 7), not only discussing theological topics but also making personal friends and building academic networks that were later cultivated in lively exchanges of letters (Seidel, 2004, p. 246). Pareus's students from Hungary and Transylvania obviously had fond memories of this time. Writing to Pareus in 1609, the nobleman Újfalvi Katona (1572-1610) described the four months he had spent in Heidelberg as a scientifically stimulating, all-too brief interlude compared to his more than two years in Wittenberg, which he characterized as having been nothing but a waste of time and money (Seidel, 2004, p. 232).

After returning to Hungary or Transylvania and advancing to high positions and offices, they continued to regard Pareus as the highest authority and to seek his counsel on daily matters of church practice. Pareus kept himself thoroughly informed about events in Hungary and Transylvania and maintained a lively correspondence with the reigning prince in Transylvania, Gábor (Gabriel) Bethlen (1580-1629), who ruled 
from 1613 to $1629^{26}$ and held Pareus to be the preeminent interlocutor in the Reformed world. Pareus enthusiastically welcomed and endorsed the prince's project of founding a Calvinist academy in Gyulafehérvár/Weissenburg. It is partly due to Pareus's advice that this school's regulations were modeled on educational institutions in the Electoral Palatinate and Hesse. One of the people Bethlen brought to Transylvania to help develop the academy in Gyulafehérvár/Weissenburg was the German scholar Johann Heinrich Bisterfeld (1605-1655), a student of Pareus. Bisterfeld remained there for 25 years as the leading professor, built a dense European network of personal contacts with scholars and princes with whom he corresponded frequently, and took part in crucial diplomatic negotiations on several occasions (Viskolcz, 2010).

Gábor Bethlen assured Pareus in a letter that he was very impressed by Irenicum (1614, Pareus's chief work) and "holds it in his hands day and night" (Seidel, 2004, p. 247). The irenic theology that Pareus authentically practiced, which may be seen as a forerunner of today's ecumenical undertakings, emphasized the shared foundation of the Christian faith and rejected both religiously rooted violence and harsh theological polemics (Hotson, 1995, 2004). This notion was embraced by most of Pareus's students, too, and was fully consistent with the interests of the prince, whose reign was beset by foreign and domestic tensions. Although Gábor Bethlen favored the Calvinist (Reformed) church above all, he did set store in avoiding an escalation of religious conflict. He had to keep in mind Transylvania's exceedingly complicated confessional circumstances, which had moved the provincial diet to adopt a law of unprecedented tolerance guaranteeing religious freedom as early as $1568 .^{27}$

It would be wrong, however, to reduce Pareus's significance solely to Hungary and Transylvania. Between 1599 and 1619 he conducted over 400 disputations and profoundly influenced students from many European countries, such as the Prague scholar Comenius ${ }^{28}$ who studied for a year at Heidelberg University in 1613-1614 and engaged in a formal scholarly debate (disputatio) with Pareus in the Faculty of Theology on March 19, 1614 (Hotson, 1995, pp. 438, 450-453; Röhrs, 1971, p. 5). Despite the brevity of his study in Heidelberg, the impression on him was lasting (on the nature of the teaching that Comenius received in Heidelberg and on the content of his theses, see Hotson, 1995). Pareus and his Irenicum underpinned the thoughts behind Comenius's efforts to end to the naval war between England and Holland and behind his general exhortations in Panorthosia (Universal Reform) for

\footnotetext{
${ }^{26}$ Bethlen had acquired his title of prince in 1613 with the active support of the Sublime Porte (the Ottoman feudal government, with the sultan and his court at its center) but against the resistance of the court in Vienna. He was thereafter able to consolidate Transylvania's independence. In 1620 he was elected as king of Hungary but refused to be crowned. In 1621 he had to renounce the Hungarian crown forever in the Peace of Nikolsburg.

${ }^{27}$ There were three recognized Protestant confessions in Transylvania in the early seventeenth century. Some of the nobility and the Szekler were Catholic, and the Romanians have always remained Greek Orthodox despite repeated Protestant attempts to convert them (Leppin \& Wien, 2005).

${ }^{28}$ Comenius registered under the name Johannes Amos Niuanos Moravus, perhaps one reason why he has received relatively little attention in the history of Heidelberg University thus far (Röhrs, 1971, pp. 2-5).
} 
princes to strive for peace and security (p. 8). Comenius dedicated the foreword of his Unum Necessarium (The One Thing Necessary, 1668) to Friedrich V's son, Ruprecht, who was living in exile in London (p. 11). Comenius traveled to Hungary in 1650 and taught there for four years at the Calvinist academy in Sárospatak, where he wrote his famous works Orbis sensualium pictus (The Visible World in Pictures; see Comenius, 1705) and Schola ludus (School by Play).

\section{Fluctuation in the Number of Students}

Journeying constantly from one place of learning to another (peregrinatio academica), the students from Hungary and Transylvania were well networked with each other. They therefore usually responded quickly to scientific disputes, religious conflicts, crises at universities, and turns in the political and social conditions in Germany and Hungary. When Heidelberg University reverted to Lutheranism under Prince Elector Ludwig VI (ruled 1576-1583), many professors had to leave Heidelberg because the ruler's religion dictated that of the subjects (the principle of cuius regio, ejus religio). Not only did this exodus lower the university's intellectual caliber, the confessional shift also meant that no students from Hungary or Transylvania enrolled there between 1578 and 1582. Not until 1583, under Calvinist Prince Elector Friedrich IV (ruled 1583-1610), did the numbers of students from Hungary, Transylvania, and other parts of Europe soar again (Kohnle, 2001, p. 147). For about 30 years after the expulsion of the Crypto-Calvinists from the University of Wittenberg in 1592 (see section on Philipp Melanchthon, above), Heidelberg University became the key German university for students from Hungary and Transylvania (Fig. 3.7). A consequence of the Bocskay uprising ${ }^{29}$ against the Habsburgs (1605-1606) and the clashes with the Ottomans was that the number of Hungarian students temporarily plummeted again in the early seventeenth century (Fig. 3.7). It then recovered, peaking between 1608 and 1621. As Heltai (2006, pp. 68,72) has reported, the flood of Hungarian and Transylvanian students to Heidelberg University after 1614 also stemmed from the fact that contours of a European alliance of Protestant princes began to emerge after the marriage of Prince Elector Friedrich V, who resided in Heidelberg, to Elizabeth Stuart, the daughter of James I, King of England (James VI, King of Scotland) in 1612-1613 (see Marshall, 2003). Gábor Bethlen wanted to join this coalition of Protestant rulers, so he promoted the tide of Transylvanian students to Heidelberg for political reasons. Assisted by his students, Bethlen succeeded in intensifying his contacts to the court of the Heidelberg Prince Elector to "break out of political isolation" (Heltai, 2006,

\footnotetext{
${ }^{29}$ István Bocskay was elected prince of Transylvania (1605) and led an uprising against the Habsburg emperor Rudolf II., king of Hungary. In the Treaty of Vienna (1606) various constitutional and religious rights and privileges were granted to the Hungarians in both Transylvania and Royal Hungary. The accord also recognized Bocskay as the Prince of Transylvania and guaranteed the right of Transylvanians to elect their own independent princes in the future.
} 


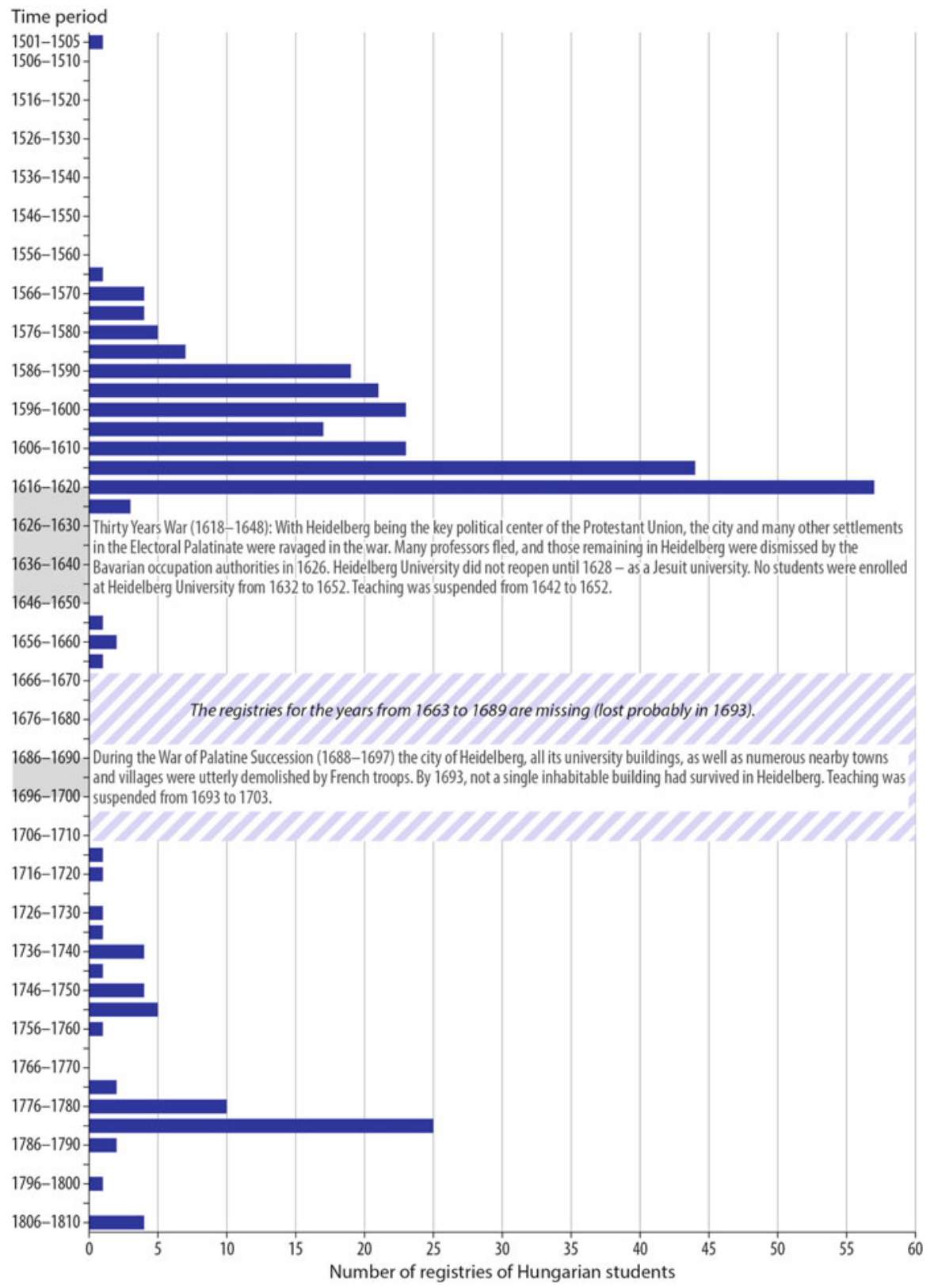

Fig. 3.7 Students from Hungary and Transylvania studying at Heidelberg University, 1500-1810. Data sources: Heltai $(1982,1999)$; Teutsch (1872). Design by authors. 
p. 73). The Heidelberg peregrination vitally contributed to bringing Transylvanians into the Thirty Years' War on the side of the Protestant princes (p. 73).

\section{Social Origins, Choice of a Place to Study, and Choice of Occupation of the Students from Hungary and Transylvania, 1595-1621}

Hungary's tripartite division affected not only the confessional profile of the Hungarian and Transylvanian students abroad but also their political interests, diplomatic relations, and choice of where to study. The Catholics preferred the Catholic universities of Graz, Vienna, and Cracow. The Lutherans, who accounted for most of the German-speaking population in Hungary and Transylvania, usually chose to study at German universities at which Lutheran professors predominated. The Calvinists gravitated mostly to Heidelberg, Geneva, and, after the outbreak of the Thirty Years' War, to universities in the Low Countries (see Hotson, 2008; Murdock, 2000; and the chapter by Hotson in this volume).

Heltai $(1982,1999)$ has reported that 175 students from Transylvania and Hungary enrolled at Heidelberg University between 1595 and 1621, almost all of them Calvinist Hungarians. The vast majority of the students came from the urban middle class, which was still relatively small then. In the sixteenth and seventeenth centuries, an era in which both society and politics revolved around issues of religion, clerics, especially the famous preachers, could achieve high standing. A church career at that time offered very attractive paths of upward social mobility for the sons of artisans, merchants, free peasants, and even a few serfs. ${ }^{30}$ Students whose families could not afford to have them study outside Hungary could apply for a scholarship from the magistrate of the area in which they lived, from aristocratic patrons, or from the prince himself. Preachers' sons who intended to follow their fathers into the ministry were particularly well represented among Heidelberg students. Only about $8 \%$ of the students from Hungary and Transylvania were nobles.

Reconstructing the careers of 109 of the 175 Hungarian students who studied in Heidelberg between 1595 and 1621, Heltai $(1982,1999)$ found that 10 graduates had later pursued a secular occupation, 11 had gone on to employment as teachers in the church schools, and 88 had become preachers (pastors) in the Reformed church in Hungary or Transylvania. Of these clerics, 29 rose to the rank of deacons, and 10 became superintendents (comparable to a Catholic bishop) - key positions in the Calvinist church hierarchy, which was rapidly expanding in that era (for details see Heltai, 2006). ${ }^{31}$

\footnotetext{
${ }^{30}$ In Transylvania the freedom of learning was legally guaranteed for serfs as well.

${ }^{31}$ Unless otherwise indicated, the following information on students of Heidelberg University is from Heltai (2006).
} 
For example, János Keserúi Dajka (1580-1633), who enrolled at Heidelberg University in 1609 and who was a student of Pareus, became a superintendent (bishop) of the Calvinist church of Transylvania and court chaplain to the ruling prince, Gábor Bethlen. Dajka recommended that his prince send students to Heidelberg University each year. The personal ties between Pareus and Dajka were so close that Pareus dedicated to him the volume Collegiorum theologicorum pars altera (1620), a collection of disputations that he had edited (Heltai, 2006, pp. 65-66). Péter Alvinczi (1570-1634) served as court chaplain, confidant, and political counselor to the princes István Bocskay and Gábor Bethlen (Heltai, 1994). Caspar Boithius (1595-died after 1640) studied in Heidelberg with Gábor Bethlen's support from 1617 to 1620 and later became a linchpin in the relations between the Palatinate and Hungary. Between 1615 and 1660 an unbroken succession of men from Heidelberg served at the court of Gyulafehérvár/Weissenburg and as superintendent (bishop) of Transylvania: János Keserúi Dajka, István Milotai Nyilas, István Geleji Katona, and György Csulai (Heltai, 2006, p. 72).

István Milotai Nyilas (1571-1623) was another court chaplain to Prince Gábor Bethlen for a time and did much to shape the Transylvanian school system. István Geleji Katona (1589-1649), who enrolled at Wittenberg in 1596 and at Heidelberg in 1598, became famous because he was court chaplain to three Transylvanian princes, tutor to István Bethlen (1606-1632) — a nephew of Prince Gábor Bethlen and potential heir to the throne-and superintendent of Transylvania. His Magyar Grammatikatska (Little Hungarian Grammar Book, published in Gyulafehévár in 1645) greatly nurtured the development of Hungary's linguistic culture (see Nagy, 1967, p. 44; Seidel, 2004, pp. 233-236).

Albert Szenczi Molnár (1574-1634), one of his time's most versatile and best known Hungarian scholars, offers an impressive example of high academic mobility and the seminal role of networks, therefore merits somewhat more detailed consideration in this overview (for additional information see Dézsi, 1897; Giebermann, 2005; Szabó, 1999a, 2003; Vásárhelyi, 1985, 1999, 2006, 2014). Molnár left the Calvinist academy of Debrecen at the age of 16 and enrolled at several German universities in the course of time, including Wittenberg (1590), Heidelberg (1592 and 1596), Herborn, Strasbourg, and Altdorf. At the University of Altdorf, he edited the Elementa Grammatica Latinae (Elements of Latin Grammar) and a HungarianLatin-Greek dictionary that was printed in Nuremberg in 1604. The dictionary's high quality and the fact that Latin was the official language in Hungary until the mid-nineteenth century ensured that work's use in Hungary for two-hundred years.

In Altdorf Molnár also worked on his main opus, the Psalterium Hungaricum, the Hungarian translation of the Psalms of David. From 1607 to 1611, he resided in Marburg, where the Calvinist landgrave Moritz von Hessen-Kassel aided him financially. It was there that Molnár once again revised the Hungarian translation of the Bible, published a new translation of the Heidelberg Catechism, and wrote the first solid grammar of the Hungarian language. In Geneva, the bastion of Calvinism, he consulted with the acclaimed Calvinist theologian Theodore Beza. After moving back to Heidelberg from Geneva, he worked primarily with the poet Martin Opitz, whom Gábor Bethlen later called to the academy in Gyulafehérvár. 
In 1614 Molnár went to Hanau briefly, soon thereafter to Amberg, and a year later to Oppenheim. There he worked as the precentor (Kantor) of the grammar school and, from 1617 to 1619 , as its rector. In 1619 he again took up residence in Heidelberg, where in 1622 he was brutalized by troops and lost much of his library when the city fell to troops commanded by Count Tilly (1659-1632), a field marshal commanding forces of the Catholic League during the Thirty Years' War. After fleeing Heidelberg, he worked at the University of Leiden and then made his way back to Hungary. Within a year he went to Hanau via Heidelberg. The counts of Hanau granted the Calvinist refugees asylum at that time. After two years in the town, Molnár resettled in Hungary for good, this time in Transylvania, where Prince Gábor Bethlen maintained him.

Many students from Hungary and Transylvania received scholarships for their studies in other countries. Their patrons attached certain conditions to this help, so the choice of what and where to study did not always lie with the students alone. The patrons of 81 students are known for the years from 1595 to 1621 (Heltai, 2006, p. 69). Gábor Bethlen, for example, sent 17 students to Heidelberg at his own cost beginning in 1614; the Rákóczi family, 8 students. Grants were provided by many other aristocratic families, too-such as Lórántffy, Thököly, Dobó, Bocskay, and Mágocsy (for details see Bernhard, 2015, pp. 529-532) —as well as the minor nobility, middle-class, and towns. The overriding aim of these scholarships was to build an efficient Calvinist ecclesiastical, educational, and administrative structure in Transylvania (Asche, 2004, p. 44). The eminent value attached to educationally motivated migration abroad is apparent from a law forbidding authorities, even the prince himself, to thwart a student's study tour by denying a travel permit (Tonk \& Szabó, 1993).

Unlike Silesian students, a substantial percentage of whom remained in the Electoral Palatinate after completing their studies in Heidelberg, nearly all Hungarian students went back to their homeland as they were obliged to do by their patrons. The students were expected to make the knowledge gained abroad available to the principality, church, or benefactor. These expectations were explicit, as shown by a letter written by Prince Gábor Bethlen to Boithius:

[I]f you are thinking of continuing your studies, we inform you that we are prepared to assume their cost for four years. We desire you to go from Heidelberg to Padua for a year or half a year and from there to Paris, where you will stay half a year and come back to us after your study tour. . . . In order for you to understand our intentions in this context, we wish to advise that you diligently lay the foundations not only of your theological but also of your philosophical knowledge so that we can use your expertise both in God's House and in secular matters as well as in foreign policy or wherever we wish after your return. (Quoted in Ladányi, 1999, p. 216; 2001, p. 136).

This letter documents that the decisions on the location(s), subject(s), duration, and academic degree relating to the recipient's study in a foreign country were heavily swayed by the institutions and aristocratic families financing the venture. Church politics and foreign policy thus also influenced the choice of university at which one was to study. 
Pareus's former students constituted a close network that played a role for a long time not only in the development of the Calvinist church and Hungarian intellectual life but also in the cultural and foreign policy of the Transylvanian princes. Heidelberg University's faculty of theology at that time figured decisively in the training of the Hungarian and particularly the Transylvanian educational elite for more than 20 years. The Hungarian students who had enrolled with the faculty of theology did not confine themselves to studying theology. The core training of future preachers also involved knowledge of philosophy, skill in rhetoric and grammar, and the reading of ancient texts. The students in Heidelberg also came into contact with late-humanist art and literature, tracts on theories of the state, and writings in the natural sciences. They could also supplement these academic studies by learning to dance, fence, and ride.

After resettling back home, the Heidelberg alumni constituted an exceptional stratum of the Hungarian and Transylvanian intellectual elite, one characterized by notable upward social mobility and excellent training (Heltai, 1994, 2006). Many of them kept up written correspondence with thinkers at the centers of the Reformation in the Holy Roman Empire, the Low Countries, England, and Switzerland, cultivating the contact essential for bringing new knowledge into Transylvania (see Seidel, 2004, pp. 227-228). Those who extended their time abroad, such as Albert Szenczi Molnár, endeavored to pave the way for the students newly arriving from Hungary and Transylvania.

\section{Cavalier's Tours (Grand Tours) ${ }^{32}$ by Aristocratic Students}

In Europe of the early seventeenth century, the educational ideal of the nobility altered fundamentally. Chivalric upbringing was thenceforth supplemented by training in literature, natural science, and especially law so as to prepare the nobility for service at court, in the state administration, and in diplomacy (de Ridder-Symoens, 1996, p. 432). As a result, the percentage of aristocrats among the students increased markedly. The largest contingents of aristocrats among students in seventeenthcentury southern Germany were at the University of Ingolstadt and Heidelberg University (Müller, 1984, pp. 38-39). Prominent Hungarian aristocrats who studied in Heidelberg included István Bethlen, who enrolled at Heidelberg University for the 1619-1620 academic year together with three other grandees. Another estimable aristocrat was Miklós (Nikolaus) Bethlen (1642-1716; see below, this section).

\footnotetext{
${ }^{32}$ Cavalier's Tour and Grand Tour are not equivalent. The term Cavalier's Tour is generally used for high-ranking nobility. The term Grand Tour has a broader definition, notably in Anglo-Saxon research, and also includes students of the middle classes. Cavalier's Tours may differ from Grand Tours in the duration of the journey, the assigned tasks that have to be fulfilled during the journey (e.g., diplomatic missions), the means of transportation, accommodations at the destinations (highranking nobles were often invited to stay at courts), and other criteria of social distinction (for details see Leibetseder, 2004, 2013).
} 
Barons Stephan and Nikolaus Thököly of Késmárk, who were from one of Hungary's wealthiest aristocratic families, enrolled at Heidelberg University in 1596 and 1603, respectively. Nobles from the Bornemisza, Barcsay, Újfalvi Katona, und Decius families enrolled there in this period, too.

Unlike the students from the middle and lower strata of society, most young nobles did not intend to acquire occupational training or an academic title during their study outside their country. For Hungary's higher nobility and the wealthiest landowners, studying abroad was often linked with a Cavalier's Tour, which had been very popular throughout Europe since the late sixteenth century. Its purpose was to culminate aristocratic, courtly education; prepare the social elites for their future responsibilities; raise the political status of aristocratic families; and pursue political objectives (for details see Almási, 2014; Black, 1983, 1992; Chaney, 1998; de Ridder-Symoens, 1996; Freller, 2007; Heiss, 2005; Kühnel, 1964; Leibetseder, 2004, 2013; Pánek \& Polívka, 2005; Paravicini, 2005; Schwinges, 2005). Aristocratic students used the Cavalier's Tours to visit various courts, participate in ceremonies there; acquire genteel etiquette, court ritual, and language skills; make political contacts; and conduct confidential, diplomatic missions. The Cavalier's Tour thus served not only the appropriation of knowledge and competence but also "the necessary symbolic distinction" (Paravicini, 2005, p. 667). In the sixteenth and seventeenth centuries the Cavalier's Tour was a must in the education of the higher nobility, tantamount to an initiation into the world of the social and political elite and a staple of cultural transfer (see Heiss, 2005, pp. 218-219; Pánek \& Polívka, 2005, pp. 68-69; Paravicini, 2005, pp. 658-660). The students from the higher nobility were usually accompanied by an experienced tutor (ephorus), who was responsible for the study and all organizational and financial aspects of the journey. This person had to be fluent in foreign languages and, of course, had to enjoy the family's full trust (for details see Garms-Cornides, 2005; Ugry, 2014).

The Cavalier's Tour by Hungarian nobles, depending on their confession, took routes similar to those of the educational migrations embarked on by nonaristocratic students. The Lutherans and Calvinists headed above all to the Protestant regions of the Holy Roman Empire, with Heidelberg being one of the obligatory destinations. ${ }^{33}$ After the outbreak of the Thirty Years' War, the Low Countries became the focus, usually connected with a brief stop in England (for details see Gömöri, 1985), Switzerland, or Paris. The educational journeys of the Catholic nobility usually took the students from those families to universities within the Habsburg empire and were supplemented by trips to Italy (Rome, Bologna, and Padua), Flemish Brabant (Louvain), and France (Paris) (for details see Schindling, 2006).

One can precisely reconstruct the itinerary of Miklós Bethlen's three-year Cavalier's Tour (Fig. 3.8) from his rich, essayistic memoirs (Bethlen, 1955), several editions of which have been published because of their high literary and historical value. Bethlen registered at Heidelberg University in 1661, studying rhetoric,

\footnotetext{
${ }^{33}$ If a university was located in a town or city in which a court resided, such as Heidelberg, the activities at court and at the university could be linked quite well (Paravicini, 2005, p. 663).
} 


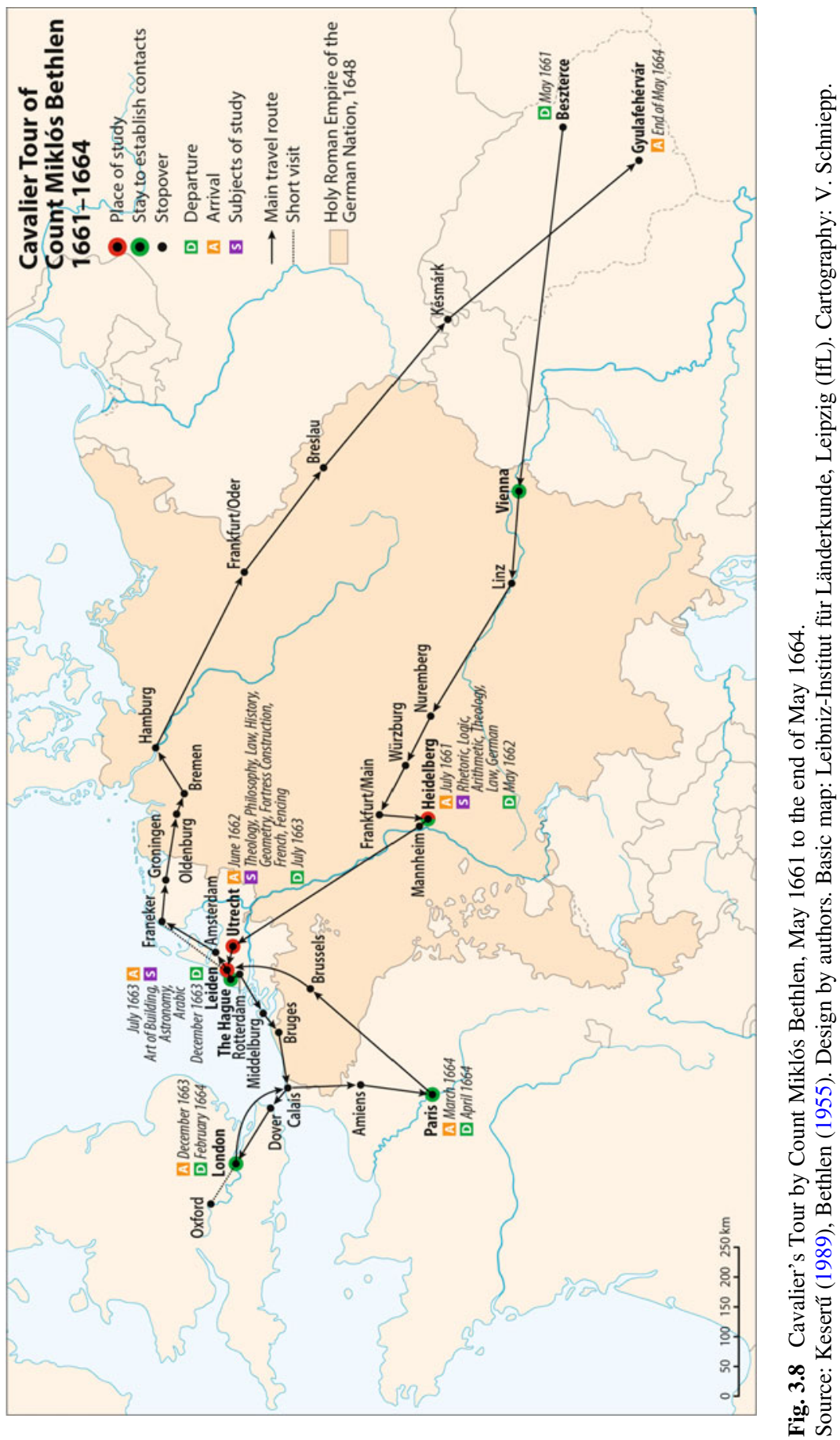


arithmetic, logic, theology, and law during his 11 months there. In his memoirs he mentioned receiving frequent invitations from Prince Elector Karl Ludwig to hunt and dine in Heidelberg (Bethlen, 1955; Vékás, 2001, pp. 140-141). ${ }^{34}$ The elaborately ornamented entry of Bethlen's enrollment on the first page of the 1661 registry (Fig. 3.9) documents what Schwinges (2005, pp. 357-360) described as the ubiquitous rankings and favoritism of the nobility at the universities. ${ }^{35}$ Differences in status were documented even for registration purposes, for the names in the registry were not listed in chronological order of the entry but rather according to the social hierarchy of the students, with the nobles placed first (Fig. 3.9). Then came the church canons, the other dignitaries and well-to-do members of the bourgeoisie, and, lastly, the pauperes, or students of little or no means (pp. 359-360).

After Heidelberg, Miklós Bethlen spent a year at the University of Utrecht and half a year at the University of Leiden, visiting Oxford and Paris as well. As Fig. 3.8 shows, Miklós Bethlen covered the distance from Paris back to Transylvania fairly quickly. He lingered only one or two days in the sizeable cities, less time than he had spent when going in the other direction. The reason for his haste was that he had been entrusted with a letter from the French king and wanted to deliver it to the Prince in Transylvania as soon as possible. Miklós Bethlen later became one of Transylvania's leading politicians and was charged with important diplomatic missions (Vékás, 2001, p. 140).

Figure 3.11 shows the Cavalier's Tour by Pál Teleki, the son of Mihály Teleki (1534-1690), who determined Transylvanian foreign policy as field marshal and chancellor for three decades, during which he acquired an immense fortune and gigantic estates. Pál Teleki's mother (Mihály Teleki's widow) and his professors in the Nagyenyed Academy had prepared his study and travels outside Hungary carefully and kept up a lively correspondence with him during his absence. He received a remarkable number of suggestions and basic instructions from Ferenc Pápai Páriz, a famous Heidelberg alumnus who at that time was the Teleki family's physician and a professor at the academy. The Transylvanian professors occasionally asked Teleki to buy various books, which were then to be sent to Nagyenyed. The only reason Teleki did not visit Heidelberg was that the city and its university buildings had been obliterated in 1693 during the War of Palatine Succession (the Nine Years' War, 1688-1697; for details about the destruction, see Rotzoll, 2012). The route that Pál Teleki took during his tour is traceable with the aid of his published private correspondence and his Album amicorum, which contains about 220 entries of his interlocutors, mostly from the professors he visited abroad and

\footnotetext{
${ }^{34}$ Bethlen's memoires also include humorous anecdotes about the customs of the hunt and about life at court. As a farewell present, the Prince Elector gave him two valuable pistols with ebony grips, which Bethlen appraised as the best he had ever owned (Bethlen, 1955).

${ }^{35}$ Unlike the academies for knights, which concentrated solely on training the nobility (Müller, 1984, p. 35), the universities accepted everyone, but the feudal distinctions between the status or rank of the families of origin were displayed at every turn, as in registries, official scholarly debates, worship services, processions, and assigned seating in lecture halls (Schwinges, 1986, pp. 346-351; 2005, pp. 357-359).
} 


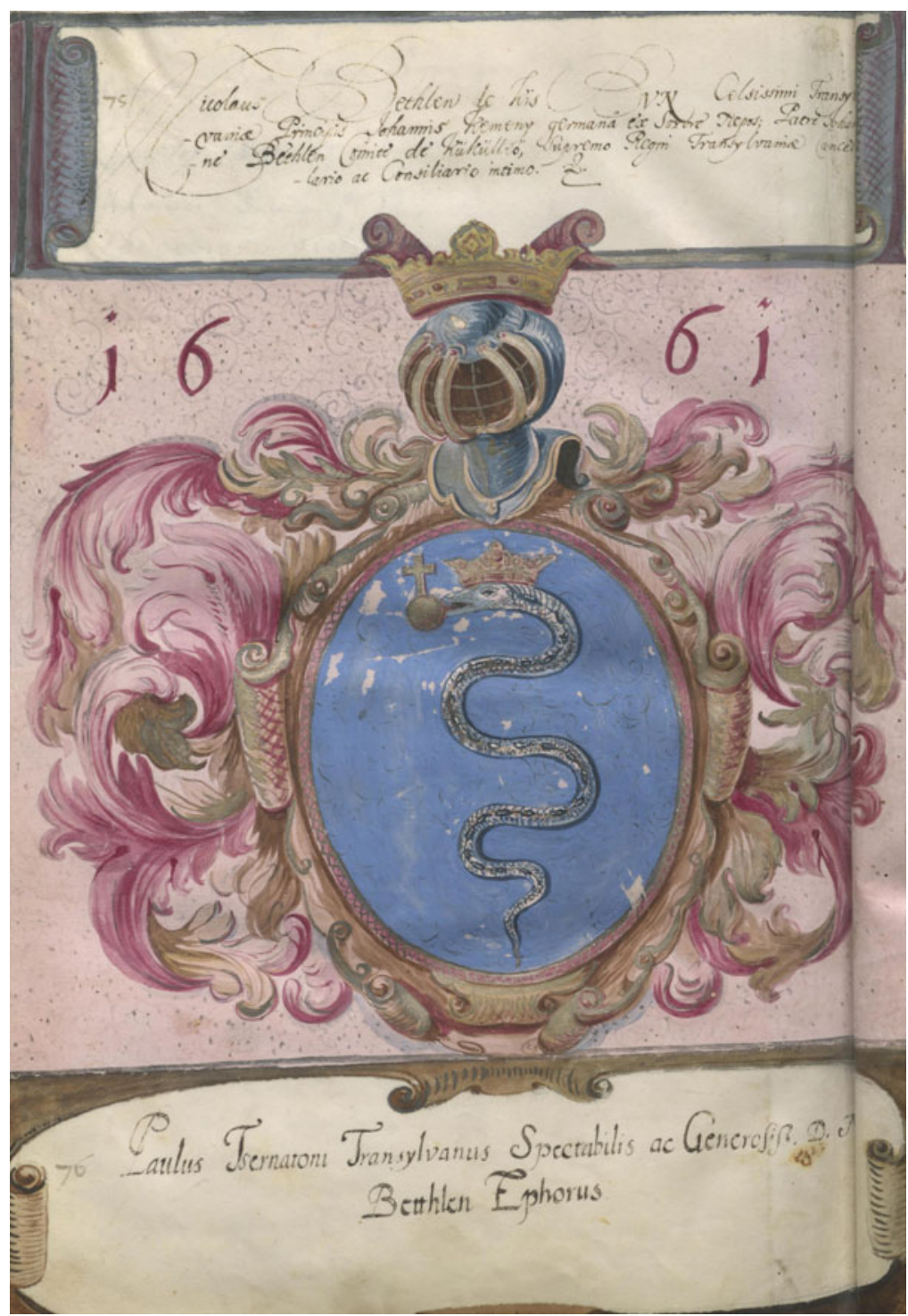

Fig. 3.9 Entry on Miklós (Nikolaus) Bethlen and his ephorus, Paulus Tsernatoni, first page of the Heidelberg University registry of 1661.

Source: Registry of 1661. Heidelberg University Archives. UAH, M 4 (1579-1662), fol. 184v. Reprinted with permission. 
from fellow Hungarian students. ${ }^{36}$ These sources are a trove of interesting information, but unfortunately they reveal little about what he actually studied (Keserú, 1989).

At least the students who were somewhat well-off were keen on acquiring and bringing home newly published books during their journeys, or were even commissioned to do so by their benefactors. The main private and ecclesiastical libraries of Hungary and Transylvania received most of their books through students who had studied abroad. Borne by Hungarian students returning home, the teachings of Descartes and Newton, the ideas of the European Enlightenment, the results of experimental physics and chemistry, and modern mathematics swiftly spread to Hungary (Győri, 2010, p. 254). Pál Ceglédi Szabó (1590?-1649), the Calvinist superintendent of Transdanubia (the part of Hungary west of the Danube river), had a private library of 232 books, of which 171 had been acquired abroad and 38 printed in Heidelberg, where Ceglédi Szabó had enrolled in 1613 (Zvara, 2012). This collection was not even among the largest. In Transylvania and Hungary of the late sixteenth century, there were several tens of thousands of printed books, chiefly theological works. The most often read author was Philipp Melanchthon, but the literature by ancient Greek and Roman writers and by contemporary humanists were also widely known, especially Aristotle, Erasmus, Ramus, Justus Lipsius, and Boccaccio (Köpeczi, 1990).

The scientific and cultural relations of the intellectual elites of Hungary and Transylvania were thus oriented at that time almost solely to Europe's Latin heritage. The students from that part of society mostly avoided educational tours to the Romanian princedoms, which were perceived as being economically and culturally underdeveloped, ${ }^{37}$ dominated by the Greek Orthodox religion, and subject to a hostile, pagan Ottoman empire (Kármán, 2006). Nevertheless, certain Transylvanian cities, above all Kolozsvár (Klausenburg, today's Cluj-Napoca) and Brassó (Kronstadt, today's Braşov), were foci of some cultural exchange between the Romanian-, Hungarian-, and German-speaking populations in the sixteenth and seventeenth centuries (for details see Binder, 1975; Huttmann, 1975). Likewise, few Romanians studied at foreign universities before the nineteenth century. Most Romanians were Greek Orthodox, and they trained their future priests in their own

\footnotetext{
${ }^{36}$ An Album amicorum may contain diaries, notes on the journey, and a description of it. The handwritten mementos are occasionally accompanied by epigraphs by friends and guests, designs or, especially in earlier centuries, painted coats of arms.

${ }^{37}$ Brenner (1989), Gunst (1989), Stokes (1989), and many others discuss the historical origins of backwardness in some parts of eastern Europe. Legal structures, the centralization of state power, the structure of feudal society, the density and economic role of cities, the harshness and duration of serfdom, and precapitalistic property relations - all these factors bearing on economic evolution and societal change differed between western and eastern Europe.
} 
seminaries, not at universities (Offner, 2006, p. 293). ${ }^{38}$ The eastern and southern frontiers of Transylvania along the Carpathian mountains were thus a relatively sharp cultural divide and an effective barrier to knowledge transfer, particularly the circulation of books; the diffusion of late Humanism, the Enlightenment, and literacy; and the emergence of modern administration in the territories.

\section{Foreign Policy Interests of the Transylvanian Princes in the Choice of Where Their Subjects Studied}

After Prince Gábor Bethlen assumed power in Transylvania in 1613, many Hungarian Calvinists who later became famous and politically influential studied in Heidelberg, with the maximum annual enrollment of Hungarian and Transylvanian students ranging from 9 to 16 from 1614 to 1620 (see Teutsch, 1872, pp. 186-188). This fact owed partly to Heidelberg University's academic appeal, but politics, too, played a part (Csohány, 1994-1995). One of the reasons that Prince Gábor Bethlen sought close cultural and political relations with the Prince Elector in Heidelberg was that Heidelberg at the time was a center of the anti-Habsburg alliance of Protestant princedoms. Gábor Bethlen wanted to join it so as to stand his ground against Habsburgs and Ottomans alike. Both he and his successor, Prince György Rákóczi I (1593-1648), intensely cultivated the links to these Protestant princedoms through students who had studied in Heidelberg. Intense written correspondence between Pareus and Gábor Bethlen commenced in 1616 (Heltai, 2006, p. 73).

The long-smoldering conflict between the Protestant Union (created in 1608) and the Catholic League (created in 1609) finally ignited when, against all advice, Prince Elector Friedrich V had himself elected King of Bohemia in 1618 (for details see Pánek, 2003). This royal dignity had been offered to Gábor Bethlen and other princes as well, but they had declined because they could imagine the reaction of the Habsburgs. Friedrich's election, which the Habsburg took as an affront, triggered the Battle of White Mountain (November 8, 1620) and the subsequent rout of the Protestant army — the outbreak of the Thirty Years' War. With Heidelberg being the key political center of the Protestant Union, the city and many other settlements in the Electoral Palatinate were ravaged in the war.

With the consent of the Sublime Porte, Gábor Bethlen intervened on religious and political grounds in three field campaigns against the Habsburgs during the Thirty Years' War. His considerable military achievements and diplomatic efforts met with only moderate success, however. Contrary to all initial expectations of the Protestant powers, Habsburg imperial power was not destroyed. But Bethlen did manage to

\footnotetext{
${ }^{38}$ This preference changed in the nineteenth century when the University of Leipzig, for instance, "spearheaded the training of Romanian intellectuals abroad" (Heitmann, 1975, p. 124). The famous Romanian linguist Sextil Puşcariu from Kronstadt was one of the students at the Romanian Language Institute in Leipzig from 1895 to 1899.
} 
ensure that religious freedom and the feudal constitution of Hungary stayed intact and that the Habsburg attempts at centralization failed. By joining the Haag alliance of Great Britain, Denmark, and the Low Countries through the Treaty of Westminster in 1626, he strengthened the international recognition of Transylvania's sovereignty (for details on the complicated diplomatic relations between Transylvania and the other Protestant countries during the Thirty Years' War, see Csohány, 1994-1995, and Kármán, 2013; on Bethlen's foreign policy, see Czettler, 1980-1981, and Schmidt-Rösler, 2006).

\section{Impacts of the Thirty Years' War (1618-1648) and the War of Palatine Succession (1688-1697) on the Mobility of Hungarian Students}

Heidelberg University's intellectual golden age and the institution's academic relations with Hungary and Transylvania abruptly ended during the Thirty Years' War when the town fell to Catholic troops in 1622. Many professors fled, and Heidelberg's famous Bibliotheca Palatina was taken to the Vatican as war booty (Effinger \& Zimmermann, 2012; Meusburger, 2012; Neumaier, 2012a; Rotzoll, 2012). The professors remaining in Heidelberg were dismissed by the Bavarian occupation authorities in 1626, and Heidelberg University did not reopen until 1628 - as a Jesuit university. During the Swedish occupation of the Palatinate (1632-1634), the Jesuit university in Heidelberg was dissolved, and the attempt was made to reestablish a Lutheran university. But Heidelberg was recaptured by the Bavarians, who reinstituted the Jesuit university, though teaching did not resume (Wolgast, 1986). With this demise of Heidelberg University, the students from Hungary and Transylvania gravitated primarily to universities in the Low Countries and England. Between 1623 and 1632 the Universities of Franeker and Leiden in the Low Countries, joined later by the newly founded Universities of Groningen, Amsterdam, Utrecht, and Harderwijk, attracted many students from Hungary and Transylvania (Bozzay, 2010, 2014; Eredics, 2008; Hotson, 2008; Murdock, 2000). Between 1621 and 1631, 52 Hungarian students attended the University of Leiden, and 66 attended the University of Franeker. Between 1631 and 1651, 190 Hungarian students were at Leiden and 200 at Franeker (Bernhard, 2015, p. 482).

In the seventeenth and eighteenth centuries more than $25 \%$ of all Hungarians and Transylvanians studying abroad were enrolled in the Low Countries, with the University of Franeker in Frisia accounting for approximately $40 \%$ of that group ${ }^{39}$ (Bozzay, 2010, p. 215). The early predilection for the Universities of Franeker and Leiden was no coincidence. After the fall of Heidelberg, the renowned Heidelberg professor of the Old Testament, Abraham Scultetus (1566-1624), moved to the Low Countries, where he was exceptionally engaged with the University of Franeker.

\footnotetext{
${ }^{39}$ The University of Franeker was closed in 1811.
} 
Scultetus helped Hungarian students a great deal and wrote them recommendations to pave their way to universities in the Low Countries. Albert Szenczi Molnár, too, was active in Leiden after fleeing from Heidelberg (Eredics, 2008). Johann Heinrich Alting (1583-1644), who was probably second only to Pareus in the number of disputations over which he had presided at Heidelberg University, taught in Groningen from 1627 to 1644 (see Nagy, 1967, p. 44). The professors who had migrated from Heidelberg were not alone in their efforts in Franeker and Leiden. Eredics (2008) found that the two towns also had several Dutch and English professors who were highly involved on behalf of Hungarian students and had major intellectual impact on them. Clearly, the place at which to study was a choice carefully made, and despite the enormous distances between locations many students did not find that moving to another university was detrimental to their educational career or that it was like leaping into the unknown (Irrgang, 2003, p. 67). Existing networks, ties between compatriots, and letters of recommendation from professors and territorial lords reduced the effect that one might expect vast spatial distances to have had on the choice of where to study. The decisive thing was "social proximity," not spatial distance: "Academic migration never dissolves existing relations; it is what really brings them into play for a person's career" (p. 67).

After the Thirty Years' War ended in 1648, Heidelberg University stayed closed for four years. It was not dissolved, but there was no longer any teaching there. Not until 1652 did the university successfully reopen, this time as a Calvinist institution again. Just 36 years later, however, the War of Palatine Succession broke out, a conflict during which the city of Heidelberg, all its university buildings, as well as numerous nearby towns and villages were utterly demolished under the scorchedearth policy of French troops (Musall \& Scheuerbrandt, 1980, pp. 8-12). By 1693, not a single inhabitable building had survived in Heidelberg. The university's faculty members withdrew first to Frankfurt am Main, then in 1698 to Weinheim. The professors were able to return to Heidelberg in early 1700, but lectures did not resume for another four years. The destruction of the city, the wartime hiatuses of teaching, and the multiple forced changes of confession among the Heidelberg professors had blighted the lure of the university (Neumaier, 2012a, Rotzoll, 2012).

The registries of Heidelberg University have gaps due particularly to these wars and other disasters, ${ }^{40}$ but other sources show that students from Hungary and Transylvania were studying at Heidelberg University in the decades after the Thirty Years' War as well. In addition to the aforementioned Miklós Bethlen, who registered at Heidelberg University in 1661, there was Ferenc Pápal Páriz (1649-1716), who studied at the Universities of Frankfurt on the Oder, Marburg, Heidelberg (where he registered in 1672), and Basle. He earned his doctorate in philosophy and theology at Heidelberg. He was even offered a chair at Heidelberg University

\footnotetext{
${ }^{40}$ No students were enrolled at Heidelberg University from 1632 to 1652 . Teaching was suspended from 1642 to 1652 and from 1693 to 1703 . The registries for the years from 1663 to 1689 are missing (lost probably in 1693). The registries of the theological faculty (Toepke, 1886, Appendix V, pp. 545-585) bear names only up to 1685, even then with gaps.
} 
because of his prodigious achievements, but he wished to earn a doctorate in medicine in Basle, where he became a highly acclaimed assessor of medicine and was even granted the honor of delivering the address commemorating the famous professor Johannes Henricus Glaserus in 1675, with the text later being published in Latin and Hungarian many times (Vékás, 2001, p. 141). In 1677 Páriz became the personal physician to Ana Apafi-Bornemisza, the wife of Transylvania's ruling prince. From 1680 to 1716, Páriz was professor of Greek, physics, and logic at the academy in Nagyenyed and contributed much to the Cavalier's Tour by his aristocratic student Pál Teleki (Fig. 3.10). Páriz's Latin-Hungarian and Hungarian-Latin dictionaries, which impressively expanded the work by Albert Szenczi Molnár, were published in 1708 after nearly 20 years of preparation and were reprinted on several occasions. Páriz also became known through the books Pax animae (Peace of the Soul), Pax corporis (Peace of the Body), Pax aulae (Peace of the Court), and Pax sepulchri (Peace of the Grave), which were published in Kolozsvár. The volume of the greatest consequence was Pax corporis, written in Hungarian, in which he described a hundred different kinds of diseases and recommended various therapies. He based the other three books largely on existing publications. Páriz made a name for himself as a church historian, too. His Rudus redivivum (1684) described the history of the Protestant church.

Student mobility diminished for various reasons throughout Europe in the eighteenth century (for details see de Ridder-Symoens, 1996; Schwinges, 1986). One was the rise of mercantilist ideology (e.g., the state as an economic actor, state intervention in the economy, and bans on the emigration of highly skilled laborers). Another was the Enlightenment's cherished idea of education's utility (and the mercantilist corollary that the benefits of education were intended to be reaped by one's own territory, not drained through emigration). A third reason undercutting student mobility in the 1700 s was the increasing territorialization and confessionalization of universities. A final factor that henceforth made study in a foreign country no longer seem as advantageous as it had been was the absolutist state's escalating need for control (de Ridder-Symoens, 1996; Hammerstein, 1995, 1996; Stagl, 1995). The university and the free movement and settlement of students were subordinated to the interests of the absolutist state of the eighteenth century (Schwinges, 1986, p. 229). For anyone seeking a position in the church or state administration, some territorial rulers at that time made it a requirement to study at the university they had created in their own lands, and they deliberately limited study elsewhere by their subjects. Other rulers even expressly forbade study at certain foreign universities (for details see de Ridder-Symoens, 1996, pp. 437-439, 443). ${ }^{41}$

\footnotetext{
${ }^{41}$ Such policies therefore heavily restricted the universality of academic degrees, which since the mid-thirteenth century had made examinations conducted at one university valid at all other universities and had established the parity of the academic degrees that they conferred (Kintzinger, 2012, p. 309).
} 


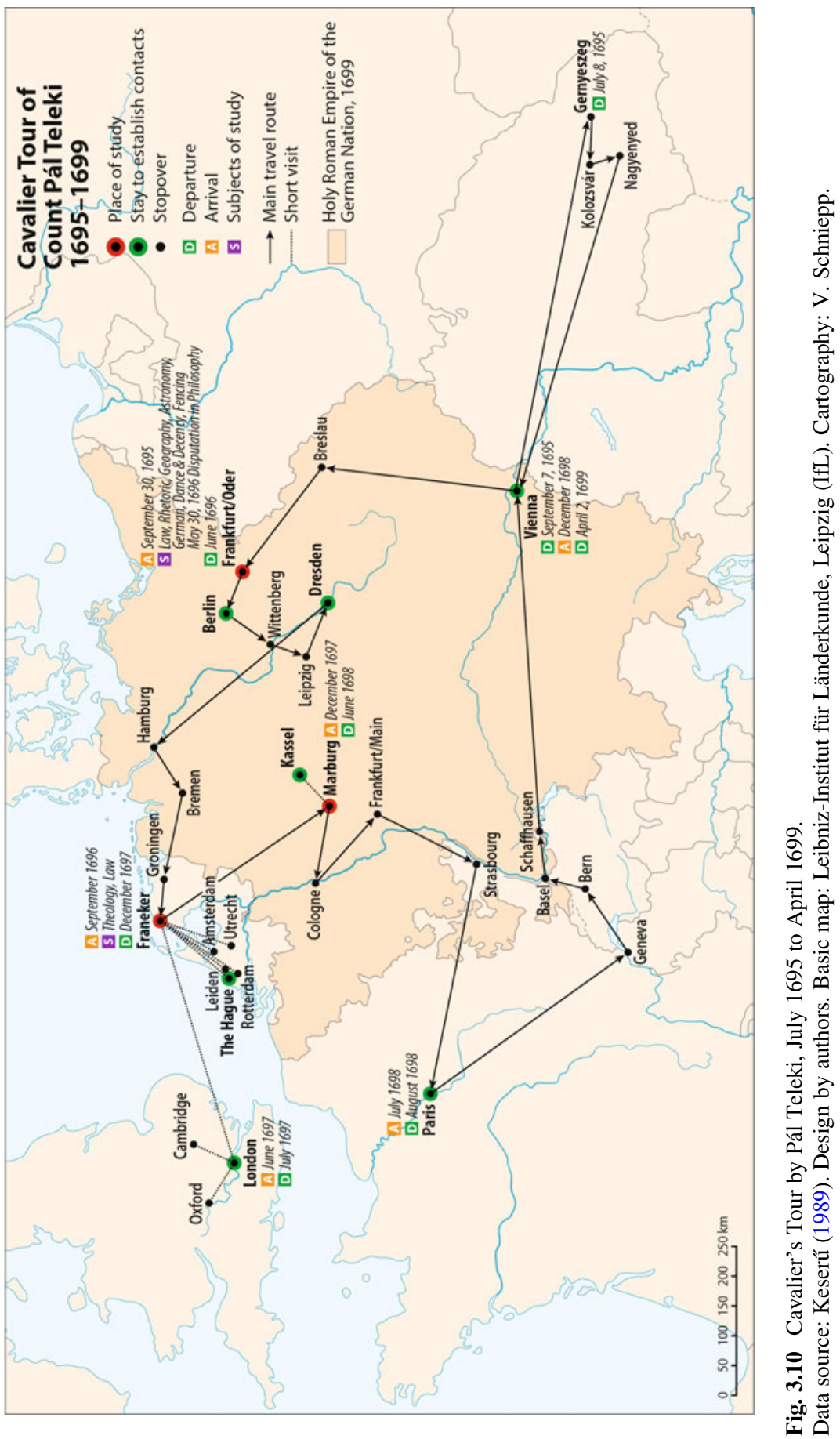


The number of Hungarian students at Germany's Protestant universities dwindled in the seventeenth and eighteenth centuries also because of the re-Catholization of western and northern Hungary. Cardinal Péter Pázmány succeeded in reconverting 30 of the foremost families of the higher Hungarian nobility. He was supported by the court in Vienna, which granted privileges, honors, and high offices solely to candidates nominated by Pázmány (Bucsay, 1977, p. 166). Hungary’s Catholic students thenceforth tended to opt especially for the closer, Catholic universities in Graz, Vienna, and Nagyszombat. The University of Graz had been under Jesuit influence since its founding in 1586. The University of Vienna came under Jesuits leadership in 1624, as did the university that Pázmány founded in Nagyszombat in 1635 (Andritsch, 1965, p. 2; Barta, 1937; Fata, 2004; Fata \& Schindling, 2006). In the late sixteenth and first decades of the seventeenth century, most of Hungary's Catholic elite was trained at the University of Graz (Andritsch, 1965, p. 6).

As of 1725 the flow of Hungarian students to Germany abated also because of the Habsburg government's attempt to control study abroad by requiring them to possess a valid passport. As of 1748, these documents were valid for only one year (Gönczi, 2006, p. 177; Ladányi, 2001, p. 136). In the second half of the eighteenth and early nineteenth century, the Habsburg government tried to restrict study abroad by Hungarian Protestants - and the infiltration of unwanted ideas in general - by repeatedly banning attendance at specific universities, particularly Prussian ones (1756-1759, 1763-1766, 1804, 1818-1819) (Kardos, 2000, pp. 47-50; Rasche, 2006, pp. 197-204; Varga, 2001, p. 180). In 1759 Empress Maria Theresia forbade Hungary's Protestant students to collect any domestic contributions for their studies (Bozzay, 2010, p. 216).

\section{The Decline of Heidelberg University in the Eighteenth Century}

Except for the brief interludes from 1750 to 1756 and 1780 to 1783 , attendance at Heidelberg University by students from the Carpathian Basin was relatively rare in the final decades of the eighteenth century (Fig. 3.7). The intellectual caliber of that university had deteriorated badly; ${ }^{42}$ teaching was highly regimented and uninnovative; and the political authorities interfered with the recruitment of professors, favoring "native children" (Mussgnug, 2003, p. 131; Neumaier, 2012a, p. 75; Wolgast, 1986, pp. 5, 84).

\footnotetext{
${ }^{42}$ Friedrich Gedike, visiting the German universities on behalf of Prussian King Frederick William II, for example, wrote of Heidelberg in 1789: "Everything that I saw and heard convinced me that this university is insignificant" (cited in Wolgast, 1986, p. 84). In 1798 the rector of the university reported that "Heidelberg University exhibits the infirmities of advanced old age: dullness and inactivity" (cited in Wolgast, 1986, p. 85). In 1798 the financial plight of the university prompted a government commission to conclude that the institution had to be deemed "a terminally ill patient... whom it would be best to allow to die in peace" (cited in Mussgnug, 2003, p. 131).
} 
The erosion of Heidelberg's importance also stemmed from clashes between Prince Elector Carl Philipp (1661-1742) and the city's inhabitants. The conflicts had prompted him to move his court to Mannheim in 1720 and leave Heidelberg bereft of meaningful political, cultural, and economic functions and largely uninteresting. When Napoleon occupied the territories west of the Rhine in 1794, Heidelberg University lost most of what it owned, for its assets had lain chiefly beyond what had just become the new frontier (Merkel, 2012, p. 47). With its economic existence jeopardized, the university fell several months behind in paying the salaries of the professors (Wolgast, 1986, pp. 83-84) and was facing closure. ${ }^{43}$

Halle, Göttingen, and Leipzig were Germany's most modern universities in the eighteenth century, so most of the students from Hungary and Transylvania went there. As of about 1750, the University of Göttingen was one of Europe's best universities, known for its outstanding professors. It also served many other universities as a model of reform. In the early nineteenth century, Göttingen's university library contained approximately ten times the number of volumes as that of Harvard University, the largest library in the United States at that time (Honeck \& Meusburger, 2012). It is therefore not surprising that Göttingen became the leading university for Hungarian students as well in the second half of the eighteenth century (Gönczi, 2006). ${ }^{44}$

\section{The Second Intellectual Heyday of Academic Relations between Heidelberg and Hungary: The Nineteenth and Early Twentieth Centuries}

\section{Reasons for the Renewed Flood of Hungarian Students to Heidelberg}

In 1803, after the Electoral Palatinate had been dissolved by Napoleon and Heidelberg attached to the Margraviate (Grand Duchy as of 1806) of Baden, serious reforms ushered in Heidelberg University's reascendance in the following decades, culminating in a second phase of academic glory from the 1850s to the outbreak of World War I (Hübner, 2010; Meusburger, 2012; Meusburger \& Schuch, 2010, 2012; Wolgast, 1986, 1987). In the mid-nineteenth century no German province spent a

\footnotetext{
${ }^{43}$ The crisis hit many universities, as did Napoleon's move to shut down German universities that he regarded as politically unreliable. Between 1786 and 1818 these two issues resulted in the closure of 20 of the 42 universities existing on the territory of the Holy Roman Empire of the German Nation (Eulenburg, 1904; Meusburger, 2012, p. 21).

${ }^{44}$ Baron Sándor Prónay, the curator general of the Hungarian Evangelical churches and schools, once expressed this sentiment in a letter of recommendation: "Göttingen never ceases being Hungary's teacher - the major source of our enlightenment and culture" (quoted in Gönczi, 2006, p. 176).
} 
more sizeable share of its budget on universities and gave them more per-capita assistance than the Grand Duchy of Baden did (Pfetsch, 1974). But there were several other reasons for Heidelberg university's resurgent academic stature (for details see Engehausen, 2012; Honeck \& Meusburger, 2012; Meusburger \& Schuch, 2010; Wolgast, 1987).

Heidelberg University's rapidly rising scientific and intellectual appeal did not immediately open a floodgate of students from Hungary, however (for details see Fricke, Koch, Meusburger, \& Preusker, 2012). In the initial decades of the nineteenth century, the Napoleonic wars, the Holy Alliance's Carlsbad Decrees of 1819 (which strengthened control over and censorship of universities and the press), the restrictions imposed during the years preceding the revolution of March 1848 (Vormärz), ${ }^{45}$ and the events of the 1848-1849 revolution itself (for detail see Engehausen, 2012) continued to make study in Germany appear unworthwhile. Moreover, travel restrictions kept Hungarian students from going to Germany from 1819 until 1827 (Szögi, 2006, p. 391), so Germany's universities together registered only two to six Hungarian students per year (Szögi, 2001, p. 27, 2006, p. 391).

The measures introduced by István Széchenyi (1791-1860) and others in the 1820 s and 1830s to reform and modernize Hungary's society and economy led to a rise in the number of Hungarian students in Germany after 1834. However, this trend ended when the Habsburgs and the Russian Czar put down the Hungarian revolution of 1848. Hungarian students did not start flocking to Germany until the AustroHungarian Compromise of 1867, which restored Hungary's political and economic independence within the Danube monarchy, facilitated numerous reforms and modernization in Hungary, and led to massive migration to Budapest. Until World War I it also sparked uncommonly dynamic development, which was also reflected by the number of Hungarian students in Germany (Table 3.1, Fig. 3.11). Szögi (2004) pointed out that Hungary sent more students to Germany between 1867 and 1919

Table 3.1 Hungarians enrolled at German universities

\begin{tabular}{lc}
\hline Period & Number registered \\
\hline $1694-1789$ & 3,944 \\
$1789-1819$ & 1,371 \\
$1819-1849$ & 934 \\
$1849-1867$ & 1,275 \\
$1867-1890$ & 3,277 \\
$1890-1919$ & 7,691 \\
Total & 18,492 \\
\hline
\end{tabular}

Source: Szögi (2006, p. 389).

\footnotetext{
${ }^{45}$ To most authors the term Vormärz means the period between 1830 (the July revolution in France) and March 1848. Some writers, however, understand it to include only the background directly related to the Revolution of 1848 - the years as of 1840 .
} 
- Hungarian students enrolled in Heidelberg 1789-1919 by five-year periods

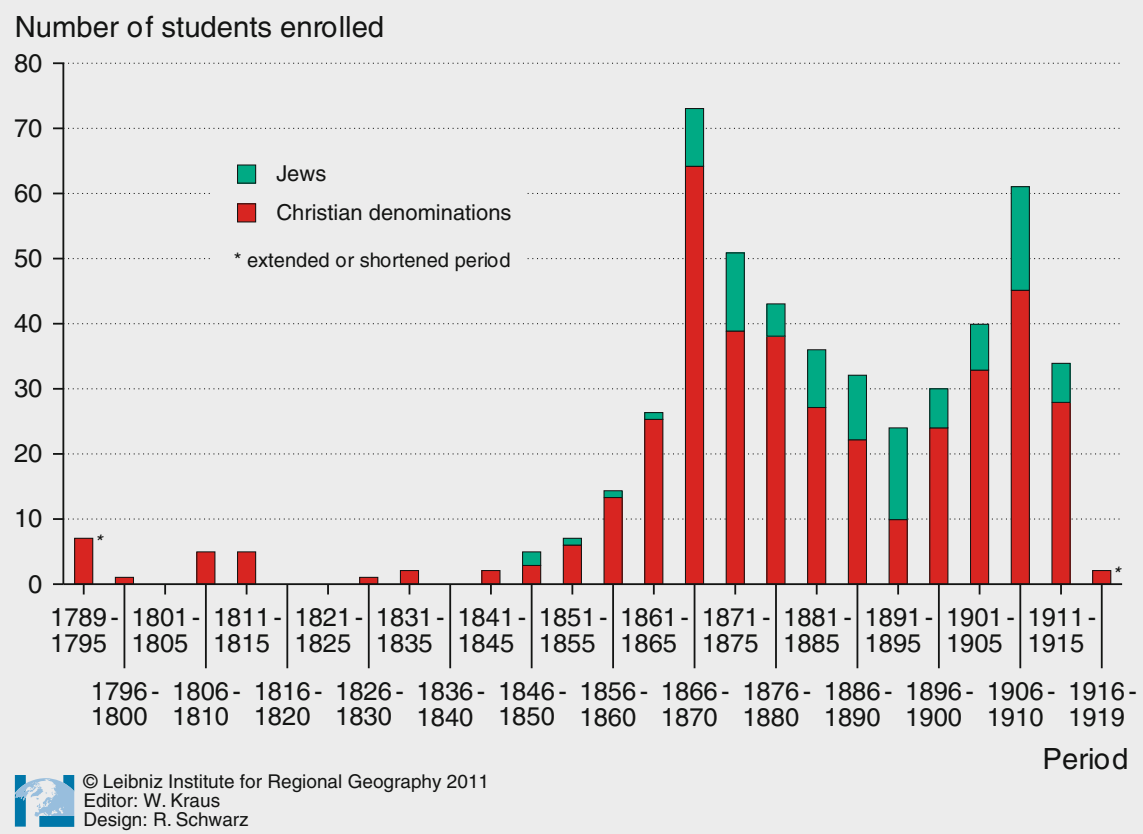

Fig. 3.11 Hungarians enrolled at Heidelberg University, 1789-1919, by five year periods. Source: Meusburger and Probáld (2012, p. 304). Reprinted with permission.

than did the Scandinavian countries (whose combined number of inhabitants was similar to Hungary's), although language affiliation and geographic distance lead one to expect the opposite.

Between 1876 and 1892 the number of Hungarians studying in Germany dipped again because of the swift expansion of the Hungarian university system, but it recovered after 1893 to swell into a second, even bigger wave that lasted until 1913 (see Szögi, 2001, pp. 27-28). However, the rise in the number of students coming to Heidelberg from Hungary (Fig. 3.11) differed from that of the same group at other German universities. In Heidelberg, the first peak of Hungarian students arriving after the Compromise of 1867 was far higher than at other German universities. But the second peak in Heidelberg-between 1906 and 1910 — was much lower than in Germany at large because in that phase the metropolises Berlin and Munich were the most coveted locations for the students from Hungary.

The strong influx of Hungarian students at German universities between 1867 and 1919 had several reasons. First, the political, economic, and cultural upheaval and the profound economic and social processes of modernization occasioned in Hungary by the Comprise of 1867 coincided with a phase during which some German 
universities (including Heidelberg) were among the world's best (Hübner, 2010; Meusburger \& Schuch, 2010, 2012; Wolgast 1986, 1987). In Hungary this reputation meant that an academic degree from a German university was exceedingly valuable.

Second, Hungarian had only recently been introduced into higher education for purposes of instruction, and many Hungarian citizens at that time were not yet adequately skilled in the language. German, by contrast, was fairly common as vernacular or as a second language of the elites and the urban population, notably among the Jews and the German minorities in Hungary. Upper-middle-class Jews in particular cultivated close ties to the German language and culture after $1867 .{ }^{46}$ Szögi (2006) has estimated that around one third of the Hungarian nationals studying in Germany between 1789 and 1919 spoke German as a mother tongue, for several Hungarian towns, wide swathes of Transylvania, the Zips region, the Banat, and Bačka had German minorities. ${ }^{47}$ In 1856, 56.4\% of the population in Buda, Óbuda, and Pest, which were united to form Budapest in 1873, still stated they spoke German in their daily lives. Only $36.6 \%$ said they spoke Hungarian; 5\%, Slovakian; and $1.7 \%$, Serbian. In 1890 , by contrast, $67.1 \%$ stated they spoke Hungarian in everyday life, whereas only $23.7 \%$ still claimed to use German anymore (Gantner, 2006, p. 461; Varga, 2003, pp. 173-174).

Third, passports were not yet required in most of Europe at that time. They were not introduced as an official document in Hungary until 1903 and were required only for visits to Romania, Serbia, the Ottoman empire, and the Russian empire (Bencsik, 2002). Fourth, the currency system, which was based on the gold standard, guaranteed the convertibility of national currencies and the stability of exchange rates. Fifth, expansion of the railroad network reached its zenith before World War I, making travel faster and cheaper than ever.

The sixth and probably decisive reason for the high numbers of Hungarian students at German universities for half a century after 1867 was that a colossal expansion of industry and services in Hungary caused a leap in the country's demand for highly educated labor. Between 1867 and 1914 the Hungarian economy grew at an annual rate of $3.5 \%$, and national income quadrupled. With only three or four continental European countries surpassing that pace, Hungary was quickly catching up to Europe's highly developed regions (Bodrogi \& Galántai, 2013). After the nobility's

\footnotetext{
${ }^{46}$ Theodor Herzl (1860-1904), one of Zionism's founders, spoke German at home. Like many other Jews, he had attended Budapest's upper-secondary Lutheran school created in 1872, which stressed the acquisition of the German language and culture and which was known for its liberal education (Gantner, 2006, pp. 461-462).

${ }^{47}$ The first two waves of German-speaking immigrants arrived in the Carpathian Basin in the eleventh and thirteenth centuries, mainly in some mining towns of Upper Hungary and in southern Transylvania. The third and largest period of immigration occurred between 1711 and 1780 because of a resettlement policy pursued by the Habsburgs after expulsion of the Ottomans from devastated and depopulated Hungarian territory (for details see Anderegg, 2000; Fata, 2014). In the late eighteenth century the Kingdom of Hungary had more than one million German-speaking inhabitants; at the end of World War I, almost two million.
} 
class privileges were abolished in Hungary in 1848 and suffrage was tied to an educational or means census, people could convert schooling into political capital. This possibility enhanced the attraction of formal education as a way to rise into the influential elite, with a foreign academic degree having exceptionally high status.

The Hungarian government in those years put priority on building an effective, modern educational system. After futile earlier attempts ${ }^{48}$ to introduce universal compulsory education, the government finally succeeded in doing so by promulgating Act XXXVIII of 1868. Only 48\% of the country's 6- to 12-year-olds attended a grammar school in 1868, but by 1913 the figure had risen to $93 \%$. Illiteracy among persons older than 7 years declined from $61 \%$ to $31 \%$ between 1870 and 1910 . In the latter year $3 \%$ to $4 \%$ of the boys born in an age cohort spanning a single year attended a Gymnasium, completion of which entitled them to attend a university or other form of tertiary education. Between 1867 and 1917, the number of students in institutions of higher learning climbed from 4,830 to 18,033 (Pukánszky \& Németh, 1996), a quadrupling that owed partly to the expansion of several universities and the founding of new ones.

From 1635 to 1871, Hungary had only one university, the Catholic university in Nagyszombat. It was transferred first to Buda in 1777 as the Hungarian state university, then to Pest in 1784. In 1871 the Technical University was added in Buda. These two institutions were among the largest in Europe and were highly regarded for their academic caliber. Other universities were founded in Kolozsvár (1872), Pozsony (1912), and Debrecen (1914).

The intensity of study in foreign countries and the choice of where to study there also depended on the Hungarian population's ethnic affiliations. Act II of 1844 abolished Latin as the official language in Hungary, replacing it with Hungarian as the language of official business and higher education. Between 1849 and 1860 the Habsburg government tried to impose German as the language of instruction but the decree issued by the reigning monarch in October 1860 reinstated the exclusive role of Hungarian. Understandably, some students from ethnic minorities whose Hungarian was not yet adequate for university academia sought to study in countries such as Austria, Germany, Serbia, or Romania, where they could receive instruction in their mother tongues. This preference partially explains why these ethnic groups were underrepresented in the Hungarian universities and other institutions of higher learning in 1900 (see Table 3.2).

There are no precise statistics on the mother tongue (nationality, ethnic affiliation) of the students from Hungary who were registered at the German universities and other institutions of higher education. However, one can infer their ethnic affiliation (mother tongue) from their surnames and provenance. Szögi (2006, p. 404) has asserted that $42.1 \%$ of the students from Hungary registered in Germany from 1789 until 1919 were

\footnotetext{
${ }^{48}$ Compulsory schooling was introduced in the Austrian part of the Habsburg monarchy under Empress Maria Theresia in 1774. It took many decades, however, until it could be enforced throughout the realm.
} 
Table 3.2 Ethnic composition of the population and students at the universities and other institutions of higher learning in Hungary (in percentages), 1900

\begin{tabular}{lccccccc}
\hline & \multicolumn{7}{c}{ Mother tongue } \\
\cline { 2 - 7 } Group & Hungarian & Romanian & Slovakian & German & Serbian & Other & Total \\
\hline Population & 51.4 & 16.6 & 11.9 & 11.9 & 2.6 & 5.6 & 100.0 \\
Students & 82.8 & 5.6 & 2.2 & 6.9 & 1.1 & 1.4 & 100.0
\end{tabular}

Source: Jancsó (2013, p. 37).

ethnic Hungarians; 33\%, Germans; 6.1\%, Slovaks; 2.1\%, Romanians; and $1.3 \%$, Serbs. He was unable to identify the nationality of $15.1 \%$ of the students.

\section{Where the Hungarian Students in Germany Studied, 1789-1919}

In the eighteenth century and the first two or three decades of the nineteenth, the universities at which the students from Hungary and Transylvania enrolled in Germany were still selected primarily according to the confessional character of those institutions. As of the mid-nineteenth century, however, the Hungarian students-except for the shrinking number of those in theology-based their choice ever less on the confessional alignment of the universities. Instead, they looked increasingly to the subject-matter specialization of the universities, the academic reputation of the professors, the cultural allure of the venue, and the scholarships and grants on offer.

The students from the upper strata of society generally wished to attend universities with a law program of high-quality. The places chosen by less-well-off students from Hungary were determined mostly by the grants and free meals that were available and by the independent organization of Hungarian students (on independent organization, see Stickler, 2006). Grants for needy students from Hungary and Transylvania were to be had from the Universities of Greifswald, ${ }^{49}$ Tübingen, and, later, Berlin (see Alvermann, 2006, pp. 346-347; Fata, 2006, pp. 244-246). The Evangelische Stift in Tübingen offered a certain number of students from Hungary and Transylvania free board, student dormitories, and tuition. Between 1661 and 1830, 85 students from Hungary received an education and free meals there (Fata, 2006, p. 244). In 1829 it was decided that theology students from

\footnotetext{
${ }^{49}$ To help the Protestants in Hungary, a scholarship fund reserved for Hungarian students was set up by Swedish King Karl XII at the University of Greifswald in 1705, a gesture that resulted in a constant stream of Hungarian students to that place. In the nineteenth century more Hungarians than Scandinavians were studying in Greifswald (Alvermann, 2006, pp. 346-347). In the European power politics of the Swedish crown, Upper Hungary was strategically important in the seventeenth and eighteenth centuries. It was manifested, for instance, in the alliance with the Transylvanian princes György Rákóczi I and II (pp. 347-348).
} 
Hungary should receive four scholarships of 150 Gulden each per year, a regulation that held until 1918 (Fata, 2006, p. 246). Hungarian students in Berlin enjoyed the special support of scholarships from the Hungarian state. ${ }^{50}$ Heidelberg University had no comparable sponsorship to offer, a lack that partly accounted for the disproportionately high number of students from Hungary's upper class and the much lower number of students from financially weaker families.

During the nineteenth century the concentration of Hungarian students gradually grew in the aspiring and culturally engaging metropolises of Berlin and Munich. The recruitment policy of Ministerial Secretary Friedrich T. Althoff (1839-1908) had won Berlin the reputation of being the best and most modern German university. Many celebrated professors regarded an appointment there as the very pinnacle of their career goals, above all after 1870. For Hungarian intellectuals, Berlin became a kind of postgraduate school. The sons of the Hungarian Jewish middle class in particular headed enthusiastically for Berlin (Ganter, 2006, p. 462). In Munich, the Technical University and the University of the Arts were exceedingly popular among the Hungarians (Fig. 3.12).

Some $65.5 \%$ of the 14,548 Hungarian students registered at universities in Germany from 1789 to 1919 were enrolled at five sites: Berlin (24.8\%), Munich (13.1\%), Leipzig (10.5\%), Jena (10\%), and Halle (7.1\%). Heidelberg ranked eighth (Szögi, 2001, p. 35). Between 1867 and 1890 Heidelberg University rose to sixth place thanks to its rising scientific reputation. In the nineteenth century Heidelberg University's disadvantage was that it offered no programs in engineering and technology, no business school (the nearest one was in Mannheim), and no art academy. It was one of the reasons that Heidelberg in the nineteenth century could no longer take the lead as it had in the second half of the sixteenth and early seventeenth centuries.

Analysis of the registries at Heidelberg University shows that $48.5 \%$ of all students from Hungary and Transylvania who had enrolled there between 1789 and 1919 had studied at at least one other German or Austrian university before they moved to Heidelberg; $8.0 \%$ had studied in Budapest and 0.4\% in Kolozsvár; and 3.4\% had enrolled at a university in Switzerland, Prague, or Paris. One can safely assume that the other $39.7 \%$ went to Heidelberg University first. The favorite universities sought out before study in Heidelberg were those in Berlin (16.4\%), Vienna (13.4\%), Budapest (8.0\%), Leipzig (5.2\%), Jena (3.6\%), and Munich (1.6\%). Unfortunately, the Heidelberg registries do not indicate how many of that university's enrolled Hungarian students went on to attend another university after their time in Heidelberg.

\footnotetext{
${ }^{50}$ After World War I Berlin gained an additional advantage: the Collegium Hungaricum, founded in 1924 for talented young Hungarian scholars (Siebe, 2006, p. 434). Germany's other university sites had no such facility.
} 

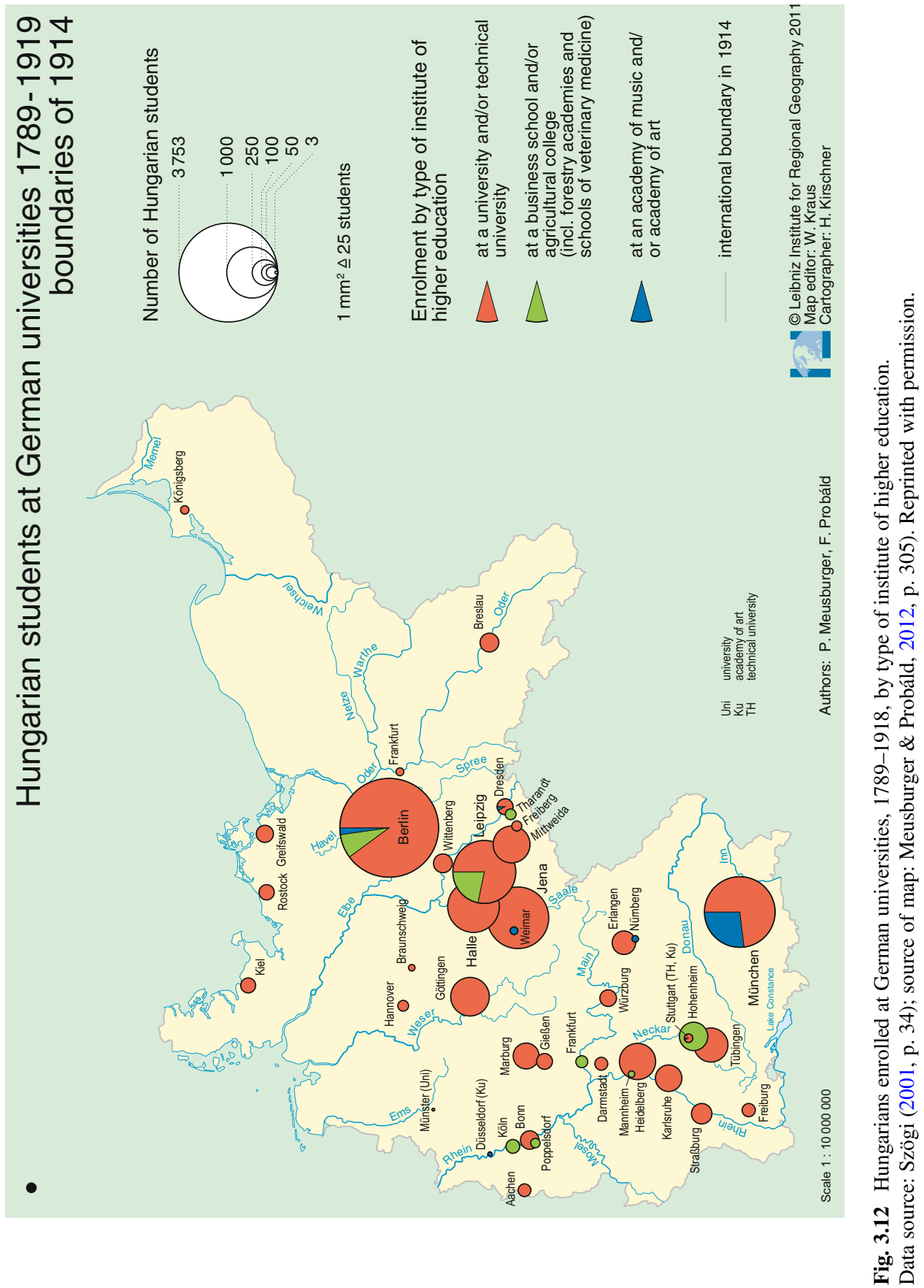


\section{Choice of Majors among Students from Hungary and Transylvania}

In the sixteenth, seventeenth, and eighteenth centuries students from Hungary and Transylvania went to Germany chiefly to study theology. This motive fundamentally altered during the nineteenth century. From 1789 to 1819 , theology was the major chosen by $92 \%$ of the Hungarian students in Germany, but that figure shrank to $54 \%$ by the years from 1849 to 1867 , to $27 \%$ between 1867 and 1890 , and to $14 \%$ in the final decades before World War I (Szögi, 2006, p. 395).

The processes of economic and social modernization and Hungary's recovery of broad political independence after the Compromise of 1867 affected more than the number of Hungarians studying in Heidelberg. It had an even larger impact on their choice of what to study (see Table 3.3). The percentage of Hungarian students enrolled in law and Staatswissenschaften ${ }^{51}$ at Heidelberg University from 1871 to 1910 was nearly quadruple that of the years from 1789 to 1850 . The corresponding percentages in the philosophical and natural science faculties doubled. By 1890 the percentage of Hungarian medical students at Heidelberg University had also doubled but then plummeted, presumably because medical training at the University of Vienna had meanwhile achieved world renown ${ }^{52}$ and was closer to home. Moreover, medical studies in Budapest, too, had reached a high level by the late nineteenth century.

Heidelberg University accounted for $31 \%$ of all Hungarian students studying law in the years from 1789 to 1919 , a number more than double that of all Hungarian students in Germany (13.4\%). The high share of lawyers may be surprising because Germany's legal code vastly differed from Hungary's. However, a disproportionately high number of Hungarian students studying law or Staatswissenschaften in Heidelberg were from the upper social strata in Hungary. According to Szögi (2006, p. 396), it was frequently the case that sons of that country's political elite studied at famous law faculties abroad for one or two semesters although they had already earned an academic degree in Hungary. This practice is also one of the reasons that approximately $16 \%$ of the Hungarian students were older than 24 years of age, with $2.5 \%$ even being more than 30 years old upon enrolling at Heidelberg University. Hungarians also accounted for $15.2 \%$ of the university's medical students, a figure nearly two and a half times higher than that among all Hungarian students in Germany (6.8\%) (Szögi, 2001, 2006, pp. 394-397).

\footnotetext{
${ }^{51}$ Staatswissenschaften used to be the term for those fields of scholarly endeavor focused on the state. In general, they were state, administrative, and international law; the law of public finance; political sociology; policy science; political economy, public finance; administrative theory; statistics; and sometimes ethnology and ethnopsychology. Today, Staatswissenschaften is taken to mean interdisciplinary courses of study that combine jurisprudence, economics, and social sciences (sociology and policy science). Such programs are comparable to those on governance and public policy.

${ }^{52}$ By 1750 the medical faculty of the University of Vienna had become one of Europe's leaders in the training of physicians.
} 


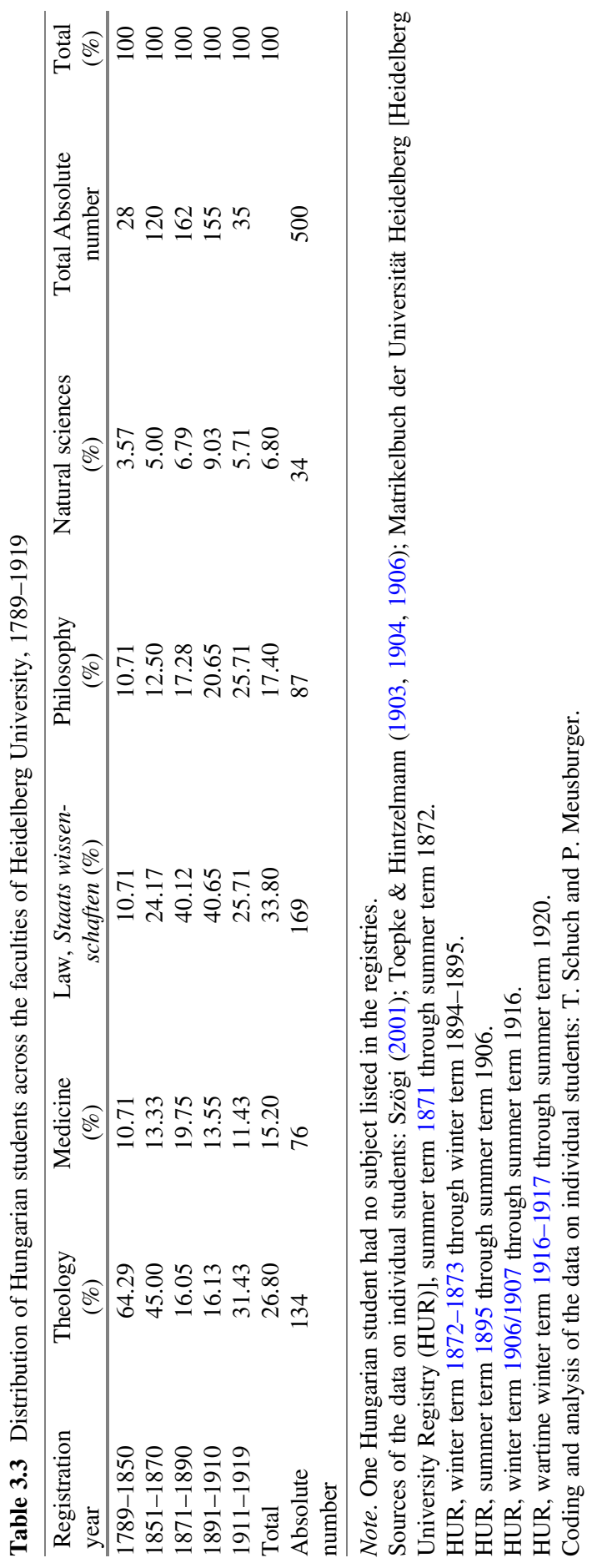




\section{Social Origin and Choice of Subject of the Hungarian Students in Heidelberg}

In this chapter the social strata of the Hungarian students attending Heidelberg University is elicited through the occupation of the father (legal guardian), which is recorded for $89.4 \%$ of the students listed in the university's registries. From 1789 through 1919, a disproportionately high percentage of the Hungarians studying in Heidelberg were from the upper social strata (see the first two rows in Table 3.4). More than a quarter (26.4\%) of the students had a father who was a major landowner, politician, factory owner, entrepreneur, banker, or some other leading figure in the economy. The historically eminent aristocratic Hungarian names listed include Bánffy, Eötvös, Jeszenszky, Degenfeld-Schomburg, Szily, Teleki, Tisza, und Wesselényi. Clerical occupations (pastors or rabbis) accounted for $12.2 \%$ of the fathers, whereas $5.4 \%$ of the fathers were teachers or professors, and only $9.0 \%$ of the fathers were artisans, junior officials, or farmers.

In the first half of the nineteenth century, when studying theology was still relatively important among the Hungarian students in Heidelberg, 32\% of the students came from families in which the father was a cleric or teacher. The steepest decline in Heidelberg University enrollments among students from Hungary between 1789 and 1919 - from $25 \%$ to $5.6 \%$-was among the sons of pastors. After 1850 the share of upper-class students rose rapidly, with three discernible phases in its composition. The first influx consisted of students whose fathers were major landowners, politicians, and parliamentarians. From 1851 to 1870 , this group accounted for $20.8 \%$ of the Hungarian students at Heidelberg University. After 1871 the share of students consisting of the sons of Hungarian society's leading factory owners, entrepreneurs, and bankers expanded markedly. The wave from 1891 to 1910 was dominated by sons from merchant families, Jewish ones above all.

Unsurprisingly, the choice of a major or discipline within the university was largely a function of the social origin of the Hungarian students (Table 3.5). Just over $67 \%$ of the sons of major landowners and politicians studied law or Staatswissenschaften in Heidelberg. Among the sons of senior public officials, military officers, and self-employed academics, the share was $40.3 \%$; among sons of clerics, only $13 \%$; and those of teachers, $11 \%$. The children of physicians and apothecaries also inherited high status, focusing as they did on studying medicine. By contrast, the sons from the middle and lower social strata went mostly for theology and philosophy (teaching occupations), preferring to prepare themselves for fields that promised a regular income beginning immediately after completion of a relatively short and inexpensive course of study. Theology was the leading subject of study among the sons of clerics $(62.3 \%)$; of artisans, junior officials, and farmers (42.2\%); of teachers and professors (40.7\%); and, to a far lesser extent, of traders and merchants $(10.6 \%)$. The association between upward social mobility and academic occupations, especially those of the clergy and teachers, has been verified many times in other countries, too. 


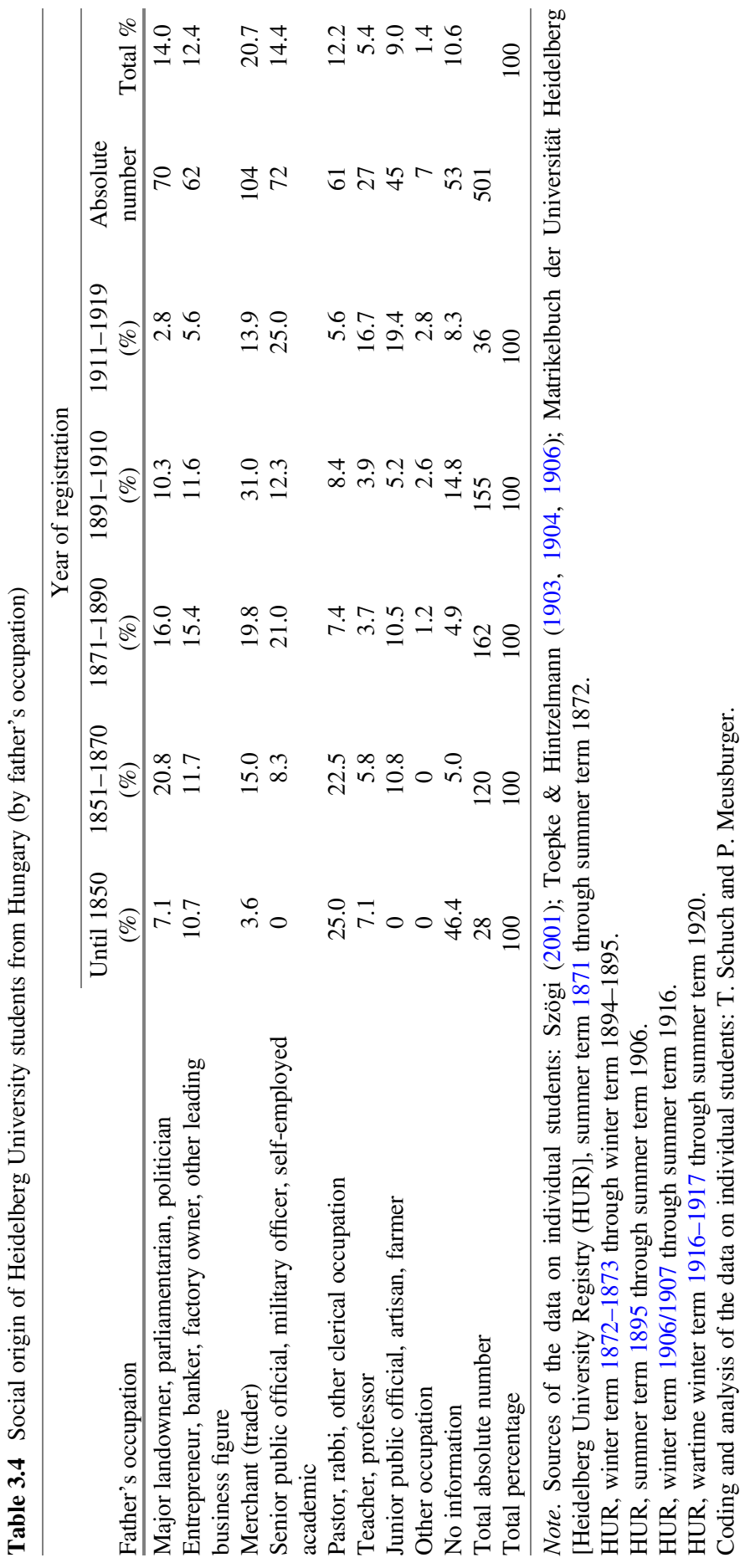




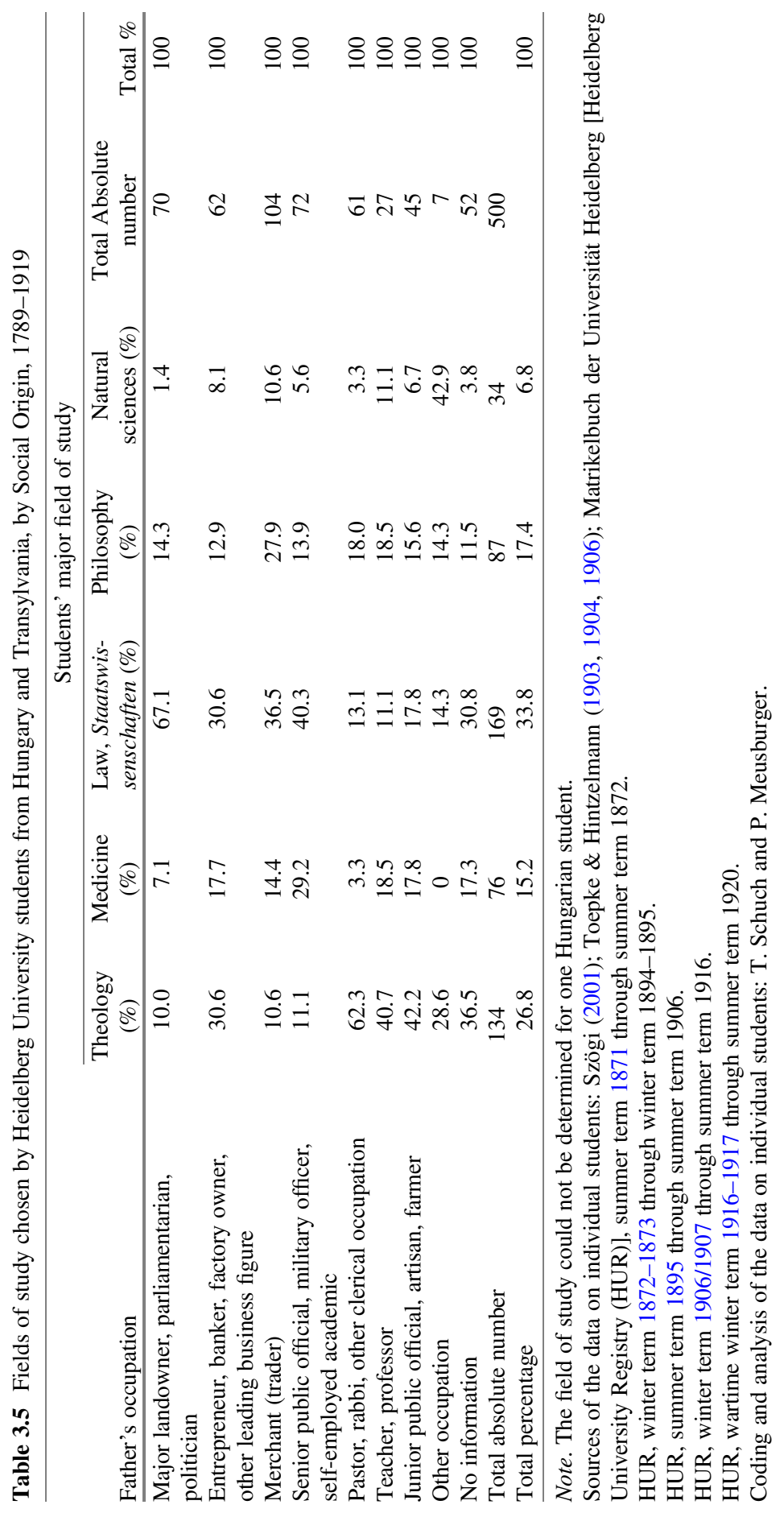


The fall in the share of theology students had several consequences. First, the percentage of students from Hungary's middle and lower social strata and from the country's towns and rural regions distinctly shrank, and the share of students from Budapest and other large cities swelled. As the demand for theology studies waned, as the spectrum of subjects offered in Heidelberg opened up, and as Hungary's society and economy modernized, the confessional scope also widened among the Hungarians who enrolled at Heidelberg University during the nineteenth century.

\section{Religious Confession of the Hungarian Students Enrolled at Heidelberg University}

Analysis of the religious confession of the Hungarians studying in Heidelberg sheds additional light on the fluctuating role and significance of Heidelberg University in the training of Hungarian elites and on the processes of structural transformation, liberalization, and processes of modernization in Hungarian society, particularly between 1867 and 1919. When assessing the data presented in Table 3.6, one should bear in mind that $49.3 \%$ of Hungary's population ${ }^{53}$ in 1910 was Roman Catholic; 14.3\%, Reformed (Calvinist); 12.8\%, Greek Orthodox; 11\%, Greek Catholic; $7.1 \%$, Evangelical (Lutheran); 5.0\%, Jewish ${ }^{54}$; and 0.4\%, Unitarian (Központi Statisztikai Hivatal, 1920). In other words, Lutherans, Israelites, and Calvinists were the most overrepresented groups among the Hungarian students in Heidelberg, whereas Roman Catholic, Greek Catholic, and Greek Orthodox students were clearly underrepresented. Table 3.6 also reflects the change in the motives Hungarian students had for studying in Heidelberg (see immediately preceding section). During the nineteenth century, Heidelberg lost its function as a key "forge" of Hungary's Calvinist elite. In the latter half of the 1800s, Heidelberg's attraction was primarily the scientific reputation of the faculties. The data also document the social development within Hungarian society - notably the social ascendance of the Jews. Having been liberated from discrimination after the Compromise of 1867, they played a salient role in the rise of Hungary's new economic and intellectual elite, contributing impressively to the country's economic boom, the development of Hungarian culture and sciences, and German-Hungarian relations in the sciences and higher education (for details see Karády, 1997, 2004, 2012, 2013; Karády \& Nagy, 2012).

From 1891 to 1910 , the percentage of Jews among the Hungarian students at Heidelberg University was nearly four times higher than that from 1789 to 1850 . In the five years from 1886 through 1890, the share of Heidelberg's Hungarian students who were Israelite came to $31.3 \%$ and climbed as high as $58.3 \%$ from 1891 through 1895 (see also Fig. 3.11). Between 1867 and the late 1920s, Hungarian Jews were remarkably active in German culture and science (Frank, 1999; Gantner, 2006).

\footnotetext{
${ }^{53}$ The immediately following statistics do not include Croatia and Slavonia.

${ }^{54}$ In the university's registries most Jewish students denominated themselves as Israelites-a frequently used term in the nineteenth century. Accordingly, we use this self-designation synonymously with the term Jews.
} 


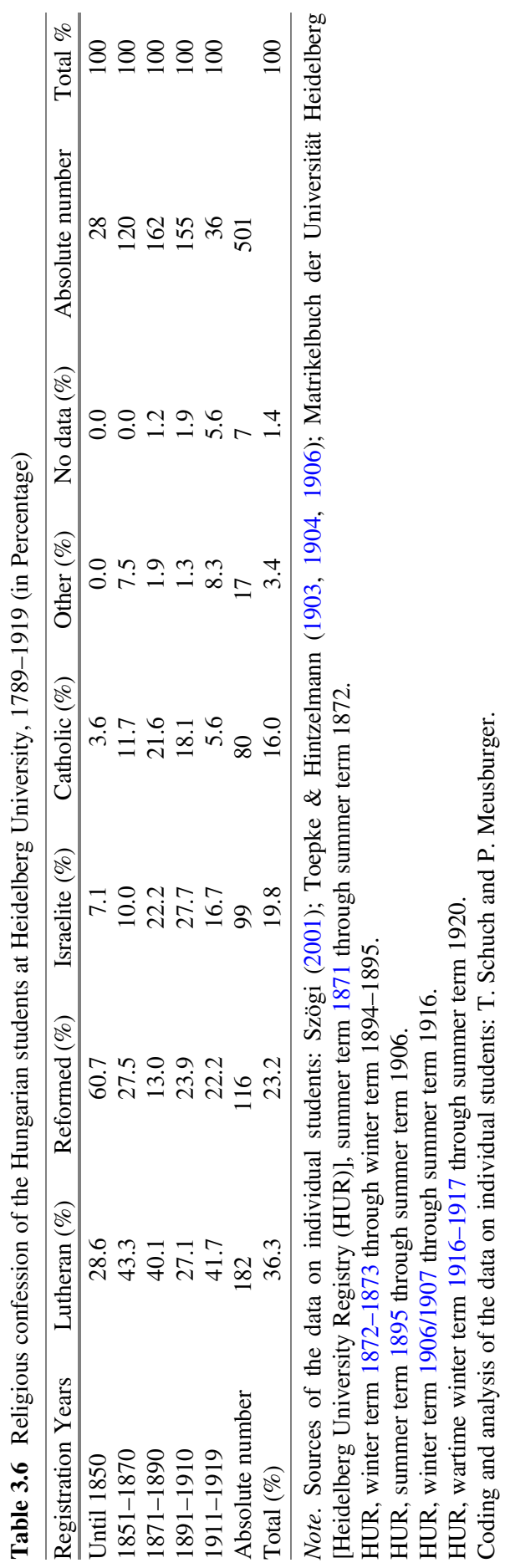




\section{An Explanation of the Soaring Number and Percentage of Jewish Students}

Hungary's Israelite population expanded twelvefold between 1780 and 1910, in the latter year accounting for 5\% of the country's population and up to $23 \%$ in the capital city, Budapest. This growth in the Jewish segment of the population was due essentially to the enormous immigration of Jews from Galicia, Moravia, and other regions of the Habsburg empire. The waves of Jews arriving in Hungary, notably Budapest, were triggered principally by the fact that Jews generally encountered more tolerance and better opportunities to move up the social ladder in Hungary than in many other European countries. The March 1783 Josephine decree "Systematica Gentis Judaicae Regulatio" (Systematic Regulation of the Jewish Nation), issued in the spirit of the Enlightenment, opened the way for the Israelites to study at the universities in the Habsburg empire. In the first half of the nineteenth century, the Israelites concentrated mostly on medicine, economics, and Jewish theology at the universities of Prague and Vienna; and medicine at the University of Pest as well.

Article XXIX in the law of 1840 granted Jews the right to settle in all Hungarian cities and the license to engage in trade and commerce. The Emancipation Act XVII of 1867 gave full equality to the Jews in Hungary, launching an almost seamless 50 -year process of assimilation whose success was unprecedented and greatly promoted by the attitude of Hungarian society. The rapid social rise of Jews was propelled by a number of other circumstances, too. First, the urban middle class was traditionally very narrow in Hungary, so a large potential for social upward mobility existed. Second, the social and economic processes of modernization in the second half of the nineteenth century markedly escalated the demand for self-employed persons with an academic background (attorneys, physicians), scientists, and providers of services in certain fields (banking, media, cultural institutions). Third, because the Jews had an above-average level of education, they were able to meet the intense demand for highly qualified people in the economy. In that field they met little competition, for the members of the lower nobility had a manifest inclination to enter public service instead. Lastly, there were few apparent signs of discrimination against Jews in the final third of the nineteenth century. In that liberal and tolerant age the appearance of an anti-Semitic party in 1883 remained a brief and marginal political episode. $^{55}$

Combined with various measures of the Hungarian state to strengthen Hungarian national identity, these positive conditions for Jews led to shifts in the national (cultural) identity of the Jews. In the census of 1910, more than three quarters of the Jews stated that their mother tongue was Hungarian, whereas the share of the Jews in Hungary who claimed German as their mother tongue contracted from $33.3 \%$ to 21.7\% between 1880 and 1910 (Gantner, 2006, p. 461). "Acquisition of the Hungarian language and culture in Jewish middle-class families by no means meant a

\footnotetext{
${ }^{55}$ The prime minister, Kálmán Tisza, resolutely rejected anti-Semitism (Stokes, 1989, p. 225).
} 
rejection of the relations to German culture. Rather, the simultaneous existence of the German and Hungarian language and culture was taken for granted" (p. 461).

As "people of the written Word," Jewry has always treasured education and intellectual occupations. As in other countries, Jews in Hungary were heavily overrepresented in universities and other institutions of higher learning. The share of Jews among students in Gymnasien and Realschulen-school types preparing 10to 18-year-olds for higher education-rose from $9.6 \%$ (1866-1867) to $22.5 \%$ (1913-1914). They accounted for approximately $10 \%$ of the students at Hungary's universities and other institutions of higher learning in the 1860s but more than $25 \%$ by 1885, exceeding 30\% during World War I (Kovács, 1922; Sebók, 2013). According to Gantner (2006), 17.7\% of the students at the University of Budapest in 1867 were Jews and $29.6 \%$ by 1895 . The 1891 census recorded that $32 \%$ of the student body at the University of Budapest was Jewish (p. 463). Karády (1997) stated that, on average, Jewish school students also had better grades and lower dropout rates than the average for their Hungarian peers. Furthermore, Jews chose their major subject of study and their future occupation very purposefully, flexibly adapting to demand molded by social, technological, and scientific progress (Szögi, 2004; Volkov, 1987). Jews were especially well represented among entrepreneurs (factory owners) in Hungary, in banking, and among self-employed people with an academic background. In 1910 Jews accounted for $48 \%$ of the physicians, $45 \%$ of the lawyers, and $42 \%$ of the journalists, although Jews made up only $5 \%$ of the total Hungarian population (Kovács, 1922; Sebók, 2013). Their contribution to Hungarian science and art, too, was invaluable. What they did to modernize Hungary was recognized by the country's government: “[B]etween 1900 and World War I over 200 Hungarian Jewish families were ennobled” (Stokes, 1989, p. 225).

\section{Social Origin of the Jewish Students at Heidelberg University}

Hungary's well-off Jewish factory owners, entrepreneurs, merchants, bankers, and self-employed academics, who had excellent language skills and international connections alike, naturally sought the best education for their sons and encouraged them to spend time abroad. Fully $53.5 \%$ of the fathers of the Israelite Hungarian students who had enrolled at Heidelberg University from 1789 to 1919 were businessmen (traders), $21.3 \%$ were part of the economy's leading stratum (the first two categories in Table 3.7), with $8.1 \%$ being self-employed academics or rabbis. The share of students from the middle and lower social strata was much smaller among the Jews studying in Heidelberg than among the other confessions. Compared also to the Jewish students at other German universities, the Jews studying in Heidelberg came in disproportionately large numbers from the upper classes (see Gantner, 2006, pp. 463-464).

Some $18.7 \%$ of the Lutheran students had a pastor for a father; $18.1 \%$, a father who was a senior public servant, military officer, or self-employed academic. By contrast, the social profile of the Calvinist students, peaked at nearly opposite ends of 


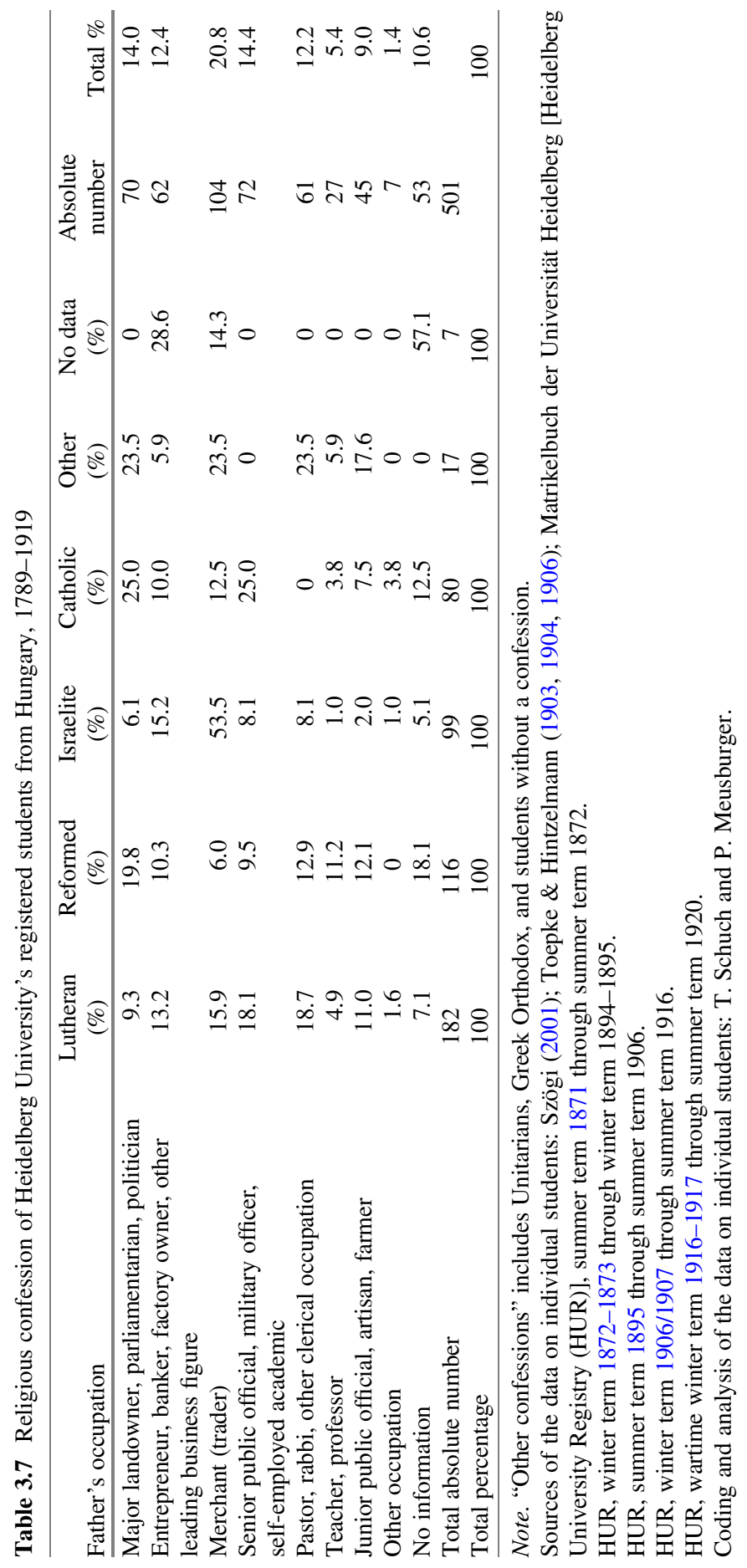


the range, with $30.1 \%$ coming from the upper strata of society and $36.2 \%$ from fathers who were clerics, teachers, artisans, junior public officials, or farmers.

\section{Heidelberg: One of the First German Universities to Accept Jewish Students}

Did the preponderance of Jews among the Hungarian students at Heidelberg University perhaps owe to the latter's reputation as a liberal, tolerant institution since the early nineteenth century (see Engehausen, 2012; Honeck \& Meusburger, 2012; Meusburger, 2012; Wolgast, 1987) and the fact that its professors and students championed democratic reforms early? The university in Heidelberg was one of the first in Germany to accept Jewish students (1724), graduate Jewish students (1728), and appoint Jews as professors (1766) (Meusburger \& Schuch, 2010, pp. 64, 71-74; Richarz, 1974, pp. 29-33). ${ }^{56}$

The first Jewish professor at Heidelberg University was Daniel Wilhelm Nebel. He completed his doctorate in Heidelberg in 1758, was appointed as an associate professor of medicine at Heidelberg University in 1766, and became a full professor in 1771. By 1860 two more Jews had become professors at Heidelberg, as had four Jews who had converted to Christianity. However, the real rise of Jewish professors at Heidelberg University did not begin until after the revolution of 1848 . Between 1851 and $1870,8.9 \%$ of Heidelberg's newly appointed professors were Jewish (for details see Meusburger \& Schuch, 2010, pp. 71-74).

When interpreting these numbers, one should bear in mind Germany's 1910 census, in which Jews accounted for only $1.2 \%$ of the total population of Baden and $0.95 \%$ of the population of the Second German Reich (Titze, 1987). Thus, the proportion of Jews among Heidelberg's professors was nearly ten times that of Jews in the population as a whole (for explanations see Volkov, 1987). By comparison, the percentage of Heidelberg University's professorships that were held by Catholics in 1910 corresponded to only a quarter of the Catholic share of the German population as a whole.

The available data are inconclusive about whether the proportion of Jewish professors in the second half of the nineteenth century had a documentable effect on the share of Jews among the students from Hungary. Even German universities at which Jews accounted for only a small percentage of the professors attracted many Jewish students from Hungary after 1867. At the 15 German institutions of higher learning that recorded the religious confession of their students, ${ }^{57} 23 \%$ of the students were Israelites, according to Szögi (2004). He estimated that Israelite students accounted for $21 \%$ of the Hungarian student body at German universities, $28 \%$ at the technical universities, $30 \%$ at the agricultural academies, and $50 \%$ at the

\footnotetext{
${ }^{56}$ A plan to appoint the philosopher Spinoza as a professor at Heidelberg University failed in 1673.

${ }^{57}$ These institutions accounted for approximately $37 \%$ of the Hungarians enrolled in Germany at that time.
} 
universities for trade and commerce. The universities for trade and commerce in Leipzig, Berlin, Mannheim, and Cologne were particularly popular (Gantner, 2006, p. 464). At the Technical University of Berlin, where Hungarians usually studied chemistry and electrical engineering, Jews accounted for about $40 \%$ of the Hungarian students between 1867 and 1919. This figure roughly matched the share of Jews at the Technical University of Budapest.

\section{Regional Origin of the Hungarians Studying in Heidelberg, 1789-1919}

The places of birth or residence ${ }^{58}$ of the 501 Hungarian students enrolled at Heidelberg University between 1789 and 1919 were distributed throughout Hungary but clearly preponderated in today's Budapest (15.2\%) and in the Transylvanian cities of Nagyszeben (today Sibiu, 6.0\%), Brassó (Braşov, 5.4\%), Meggyes (Mediaş, 2.8\%), Segesvár (Sighişoara, 2.2\%), Beszterce (Bistrița, 2.0\%), Szászrégen (Reghin, $2.0 \%$ ), and Kolozsvár (Cluj-Napoca, 1.8\%). Kecskemét und Pozsony (today's Bratislava) each accounted for $1.6 \%$ of the Hungarian students; Miskolc and Debrecen, each $1.0 \%$ (see Fig. 3.13).

An especially high number of students were thus sent to Heidelberg by cities with a strong Protestant tradition and important administrative institutions of the Protestant church, cities with a high percentage of German-speaking or Jewish inhabitants, and cities with superior Gymnasien. Because of the central-place hierarchy of Hungary's settlement system and the resulting dissimilarities in the social stratification of the population, the large cities and the rural periphery differed substantially in terms of the students' social origins and chosen subjects of study. About two thirds of the sons of teachers and clerics came from towns and rural areas. Only $1.3 \%$ of the students from Budapest enrolled in theology; 58.2\% in law and Staatswissenschaften. Towns and rural areas offered quite the opposite picture, with $31.9 \%$ of all students from those places enrolling in theology, and only $27.6 \%$ choosing law and Staatswissenschaften. The share of students from Transylvania who focused on theology $(39.1 \%)$ was more than twice that of the students from the rest of Hungary $(19.2 \%)$. The share of medical students from Transylvania $(20.3 \%)$ was also much higher than in the rest of Hungary $(12.0 \%)$.

The nineteenth-century shifts in social origin and choice of subject altered the spatial pattern of the students' places of origin as well. Between 1789 and 1919 the regional origin of the Hungarians and Transylvanians studying in Heidelberg moved distinctly westwards. The share of all Hungarian citizens from Transylvania enrolled at Heidelberg University declined from $54.2 \%$ (1789-1850) to $39.1 \%$ (1851-1900), ultimately sinking to $33.6 \%$ (1901-1919). Increasing vertical mobility led to a rise in

\footnotetext{
${ }^{58}$ Szögi (2006, p. 400) points out that the registries noted the place of residence rather than the place of birth for some of the students.
} 
- Students from Hungary at Heidelberg University 1789-1919 by place of origin

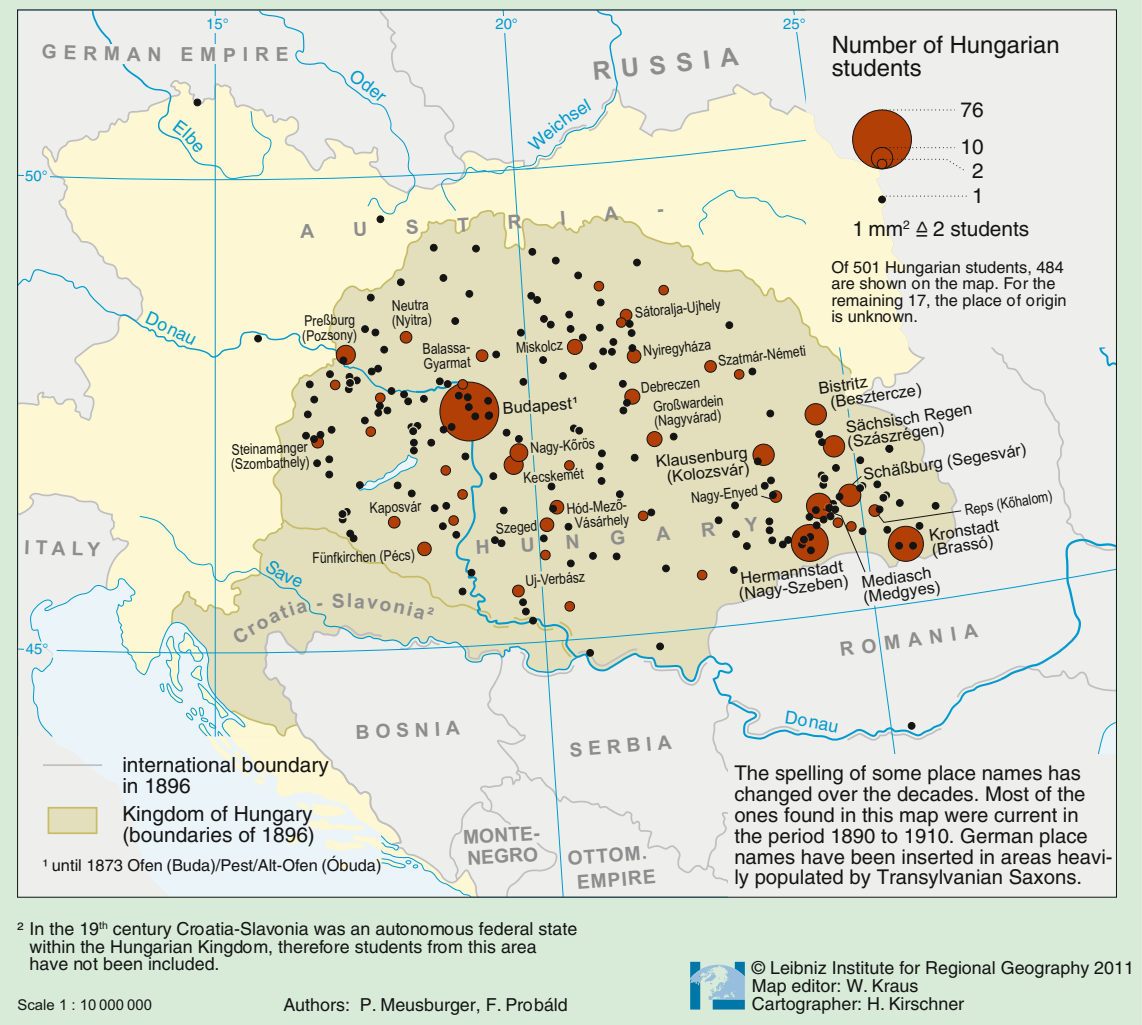

Fig. 3.13 Hungarian students at Heidelberg University, 1789-1919, by place of origin.

Data source: Szögi (2001, p. 34). Source of map: Meusburger \& Probáld, 2012, p. 305. Reprinted with permission.

the share of the enrolled students from small towns and rural areas-from $29.1 \%$ (1789-1850), 47.6\% (1851-1900), and 54.8\% (1901-1919). After 1890 many fewer children of teachers and clerics studied in Heidelberg, but more children of merchants and traders did.

Overall, the share of the Hungarian students from the urban middle class was somewhat higher in Heidelberg than the average share of all Hungarians and Transylvanians studying in Germany. A total of $40.6 \%$ of the Hungarians and Transylvanians who registered in Heidelberg came from 10 cities. According to Szögi (2001, pp. 52-53), only 33.1\% of the entire number of Hungarian students in Germany were from there. Table 3.8 summarizes the key shifts in four main characteristics of the Hungarian students at Heidelberg University from the seventeenth to the nineteenth century. 
Table 3.8 Representation of the social groups among Heidelberg University's students from Hungary as compared to their share of Hungary's total population

\begin{tabular}{lccccc}
\hline & \multicolumn{2}{c}{17 th century } & & \multicolumn{2}{c}{ 19th century } \\
\cline { 2 - 3 } \cline { 5 - 6 } Characteristic & Very high & Very low & & Very high & Very low \\
\hline Mother tongue & Hungarian & Other & & German & Romanian, Slavic \\
Religion & Calvinist & Other & & Israelite, Protestant & Greek Orthodox \\
Social origin & Lower middle class & Serfs & & Upper classes, land owners & Farmers, workers \\
Subject & Theology & Other & & Law, theology & Other \\
\hline
\end{tabular}

Source: Design by authors.

\section{Eminent Figures from Hungary Who Studied in Heidelberg in the Nineteenth and Early Twentieth Centuries}

There are at least three reasons not only to study academic relations, student migration, and influences of universities at the structural level but also to delve into the biographies and networks of outstanding individual protagonists. First, a biographical approach can contribute knowledge about the spatial diffusion of ideas and scientific methods that a structural approach cannot yield. Analysis of biographies, letters, minutes of meetings, and personal interviews makes it possible to recognize motives that have affected decisions and to identify events (situations) and people who have promoted or impeded the learning and academic or political careers of the students in question. Academics can generally identify whom they received encouragement, suggestions, and support from while engaged in their studies or academic career and where they met resistance to their ideas or lack of interest in them (see chapter on knowledge milieus by Meusburger in this volume). The biographical method can (within certain limits ${ }^{59}$ ) trace the charisma and impact of individual professors or faculties on their students and, hence, on the spatial diffusion of ideas and methods (e.g., Eckart, Hübner, \& Nawa, 2012; Hübner, 2010).

Second, a biographical approach can reconstruct networks of mutual support and emotional attachment to places, personal animosities, and gulfs between scientific schools of thought. Numerous examples illustrate how friendships, loyalties, and antipathies that form between students during their time together at a university later become decisive factors in communication processes and career decisions.

Third, only the biographical method makes it possible to grasp how the structural elements of a knowledge milieu have actually affected students and scientists. One must avoid a deterministic understanding of the weight that universities or professors have in the intellectual development and occupational careers of students. The recipient of information is always the one who decides whether or not to appropriate a locally accessible resource; whether and how to take suggestions, critique, and criticism; and how to exploit opportunities and assess risks. Much of a knowledge milieu's potential goes unrecognized or unused by many of the actors.

\footnotetext{
${ }^{59}$ An institute's knowledge milieu is not an independent variable exerting a particular effect. It represents a local potential that can be used or ignored (for details see the chapter by Meusburger in this volume).
} 
German universities contributed a great deal to educating Hungarian elites in the nineteenth and twentieth centuries. According to Szögi (2006, pp. 406-407), 114 Hungarian government officials and professors of the University of Budapest studied in Germany between 1867 and 1945, most of them in Berlin, Leipzig, Göttingen, and Heidelberg. These 114 people included five Hungarian prime ministers, seventeen ministers, and two commissars of the Hungarian Soviet Republic. ${ }^{60}$ Many alumni of German universities sat as representatives in the Hungarian parliament as well, ${ }^{61}$ and their share of the seats mounted steadily until World War I. From 1910 to $1915,13.8 \%$ of the members of the upper house and $10.4 \%$ of the representatives in the lower house had completed a university degree in Germany, most of them in Berlin, with the University of Leipzig and Heidelberg University following in that order (Tar, 2007, pp. 112-113). The next two sections present just a few of the Hungarian politicians and scientists who studied in Heidelberg and went on to fame.

\section{Scholars in the Liberal Arts, Social Sciences, and Economics ${ }^{62}$}

Hugo Meltzl von Lomnitz (1846-1908), the son of a brewery owner from Szászrégen, enrolled at Heidelberg University in November 1866, where he became a student of Karl Bartsch (1832-1888), the renowned professor of the German language and culture. Meltzl received his doctorate cum laude from Heidelberg in 1872. The University of Kolozsvár was founded in the same year, and Meltzl had the good fortune to become full professor of German there at the age of 26. He was close friends with Loránd Eötvös (see later in this chapter), with whom he had studied in Heidelberg, and translated poems by Loránd's father, József Eötvös, into German (Fassel, 2006, pp. 438, 453). Meltzl specialized in comparative literature, researched the origins of European and non-European literature as a foundation for studying comparative literary development. In 1877 he began editing the world's first comparative journal, the Acta comparationis litterarum universarum (Journal of Comparative Literature), which appeared from 1879 to 1888 and contained essays in 20 languages (p. 439).

Count István Tisza (1861-1918), a son of Kálmán Tisza (the prime minister of Hungary from 1875 to 1890 ), enrolled in law at Heidelberg University in 1879 . He received a doctorate in political science when he was just 20 years old. In 1910 he became a member of the Academy of Sciences (economic sciences). As a leader of the Liberal Party, Count István Tisza was prime minister of Hungary from 1903 to 1905 and from 1913 to 1917 (Tökéczki, 2010). He staunchly endorsed the Austro-

\footnotetext{
${ }^{60}$ The Hungarian Soviet Republic was proclaimed on March 21, 1919, and ended 133 days later, on August 1, 1919.

${ }^{61}$ The Hungarian parliament (Magyar Országgyúlés) consisted of two chambers, the House of Magnates (Fórendiház), in which the members of the high nobility and the high clergy sat, and the House of Representatives (Képviselóház) with members elected by the votes of the electorate.

${ }^{62}$ Unless otherwise cited, the information in this section is based on articles in Markó (2001-2007).
} 
Hungarian Compromise and strove to ensure the survival of the dual monarchy. $\mathrm{He}$ opposed Austria-Hungary's declaration of war on Serbia in July 1914 but had to yield to the overwhelming pressure in favor of it. At the end of World War I, he was made a public scapegoat and murdered in his house in October 1918.

Sándor Imre (1877-1945) studied education in Heidelberg and Leipzig (1899-1900). After 1919 he served briefly as an undersecretary in the Ministry of Culture. He was a full professor of education at the University of Szeged (1925-1934) and at the Technical University of Budapest (1934-1944). He tried to apply German social pedagogy in Hungary (Szögi, 2006, p. 407) and introduced the study of psychology at Hungarian universities. The first Institute of Psychology was founded upon his initiative at the University of Szeged in 1929.

Endre Bajcsy-Zsilinszky (1886-1944) studied law in Kolozsvár, Leipzig, and Heidelberg, where he broke off his studies in 1908 without earning a doctorate. Bajcsy-Zsilinszky cofounded the National Radical Party (Nemzeti Radikális Párt) in 1930, which he represented in the Hungarian parliament until 1935. After 1939 he represented the Hungarian Smallholders' Party until his death. During World War II, Bajcsy-Zsilinszky was among the foremost opponents of Hungary's participation in the war and the alliance with the German Reich. In parliament he successfully pressed for prosecution of General Feketehalmy-Czeydner, who had ordered mass executions in Újvidek (Novi Sad, Yugoslavia) in 1942. ${ }^{63}$ After the German occupation of Hungary in March 1944, the Gestapo captured Bajcsy-Zsilinszky but released him in October. He went underground after the coup by Ferenc Szálasi, a Hitler loyalist and leader of the Arrow Cross Party, a National Socialist organization in Hungary. Bajcsy-Zsilinszky was arrested as the leader of the resistance movement and executed in Sopronkóhida on December 24, 1944.

Several Hungarian members of the Budapest Vasárnapi Kör (Sunday Circle) studied and researched in Heidelberg from 1912 until the late 1920s (for details about the Sunday Circle, see Gräfe, 2004; Karadi, 1986; Karadi \& Vezer, 1985; Loewy, 1999; Wessely, 1986). This group included György Lukács, Karl Mannheim, Béla Fogarasi, and László Radványi, of whom the rest of this section highlights only Lukács and Mannheim, the two best known members. Not only did their experience in Heidelberg differ radically, they also went separate ways later.

The pivotal figure of the Sunday Circle in Heidelberg was György Lukács (1885-1971), ${ }^{64}$ a Marxist philosopher, literary scholar, and subsequent people's commissar of the Hungarian Soviet Republic. He lived intermittently in Heidelberg from 1912 until 1917 and wrote some of his seminal works there. Lukács came from a wealthy Jewish family. His father served as a court councilor and was an important actor in finance capital as managing director of the English-Austrian Bank and

\footnotetext{
${ }^{63}$ The Axis Powers had occupied Yugoslavia in 1941.

${ }^{64}$ The following biographical details on Lukács are drawn from Bendl (1998), Benseler (1987), Borbándi (1973), Karadi (1986), Kuzias (2007), Loewy (1999), and Vorlaufer (1993).
} 
director of the Hungarian General Credit Institute in Budapest. ${ }^{65}$ In 1902 György Lukács began studying law and economics in Budapest, earning a doctorate in Kolozsvár in 1906. In 1907 he met Georg Simmel (1858-1918), who greatly impressed him and whose aesthetic philosophical impressionism had an effect still evident in Lukács's late theory of aesthetics. Lukács studied philosophy at the University of Berlin in the 1908-1909 academic year and completed his doctorate at the University of Budapest in 1909. When Lukács arrived in Heidelberg in 1912, he thus already had a doctorate in Staatswissenschaften (1906) and one in philosophy (1909). He was also already known as a writer through his essays entitled Die Seele und die Formen (1911; English translation, 2010: Soul \& Form), for which Georg Simmel had been an inspiration.

He went to Heidelberg University to complete his Habilitation (postdoctoral work) under Wilhelm Windelband (1848-1915) and to prepare himself for a university professorship in philosophy. ${ }^{66}$ To Lukács, the university was less a training center than an intellectual forum, a place for exchanging ideas (Gantner, 2006, p. 467). He quickly joined the circle around Max Weber (1864-1920) and took part in the "sociological discussion evenings" led by Max's brother, Alfred Weber (1868-1958) (for details see Lepsius, 2012). In 1914 Lukács married his first wife in Heidelberg, the Russian painter and anarchist Jelena Grabenko, from whom he separated in 1918. In 1914 and 1915 he delved into Hegel, Marxism, anarcho-syndicalism, and Edmund Husserl. The personal relations he forged in Heidelberg with Emil Lask (1875-1915), Stefan George (1868-1933), Friedrich Gundolf (1880-1931), Ernst Bloch (1885-1977), Karl Jaspers (1883-1969), Alfred Weber (1868-1958), Max Weber (1864-1920), Eberhard Gothein (1853-1923), Gustav Radbruch (1878-1949), Emil Lederer (1882-1939), Hans von Eckhardt (1890-1957), and other famous people not only shaped and challenged him intellectually but occasionally benefited him in other ways as well. Karl Jaspers, for instance, who was also a practicing neurologist, issued a medical certificate that exempted Lukács from military service in 1914. In 1915 Lukács did have to serve briefly as a military censor of letter correspondence, a task from which was discharged in the summer of 1916 thanks to family connections (Bendl, 1998, pp. 21-22). Lukács returned to Heidelberg in 1916 and moved to Budapest in $1917 .{ }^{67}$

From Budapest in 1918, he applied to Heidelberg University for the opportunity to begin the multiyear postdoctoral process of qualifying for a university chair (Habilitation). Alfred Weber vigorously backed Lukács's plans and personally advanced them in his interaction with various faculty members (Demm, 1990, pp. 63-64;

\footnotetext{
${ }^{65}$ While in Heidelberg, Lukács received annual support of 10,000 marks from his father (Loewy, 1999, p. 174).

${ }^{66} \mathrm{He}$ therefore did not need to enroll at the university.

${ }^{67}$ Before leaving Heidelberg, Lukács packed his manuscripts, notes, diaries, and letters into a suitcase, which he deposited in a safe at the Deutsche Bank in the city, where it lay nearly 50 years until discovered after Lukács death (Bendl, 1990).
} 
2000a). Max Weber, too, supported Lukács's wish, ${ }^{68}$ as did the art historian Eberhard Gothein, but they could not overcome the resistance of other members of the faculty of philosophy. The application was rejected in December 1918 (for details see Bendl, 1998, p. 33; Demm, 1990; Loewy, 1999, pp. 278-279). ${ }^{69}$

The years in Heidelberg were highly fruitful for Lukács despite his abortive efforts to qualify for a professorship. From 1912 to 1914, he wrote a work that appeared posthumously in 1974 under the title Heidelberg Philosophy of Art. $\mathrm{He}$ himself had chosen not to publish the text, which he had produced during his pre-Marxist period. Nor did he publish a second text, "Heidelberg Aesthetics," which dates from 1916 to 1918 (Bendl, 1990).

In December 1918 Lukács joined the Communist Party of Hungary. Members of the Sunday Circle became leading cultural policy-makers under Béla Kun's Soviet Republic (on the cultural policies of the Hungarian Soviet Republic, see Borbándi, 1973; Gräfe, 2004; Karadi, 1986; Loewy, 1999). Lukács first became the commissar of trade (Gräfe, 2004, p. 894) and eventually deputy commissar of education, member of the Central Committee, chair of the Writers' Directorate, and political commissar of the Red Army's fifth division. As political commissar, Lukács ordered the execution of eight soldiers of the Hungarian Red Army in Poroszló for what in his estimation had been a failure to resist the Romanian attack on Tiszafüred (Kuzias, 2007, p. 128). ${ }^{70}$ Lukács allegedly also had deserters of the Hungary Red Army shot near Szolnok (p. 129). In a résumé composed in Moscow on December 2, 1940, he described his situation in Hungary at that time: "Hungary's White government persecuted me on account of more than 200 murders and demanded my extradition in order to carry out the death sentence imposed on me" (Kuzias, 2007, p. 129).

After the fall of the Hungarian Soviet Republic, Lukács worked for the party illegally in Budapest and Vienna between 1919 and 1929. He was the Hungarian Communist Party delegate to the Second and Third World Congresses of the Communist International in Moscow $(1920,1921)$ and a staff member working for the journals Communismus (Communism), Vörös Ujság (Red News), and Die Rote Fahne (The Red Flag). In 1923 Lukács published History and Class Consciousness, which became a key work of critical western Marxism and netted him fierce criticism as an ultra-leftist. His Theses Concerning the Political and Economic Situation in Hungary and the Tasks of the Hungarian Community Party were published in 1928. After expulsion from Austria in 1930, Lukács emigrated to Moscow, where he worked at the Marx-Engels-Lenin Institute. He stayed in Berlin from 1931 to 1933, where he was a member of the Bund proletarisch-revolutionärer Schriftsteller (Association of Proletarian-Revolutionary Authors) and the Schutzverband

\footnotetext{
${ }^{68}$ Max Weber was particularly enthusiastic about Lukács's (1920) book The Theory of the Novel.

${ }^{69}$ In 1911 Lukács had already failed at the University of Budapest in his attempt to seek certification as a qualified candidate for a professorship (Loewy, 1999, pp. 106-107). The same endeavor came to nothing in Düsseldorf as well (p. 174). In December 1915 Lukács repeatedly asked Max Weber whether there was some easier way to qualify for a university chair than by publishing a Habilitationsschrift—a second major work some years after the Ph.D. thesis (p. 277).

${ }^{70}$ Lukács's biographer, Kadarkay (1991), reported that only six of these eight men were summarily executed. One was pardoned, and another escaped (p. 223).
} 
deutscher Schriftsteller (Association for the Protection of German Authors) and where he worked with others on the journals Die Linkskurve and Internationale Literatur with (Benseler, 1987).

In 1933 Lukács re-emigrated to the Soviet Union. In Moscow he became a member of the Academy of Sciences of the USSR in 1934 and a staff member of the journals International Literature, Literaturnyj Kritik, Literarische Rundschau (as of 1936), and Deutsche Zentral-Zeitung (as of 1937). In the German section of the Soviet Writers' Association in Moscow, he was involved in Stalinist purges in September 1936. In 1941 he was held in the Lubjanka prison for two months by the People's Commissariat for Internal Affairs (NKWD, or secret police) and narrowly escaped the Great Terror. From 1938 to 1941 he was the chief editor of the Hungarian emigrants' journal Uj Hang (New Voice). In August 1945 Lukács moved back to Budapest, where he became a full professor of aesthetics and cultural philosophy. He was a member of the Hungarian parliament and the presidium of the Hungarian Academy of Sciences from 1949 to 1956. He played an inglorious role in the persecution of noncommunist intellectuals under the Stalinist regime led by Mátyás Rákosi. During the Hungarian revolution of October 1956, Lukács became the minister of education in the short-lived Communist government led by Imre Nagy, a reformist. After Soviet troops invaded Hungary on November 4, 1956, Lukács was deported to Romania but was permitted to reenter Hungary in 1957. He lived in internal emigration until 1965, ultimately rejoining the Communist Party under the Kádár regime. In his late work, translated into English as The Ontology of Social Being, Lukács attempted a comprehensive renewal of Marxism (Benseler, 1987).

Karl Mannheim (1893-1947), another compelling figure in the Sunday Circle, was briefly in Heidelberg during World War I ${ }^{71} \mathrm{He}$ received his doctorate in Budapest in 1918 and became a professor under the Hungarian Soviet Republic. When that republic ended, he passed briefly through Vienna and Freiburg im Breisgau before arriving in Heidelberg in March 1921. He soon established himself there with the help of Emil Lederer (1882-1939), the Heidelberg professor of public policy, and was registered as a student until the end of the winter semester of 1923-1924.

Originally, he intended to write his Habilitationsschrift at Heidelberg University in philosophy. This hope was dashed, however, by Heinrich J. Rickert (1863-1936) - an important exponent of neo-Kantianism. Mannheim therefore wrote his Habilitationsschrift under Alfred Weber, entitled Conservatism: A Contribution to the Sociology of Knowledge. His official supervisor was Emil Lederer, but the main inspiration came from Alfred Weber, who felt greater substantive affinity to Mannheim than Lederer did. Weber defended Mannheim against both an anti-Semitic faction in the faculty and political reservations about his erstwhile

\footnotetext{
${ }^{71} \mathrm{He}$ was not registered at Heidelberg University at that time, however.
} 
part in the Hungarian Soviet Republic (Demm, 2010, 2012; Karadi, 2003). ${ }^{72}$ After qualifying for a professorship, Mannheim taught at Heidelberg University as a Privatdozent ${ }^{73}$ from 1926 to 1930 . In 1930 he became a full professor of sociology and economics at the University of Frankfurt on the Main but had to leave Germany in 1933 because of his Jewish ancestry. He then took a post as professor at the London School of Economics and is known today for pioneering the sociology of knowledge (Kettler, Meja, \& Stehr, 1989).

\title{
Natural Scientists
}

Among the outstanding natural scientists from Hungary who studied in Heidelberg in the nineteenth and early twentieth centuries, Baron Loránd Eötvös (1848-1919) is unusually prominent (Fig. 3.14). His father, József Eötvös, had become the minister of culture in the first Hungarian government in March 1848. In 1866 he became the first president of the Hungarian Academy of Sciences, which he had reorganized, and after the Compromise of 1867 he served again as the minister of culture and education (for details about the Eötvös family, see Frank, 2012; Hübner, 2010).

Loránd Eötvös first studied law in Budapest from 1865 to 1867 . Károly Than ${ }^{74}$ (1834-1908), the founder of modern chemistry in Hungary, then motivated him to study chemistry in Heidelberg. As Loránd Eötvös noted in his memoires:

\begin{abstract}
While a student of the law, I entered, in 1867, among Károly Than's students. This was a decisive step in my career. It was from his lectures that the magic light of research into natural sciences shone at me for the first time, his-then still very small and defectivelaboratory was the first that opened up to me, and when I had performed the first chemical reaction, and had first sat in front of a balance, and when later my professor honoured me with allowing me an insight in his own investigations, then . . . I really learnt whatfollowing my scientific inclination-I can be good for in this homeland. (Quoted and translated by Vámos, 2006, p. 283)
\end{abstract}

\footnotetext{
${ }^{72}$ Details on the faculty's internal substantive and ideological disputes concerning Karl Mannheim's process of qualifying for a university chair and on the personal relationship between Alfred Weber and Karl Mannheim are found in Demm (1999, pp. 29-44; 2000a, 2000b, 2003, 2012), Kaesler (1990), and Karadi (2003).

${ }^{73}$ A Privatdozent at that time was a university lecturer who had absolved his or her Habilitation, which was a prerequisite of applying for a professorship at another university. If nominated by the faculty and proposed by the Senate of Heidelberg University, a university lecturer with Habilitation could, after six years of service, be promoted by the government to the status of associate professor not on the state payroll. No official post was attached to this title, however.

${ }^{74}$ Than had worked for a time as a postdoctoral researcher under Robert Wilhelm Bunsen in Heidelberg, where he had also met the physicist Gustav Robert Kirchhoff and the mathematician Moritz B. Cantor (1829-1920). At just 26 years of age, Than acquired a position as a substitute professor at the University of Pest and was offered a full professorship in chemistry at the age of 28. He served the Royal Hungarian Society for Natural Sciences as vice president (1862-1872) and president (1872-1880) (for more details see Vámos, 2006, p. 280).
} 

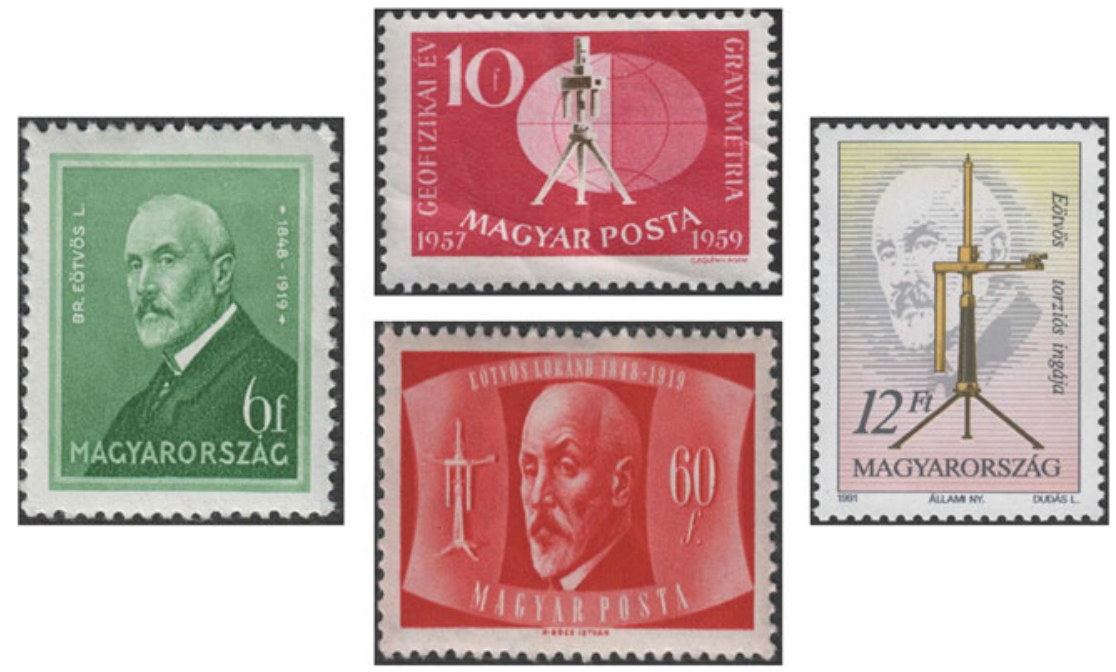

Fig. 3.14 The paramount role of Loránd Eötvös as an outstanding scientist is acknowledged in several ways. The Hungarian post office has dedicated four stamps to him $(1932,1948,1959$, and 1991), he has been nominated for the Nobel Prize three times (1911, 1914, and 1917), and Hungary's most important university was named after him in 1950.

Source: Picture collection of Postakürt Alapítvány Bélyegmúzeum, Budapest. Reprinted with permission.

Loránd Eötvös arrived in Heidelberg on October 3, 1867, and registered in chemistry on October 21. His father was well acquainted with the Heidelberg law professors Karl Adolf von Vangerow (1808-1870), Johann Kaspar Bluntschli (1808-1881), and Karl Theodor Welcker (1790-1869) as well as with Bunsen and Kirchhoff, so Loránd was well received privately, too, not least because of his manifest academic zeal (Hübner, 2010, p. 200). The younger Eötvös found the chemistry lectures by Bunsen "not exactly dazzling" but thought a great deal of him nevertheless. By contrast, Kirchhoff's personality and lectures impressed Eötvös so much that he majored in physics. Lastly, the lectures of the geologist and associate professor Gustav Alfons von Leonhard (1816-1878) sparked his interest in geophysics. Kirchhoff advised Loránd to switch to professors Franz E. Neumann (1798-1895) and Friedrich J. Richelot (1808-1875) at the University of Königsberg. The young Eötvös spent the summer semester of 1869 there, returning to Heidelberg in the fall of 1869 (Hübner, 2010, pp. 198-207). On July 8,1870 , he graduated summa cum laude from Heidelberg.

From 1870 until his death, Loránd Eötvös researched and taught at the University of Budapest. He was particularly interested in capillarity, gravitation, and geomagnetism and formulated what is now known as Eötvös's law (Eötvös, 1886), which dealt with the relation between the surface tension of fluids at different temperatures and molecular weight (see also Einstein, 1911). In 1890 Eötvös developed a dynamic method of measuring the gravitational constant, later constructed a gravimeter and the Eötvös torsion balance, which could detect the presence of crude oil in anticlines. Eötvös served as the rector of the university (1891-1892), minister of culture (1894-1895), and president of the Hungarian Academy of Sciences (1889-1905). 
The physicist and cultural historian Ágost Heller (1843-1902) was already a graduate student when he registered at Heidelberg University. In 1866 he had completed training as a railroad engineer at the Joseph Polytechnic in Buda, where he worked as an assistant in the two years thereafter. He studied physics under Kirchhoff and Hermann Ludwig Ferdinand von Helmholtz in 1869. Between 1870 and 1898 he taught physics at a public secondary school in Budapest. Beginning in 1875 he worked as a librarian for the Natural Science Association. The Hungarian Academy of Sciences elected him as corresponding member in 1887 and as a full member in 1893, employing him as the head librarian as of 1894. He authored numerous textbooks, technical articles, and works of popular science. He became known especially through his two-volume History of Physics from Aristotle to Today (1882-1884). Heller was one of the editors and authors of the 16-volume Pallas Nagy Lexikon, the first Hungarian encyclopedia not based on a translation.

Kálmán Szily (1838-1924) was the son of a landed nobleman and already had a degree from the Vienna Polytechnic Institute when he studied physics, first in Berlin and then, beginning in 1865, under Kirchhoff in Heidelberg. He also distinguished himself as a scholar, cultural policy expert, and organizer. For decades he held the chair of experimental physics at the Joseph Polytechnic in Buda, which became the Technical University of Buda in $1871^{75}$ and he its first rector. Under the president of the Hungarian Academy of Sciences, Loránd Eötvös, Szily was the academy's general secretary from 1889 to 1905 . He reformed the institution's publishing and created the Natural Science Bulletin (Természettudományi Közlöny). He later became the head librarian of the Academy of Sciences and both the founder and president of the Hungarian Linguistic Society.

Vince Wartha (1844-1914) was born in Fiume, attended the Gymnasium in Szeged, then the Joseph Polytechnic in Buda. He thereafter studied at the Eidgenössische Technische Hochschule (Swiss Federal Institute of Technology, ETH) in Zurich, where he completed his first degree (Diplom) in 1864. Back in Hungary, he received an assistantship in the chemistry department of the Joseph Polytechnic. He was dissatisfied with the situation, however, and went to Heidelberg, where he graduated with a doctorate under Bunsen in 1865. After taking up residence again in Zurich, he worked as an assistant and Privatdozent at the Institute of Chemistry from 1865 to 1867 . In 1867 he accepted the chair of mineralogy and geology at the Joseph Polytechnic. In 1871 Wartha took over the chair of chemical technology at the new Technical University, a post he held for the next 41 years. He served as dean of the Technical University of Budapest (1875-1877) and as rector (1896-1898 and 1907-1910).

Wartha's most significant innovation was the rediscovery of the long-lost secret of producing the iridescent metallic sheen for which the medieval enamels from the Italian town of Gubbio have been known for centuries. Working together with Vilmos Zsolnay, Wartha developed the technique of using eosin to refine ceramics. In Zsolnay's factory in Pécs, the process was applied to ornamental objects for the

\footnotetext{
${ }^{75}$ The Joseph Polytechnic, established in 1856, became the Royal Joseph University in 1862. It was among the first institutions in Europe to train engineers at the university level. In 1872 it gained full autonomy and the right to issue engineering diplomas. In 1901 it was entitled to confer the doctoral degree.
} 
first time. The eosin enamel ceramics by Zsolnay became a world famous stylistic element of Hungarian art nouveau. Wartha also participated as a ceramics expert in founding the Museo Internazionale delle Céramiche (International Musuem of Ceramics) in Faenza, Italy. He developed a particular method of alkalimetry (the determination of the amount of alkali or base in a solution, measured by an alkalimeter or by volumetric analysis) and, together with Ignác Pfeifer, a way of determining water hardness. In 1873 he became a corresponding member of the Hungarian Academy of Sciences; in 1893, a full member of that organization; and from 1909 on, its vice president.

Alajos Schuller (1845-1920) began studying at the Joseph Polytechnic in Buda in 1863 and worked there as an assistant after graduating. He then went to Heidelberg and studied chemistry under Bunsen and physics under Kirchhoff from 1870 to 1872 , serving as the latter's assistant (1871-1872). From 1872 to 1916 Schuller held the chair of experimental physics at the Technical University of Budapest. Schuller focused scientifically on calorimetric experiments, sometimes working with his friend Vince Wartha. He improved on Bunsen's calorimeter and developed an automatic mercury air pump himself. In honor of achievements, he received the status of a corresponding member of the Hungarian Academy of Sciences in 1880, and an honorary doctorate from the University of Klausenburg (Kolozsvár) in 1910.

Gyula (Julius) König (1848-1913) began studying medicine in Heidelberg in 1868 , then turned to physics. After working with Helmholtz on the electrical stimulation of nerves, König completed his doctorate in 1870, writing a 24-page dissertation entitled Zur Theorie der Modulargleichungen der elliptischen Functionen (The Theory of Modular Equations of Elliptical Functions) under the Heidelberg mathematician Leo Königsberger. In 1874 he became a professor at the Technical University of Budapest, where he worked for the rest of his life, also serving three terms each as dean and rector. In 1889 he became a member of the Hungarian Academy of Sciences. In addition to articles on analysis and number theory, his works on algebra and Cantor's set theory were particularly important (König's theorem). His Einleitung in die allgemeine Theorie der algebraischen Größen (Introduction to the General Theory of Algebraic Magnitudes; König, 1903) made him a precursor of modern algebra. ${ }^{76}$

The high level of research and teaching at the young Technical University of Budapest was largely due to four renowned professors who had studied or had received their doctorates at almost the same time in Heidelberg: the physicists Szily and Schuller, the chemist Wartha, and the mathematician König. These four natural

\footnotetext{
76،'In 1904, at the third International Congress of Mathematicians at Heidelberg, König gave a talk to disprove Cantor's continuum hypothesis. The announcement was a sensation and was widely reported by the press. All section meetings were cancelled so that everyone could hear his contribution. König applied a theorem proved in the thesis of Felix Bernstein; this theorem, however, was not as generally valid as Bernstein had claimed. Ernst Zermelo,, the later editor of Cantor's collected works, found the error already the next day. In 1905 there appeared short notes by Bernstein, correcting his theorem, and König withdrawing his claim.” Retrieved February 2, 2017, from https://en.wikipedia.org/wiki/Gyula_K\%C5\%91nig.
} 
scientists were occasionally called simply "the Heidelbergians" by their fellow academics in Hungary.

After graduating from the Joseph Polytechnic in Buda in 1866, Béla Lengyel (1844-1913) studied chemistry, first at the university in Pest and then under Bunsen in Heidelberg, where he was Bunsen's assistant (1869-1870). He qualified for a university professorship in 1870, was appointed as a Privatdozent in 1871, an assistant professor in 1872, and a full professor of experimental, analytical, and organic chemistry at the University of Budapest. He was dean of the philosophical faculty from 1885 to 1886 and rector of the university from 1895 to 1896 . From 1863 to 1893 , Lengyel was secretary of the Hungarian Natural Science Society. He became a corresponding member of the Hungarian Academy of Sciences in 1876 and a full member in 1894. He discovered carbon subsulfide $\left(\mathrm{C}_{3} \mathrm{~S}_{2}\right)$, among other things, and became known for his research on subjects such as the spectroscopy of gas mixtures, radioactivity, and theoretical principles underlying phenomena of light in evacuated pipes during the passage of electrical current.

Béla Issekutz (1886-1979) received a doctorate in medicine at the University of Kolozsvár and registered in 1913 as an intern in Heidelberg. He became a professor in Kolozsvár in 1918, professor and rector in Szeged in 1920, and professor and director of the pharmacological department in the medical faculty in Budapest in 1937. He introduced modern pharmacological research into Hungary and succeeded, among other things, at explaining the mechanism of action of insulin and thyroxin. He helped pioneer the use of chemotherapy against cancer.

Philipp Lenard (Fülöp Lenárd, 1862-1947) was the son of a Tirol wine dealer in Pressburg (Pozsony, today's Bratislava). After attending the Hungarian Gymnasium in Pressburg, he studied natural science at the universities of Budapest and Vienna for two semesters in 1880, then worked in his father's wine dealership in Pressburg. In 1883 he resumed his studies in Heidelberg under Georg Hermann Quincke (1834-1924) and Robert Bunsen. After one semester under Helmholtz in Berlin, he earned his doctorate in Heidelberg, writing his dissertation on the Über die Schwingung fallender Tropfen (On the oscillation of falling water drops). Lenard served briefly an assistant to Loránd Eötvös at the University of Budapest (1887). From 1887 to 1890 he was an assistant under Quincke in the physics department at the University of Heidelberg, where he continued his investigations on phosphorescence. In 1891 he went to Breslau and, as an assistant to Heinrich Hertz, moved to Bonn in 1892. There, Lenard completed his qualification for a professorship in 1893 with his postdoctoral dissertation entitled Über die Elektricität der Wasserfälle (On the electricity of waterfalls). He also studied cathode rays. From his own collection he supplied Conrad Röntgen with a discharge tube and a Lenard window, both of which proved decisive in the discovery of x-rays in 1895. After Röntgen became famous for this discovery, Lenard accused him of having stolen it. Lenard became an associate professor in Breslau in the winter semester of 1894-1895, a lecturer at the Technical University of Aachen in the winter semester of 1895-1896, an associate professor in Heidelberg in the winter semester of 1896-1897, and a full professor and director of the physics department at the University of Kiel in the summer semester of 1898 . 
Lenard received the 1905 Nobel prize for physics for his work on cathode rays and the development of electron theory. In 1907 he succeeded his teacher, Quincke, as a full professor of physics and radiology at Heidelberg University and as the director of the physics department there. In 1907 he acquired German citizenship as well. In 1913 he expanded the Heidelberg radiology department into the largest and most modern physics department in Germany. He declined a call to the University of Pressburg in 1914. In 1932 he received the Benjamin Franklin Medal, a highly endowed scientific award conferred by the American Franklin Institute in Philadelphia. Lenard was a member of the scientific academies in Heidelberg, Berlin, and Vienna and received an honorary doctorate in engineering from the Technical University of Dresden. In 1928 he became a public supporter of the racially minded, anti-Semitic convictions of the National Socialist Society for German Culture. He opposed Einstein, rejected relativity theory and quantum mechanics as too abstract and unrealistic, and espoused "German physics."

Some prominent Hungarians did not study at Heidelberg University but accepted a chair there. Their circle included two professors of ancient history-Alfred von Domaszewski (1856-1927) and Géza Alföldy (1935-2011)—anatomist Count Béla Haller von Hallerstein (1858-1914), physician Pál György (1893-1976), ${ }^{77}$ and zoologist József Spek (1895-1964). ${ }^{78}$

\footnotetext{
${ }^{77}$ György left Heidelberg University at his own request for political reasons in 1933. In England he carried out research at the Nutrition Laboratory of Cambridge University from 1933 to 1935. In the United States in 1935, he became a visiting assistant professor of pediatrics at the medical school of the Western Reserve University in Cleveland, Ohio, and was named associate professor there in 1937. He assumed the post of associate research professor of pediatrics at the University of Pennsylvania School of Medicine in 1944 and became a full professor in 1946. From 1950 to 1957, he served as the head of pediatrics at Philadelphia General Hospital. He became internationally known through his discovery of three vitamins: riboflavin, vitamin B6, and biotin (vitamin B7, formerly known as vitamin $\mathrm{H}$ or coenzyme R). In 1959 he received an honorary doctorate from Heidelberg University. U. S. President Gerald Ford awarded him a posthumous National Medal of Science in the biological sciences "for his discovery of three vitamins and related research that have greatly improved human nutrition" (Retrieved March 2, 2017, from https://www.nationalmedals. org/laureates/paul-gyorgy\#).

${ }^{78}$ Spek worked from 1932 to 1933 in the laboratory of the cellular physiologist and biophysicist Robert Chambers in New York and in Woods Hole, Massachusetts. After teaching during an interim professorship at the University of Greifswald (1943-1944) and turning down a call to the University of Halle (1946), he accepted an appointment as a full professor of zoology at the University of Rostock (1947). He was particularly interested in questions of cell structure. New detection methods that Spek developed made him a pioneer of vital staining and fluorescent marking in microscopy. As one of the leading researchers of protoplasm, he was a cofounder of the international journal Protoplasm.
} 


\section{Stagnation and a Fresh Beginning of Scientific Relations}

After the National Socialists seized power in Germany in January 1933, an extraordinary intellectual period at Heidelberg University abruptly ended, the hitherto worldwide area for recruiting students and professors shrank radically, and the number of Hungarian students plummeted. But some of the origins of this demise dated back more than a decade. First, the Treaty of Trianon, signed in 1920 to formally end World War I between most of the Allies and Hungary, had stripped Hungary of two thirds of its territory and had passed those lands to neighboring countries. Students from those areas therefore no longer counted as Hungarians in the statistics on nationalities. Second, the onset of the Great Depression in 1929 made university study in Germany unattractive, a situation that only worsened under National Socialism (1933-1945) and during World War II (1939-1945).

For decades following World War II, the Communist regime blocked Hungarians from studying in the West at all. In the more than 500 years of scientific relations between Germany and Hungary, there has never been a period in which Hungarian students and scholars were as hermetically isolated from the West as they were during the Cold War. Only as of 1961 were a few Hungarian scientists of the young generation permitted to enter the Federal Republic of Germany temporarily (e.g., on a research fellowship from the Alexander von Humboldt Foundation or the German Academic Exchange Service [DAAD]). An initial, cautious rapprochement between Heidelberg University and the Eötvös Loránd University in Budapest in the early 1980s led in 1983 to an agreement on a partnership between them-Heidelberg's first such arrangement with a university in the Communist Bloc (for details, see Meusburger, 2003).

The signing of the partnership agreement opened new doors for scientists from the Eötvös Loránd University to conduct research in Heidelberg and cooperate with academics at the university there. These opportunities were taken primarily by scholars of law, medicine, and geography (for details see Meusburger, 2003). The Heidelberg visit by the Hungarian law professors Ferenc Mádl (1931-2011) and Lajos Vékás (1939- ) in 1983 was to have especially intense, long-term impacts. Together with their colleagues László Sólyom (1942- ) and János Németh (1933- ) and the Heidelberg jurists Erik Jayme and Gert Reinhart, Mádl and Vékás launched joint seminars with German and Hungarian students of civil law, corporate law, international contract law, copyright law, and a host of other subjects that were crucial when the market economy was introduced in Hungary later. The courses proved to be a highly advantageous head start in the training of Hungary's aspiring young lawyers.

These four far-sighted Hungarian professors of law rose to the highest offices after the collapse of the Communist regime in 1989. Mádl, who came from a Hungarian-German family in Bánd (western Hungary), was the government minister (without portfolio) of science policy and the coordination of government policy. From 1990 to 1992 he also functioned as a board chairman of the state property agency, which oversaw the banking sector. He served as minister of culture from 
1993 to 1994 and was elected as the president of Hungary in May 2000, although he had no party affiliation. President Mádl received an honorary doctorate from Heidelberg University in July 2001.

Lajos Vékás, one of the first contacts involved in 1983, spent 1987 in Heidelberg on a Humboldt fellowship. He became rector of the Eötvös Loránd University (1990-1993), rector of the Budapest Collegium (1992-1997), and a member of the Foundation and Academic Council of the Europe Institute Budapest. In 2014 he became vice president of the Hungarian Academy of Sciences.

László Sólyom was appointed as first president of the Hungarian Constitutional Court (1990-1998) after the democratic transformation of the political system that had begun in late 1989 and was later elected as state president (2005-2010). János Németh became the executive president of the Constitution Court (1998-2003). Kálmán Györgyi (1939- ), the cooperating partner of the Heidelberg criminal law expert and criminologist Olaf Miehe (1935-), was appointed as the first attorney general of democratic Hungary after the collapse of the communist regime.

However, Hungary's cautious opening to the West before the final debacle of the communist regime was confined largely to scholars. Hungarian students had to wait several years more before they were allowed to study in Germany (partly for financial reasons, too). The 20 to 30 Hungarian nationals who studied in Heidelberg in the 1980s, most of them children of Hungarian refugees who had fled the country in 1956, were already living outside Hungary. The number of Hungarian students in Heidelberg did not recover strongly until after the opening of the East-West border in 1989 and the collapse of the communist regime in the course of 1990. It initially peaked at more than 100 students in the 2002-2003 academic year.

\section{Conclusion}

This chapter has documented that the intellectual appeal of a university and the area from which its professors and students come has historically depended on numerous scientific, political, economic, confessional, organizational, and cultural factors of influence. Heidelberg University has had heydays that made it an important intellectual and scientific center, and it has intermittently suffered catastrophes relegating it to irrelevance. Again and again, periods of internationality and outstanding scientific achievements have been succeeded by academic mediocrity; intellectual freedom, by political interference. This narrative highlights the exceptional role that the international networks and web of relations cultivated by individual famous scholars have repeatedly played over the centuries for the areas from which foreign students are recruited. It underscores how much an internationally oriented university such as Heidelberg has been marked by pan-European political power relations, foreign-policy interests, diplomatic relations, wartime events, and confessional disputes. It also emphasizes how much an intellectually powerful university can serve as a first-class innovative space capable of affecting the cultural, economic, 
and sometimes even political development of far-flung regions through its students and the networks of its professors.

Place, networks, and spatial relations matter. Few fields of endeavor, if any, reflect the pertinence of this statement as obviously as science does. The structural contexts, interrelations, and web of interests that frame research and teaching; the place experience of students; the ebb and flow of a university's intellectual aura and attractiveness; and the significance of universities in the development of international networks therefore pose interesting questions for research at various levels of aggregation.

Another scientific challenge is the research question of the effects that studying in a foreign country may have on the society, culture, and scientific community in the country from which the students and aspiring young academics hail. The fact that so many Hungarian students studied outside their country in different eras has clearly contributed to pronounced internationalism, superb foreign-language skills in academic occupations, and impressive cultural and scientific dynamics in Hungary during some bright periods of its history. On the other hand, totalitarian political regimes or forced isolation during hot and cold wars lead inevitably to the loss of international contacts and all the above-mentioned benefits, resulting in decay of intellectual vigor and deterioration in the quality of life as well.

\section{References}

Ábel, J. (1881). Egyetemeink a középkorban [Our medieval universities]. Budapest: MTA Irodalomtörténeti Bizottsága. Retrieved from http://www.mek.oszk.hu/10800/10825/

Almási, G. (2014). Touring Europe: Comparing east-central European academic peregrination in the sixteenth and seventeenth century. In G. Almási (Ed.), Study tours and intellectual-religious relationships (pp. 17-34). A divided Hungary in Europe: Exchanges, networks and representations, 1541-1699: Vol. 1. Cambridge, UK: Cambridge Scholar Publishing.

Altmann, J. (1997). Die mittelalterliche Universität in Óbuda (Altofen) [The medieval university in Óbuda (Altofen)]. In L. Szögi \& J. Varga (Eds.), Universitas Budensis, 1395-1995: International conference for the history of universities on the occasion of the 600th anniversary of the foundation of the University of Buda (pp. 67-74). Budapest: Eötvös Loránd University Library and Archive.

Alvermann, D. (2006). Stipendien als strukturelle Elemente des Migrationsnetzes. Das Beispiel Greifswald [Scholarships as structural elements of the migration network: The example of Greifswald]. In M. Fata, G. Kurucz, \& A. Schindling (Eds.), Peregrinatio Hungarica. Studenten aus Ungarn an deutschen und österreichischen Hochschulen vom 16. bis zum 20. Jahrhundert (pp. 345-384). Contubernium-Tübinger Beiträge zur Universitäts- und Wissenschaftsgeschichte: Vol. 64. Stuttgart: Steiner.

Anderegg, J.-P. (2000). Siebenbürgen: Kolonistenland am Rande Europas [Transylvania: Land of colonists at Europe's edge]. Freiburger Geschichtsblätter, 77, 177-190.

Andritsch, J. (1965). Studenten und Lehrer aus Ungarn und Siebenbürgen an der Universität Graz (1586-1782) [Students and teachers from Hungary and Transylvania at the University of Graz (1586-1782)]. Graz: Historische Landeskommission.

Asche, M. (2004). Bildungsbeziehungen zwischen Ungarn, Siebenbürgen und den deutschen Universitäten im 16. und frühen 17. Jahrhundert [Educational relations between Hungary, Transylvania, and German universities in the sixteenth and early seventeenth centuries]. In 
W. Kühlmann \& A. Schindling (Eds.), Deutschland und Ungarn in ihren Bildungs- und Wissenschaftsbeziehungen während der Renaissance (pp. 27-52). Contubernium-Tübinger Beiträge zur Universitäts- und Wissenschaftsgeschichte: Vol. 62. Stuttgart: Steiner.

Asche, M. (2010). Philipp Melanchthon als christlicher Schulhumanist und Bildungsreformer: Wittenberg und der Export des humanistischen Bildungsprogramms [Philipp Melanchthon as a Christian school humanist and educational reformer: Wittenberg and the export of the humanist educational program]. In F. Schweitzer, S. Lorenz, \& E. Seidl (Eds.), Philipp Melanchthon: Seine Bedeutung für Kirche und Theologie, Bildung und Wissenschaft (pp. 75-94). Theologie Interdisziplinär: Vol. 8. Neukirchen-Vluyn: Neukirchener Verlagsgesellschaft

Baar-Cantoni, R. (2012). Martin Luther's disputation in Heidelberg and its widespread effects. In P. Meusburger \& T. Schuch (Eds.), Wissenschaftsatlas of Heidelberg University: Spatiotemporal relations of academic knowledge production (pp. 56-57). Knittlingen: Bibliotheca Palatina.

Baar-Cantoni, R., \& Wolgast E. (2012). Migration of professors between 1550 and 1700. In P. Meusburger \& T. Schuch (Eds.), Wissenschaftsatlas of Heidelberg University: Spatiotemporal relations of academic knowledge production (pp. 66-69). Knittlingen: Bibliotheca Palatina.

Barta, I. (1937). Ungarn und die Wiener Universität des Jesuitenzeitalters [Hungary and the University of Vienna in the Jesuit age]. A Gróf Klebelsberg Kunó Magyar Történetkutató Intézet évkönyve, 7, 113-177.

Bartha, T. (Ed.). (1967). Der Heidelberger Katechismus in Ungarn [The Heidelberg Catechism in Hungary]. Budapest: Presseabteilung der Synodalkanzlei der reformierten Kirche in Ungarn.

Beck, A. J. (Ed.). (2016). Melanchthon und die Reformierte Tradition [Melanchthon and the Reformed tradition]. Refo500 Academic Studies: Vol. 6. Göttingen: Vandenhoeck \& Ruprecht.

Bencsik, P. (2002). Útiokmányok, utazási lehetôségek, idegenforgalom a 20. századi Magyarországon [Travel documents, opportunities, and tourism in twentieth-century Hungary]. Regio, 13(2), 31-50. Retrieved from epa.oszk.hu/00000/00036/00045/pdf/02.pdf

Benda, K. (1976). La réforme en Hongrie [Reformation in Hungary]. Bulletin de la Societé de l'histoire de Protestantisme Français, 122, 30-53.

Bendl, J. (1990). Die wiedergefundene Heidelberger Bibliothek von Georg Lukács [The recovered library of George Lukács]. Hungarian Studies, 6, 173-184.

Bendl, J. (1998). Zwischen Heirat und Habilitation in Heidelberg [Between marriage and habilitation in Heidelberg]. Jahrbuch der Internationalen Georg-Lukács-Gesellschaft 1997, 2, 17-45.

Benseler, F. (1987). Lukács, Georg. In Neue Deutsche Biographie: Vol. 15. Locherer-Maltza(h)n (pp. 509-513). Berlin: Duncker \& Humblot. Retrieved from http://www.deutsche-biographie. de/pnd11857518X.html

Bernhard, J.-A. (2010). Calvins Wirkung und Einfluss in Ungarn und Siebenbürgen vor 1551 [Calvin's impact and influence in Hungary and Transylvania before 1551]. In M. Fata \& A. Schindling (Eds.), Calvin und Reformiertentum in Ungarn und Siebenbürgen. Helvetisches Bekenntnis, Ethnie und Politik vom 16. Jahrhundert bis 1918 (pp. 25-62). Reformationsgeschichtliche Studien und Texte: Vol. 155. Münster: Aschendorff.

Bernhard, J.-A. (2015). Konsolidierung des reformierten Bekenntnisses im Reich der Stephanskrone: Ein Beitrag zur Kommunikationsgeschichte zwischen Ungarn und der Schweiz in der frühen Neuzeit (1500 - 1700) [Consolidation of the Reformed Confession in the lands of Saint Stephen's Crown: A contribution to the communication history between Hungary and Switzerland in the Early Modern Age (1500-1700)]. Refo500 Academic Studies: Vol. 19. Göttingen: Vandenhoeck \& Ruprecht.

Bethlen, M. (1955). Önéletírása [Memoires]. Budapest: Szépirodalmi. Retrieved from http://www. mek.oszk.hu/06100/06152/html/bethlen0020001.html

Bierma, L. D. (2015). The theological origins of the Heidelberg Catechism. In C. Strohm \& J. Stievermann (Eds.), Profil und Wirkung des Heidelberger Katechismus: Neue Forschungsbeiträge anläßlich des 450jährigen Jubiläums. The Heidelberg Catechism: Origins, 
characteristics, and influences: Essays in reappraisal on the occasion of its 450th anniversary (pp. 13-22). Schriften des Vereins für Reformationsgeschichte: Vol. 215. Gütersloh: Gütersloher Verlagshaus.

Binder, P. (1975). Kulturaustausch in Siebenbürgen auf dem Gebiet des Buchdrucks [Cultural exchange in Transylvania in the field of printing]. In P. Philippi (Ed.), Siebenbürgen als Beispiel europäischen Kulturaustausches (pp. 71-90). Siebenbürgisches Archiv: Vol. 12. Cologne: Böhlau.

Birkenmaier, W. (2012). World revolution, Zionism and emigration: Students from the Russian Empire. In P. Meusburger \& T. Schuch (Eds.), Wissenschaftsatlas of Heidelberg University: Spatio-temporal relations of academic knowledge production (pp. 300-303). Knittlingen: Bibliotheca Palatina.

Black, J. (1983). France and the Grand Tour in the early eighteenth century. Francia, 11, 407-416. Black, J. (1992). The British abroad: The Grand Tour in the eighteenth century. Stroud: Sutton.

Bodrogi, B., \& Galántai, Z. (2013). Gazdaságtörténet [Economic history]. Budapest: Typotex.

Borbándi, G. (1973). Die Kulturpolitik der ungarischen Räterepublik [Cultural politics of the Hungarian soviet republic]. Ungarn-Jahrbuch, 5, 171-186.

Bozzay, R. (2010). Der Einfluss ehemaliger Studenten der Leidener Universität im 17. und 18. Jahrhundert auf Kultur und Bildung in Siebenbürgen [The influence of former students of Leiden University in the seventeenth and eighteenth centuries on culture and education in Transylvania]. In M. Fata \& A. Schindling (Eds.), Calvin und Reformiertentum in Ungarn und Siebenbürgen: Helvetisches Bekenntnis, Ethnie und Politik vom 16. Jahrhundert bis 1918 (pp. 215-238). Reformationsgeschichtliche Studien und Texte: Vol. 155. Münster: Aschendorff.

Bozzay, R. (2014). The influence of Dutch universities on the education of seventeenth-century Hungarian intellectuals. In G. Almási (Ed.), Study tours and intellectual-religious relationships (pp. 81-100). A divided Hungary in Europe: Exchanges, networks and representations, 15411699: Vol. 1. Cambridge, UK: Cambridge Scholar Publishing.

Brenner, R. (1989). Economic backwardness in eastern Europe in light of developments in the west. In D. Chirot (Ed.), The origins of backwardness in eastern Europe: Economics and politics from the Middle Ages to the early twentieth century (pp. 15-52). Berkeley: University of California Press.

Bucsay, M. (1977). Der Protestantismus in Ungarn 1521-1978: Ungarns Reformationskirchen in Geschichte und Gegenwart. Teil 1. Im Zeitalter der Reformation, Gegenreformation und katholischen Reform [Protestantism in Hungary, 1521-1978: Hungary's Reformed churches in history and presence: Part 1. In the age of Reformation, Counter-Reformation, and Catholic reform]. Studien und Texte zur Kirchengeschichte und Geschichte: Reihe 1, Vol. 3. Vienna: Böhlau.

Chaney, E. (1998). The evolution of the Grand Tour: Anglo-Italian cultural relations since the Renaissance. London: Cass.

Clifford, J. (1992). Travelling cultures. In L. Grossberg, C. Nelson, \& P. Treichler (Eds.), Cultural studies (pp. 96-116). London: Routledge.

Comenius, J. A. (1668/1958). Unum necessarium: The one thing necessary [or: The one thing Needful] (V. H. Nelson, Trans.). Winston-Salem: Moravian Archives. Retrieved from http:// moravianarchives.org/images/pdfs/Unum\%20Necessarium.pdf

Comenius, J. A. (1705). Visible world, or, a nomenclature, and pictures of all the chief things in the world and mens employments therein (C. Hoole, Trans.). London: n.p. (Original work published 1658: Orbis sensualium pictus: Hoc est, omnium princip omnium principalium in mundo).

Courtenay, W. J. (2000). Study abroad: German students at Bologna, Paris, and Oxford in the fourteenth century. In W. J. Courtenay \& J. Miethke (Eds.), Universities and schooling in medieval society (pp. 7-31). Education and Society in the Middle Ages and Renaissance: Vol. 10. Leiden: Brill.

Csizmadia, A. (1965). Die Universität Pécs im Mittelalter (1367- ) [The university of Pécs in the Middle Ages (1367- )]. Studia Iuridica: Auctoritate Universitatis Pécs Publicata: Vol. 41. Budapest: Tankönyvkiado. 
Csohány, J. (1994-1995). Die politischen Beziehungen von Gábor Bethlen zum reformierten Europa [Political relations of Gábor Bethlen to Protestant Europe]. Jahrbuch für die Geschichte des Protestantismus in Österreich, 110/111, 87-98.

Czettler, A. (1980-1981). Die Außenpolitik der Siebenbürgischen Prinzen im 16. und 17. Jahrhundert [Foreign policy of Transylvanian Princes in the sixteenth and seventeenth centuries]. Ungarn-Jahrbuch, 11, 91-121.

de Ridder-Symoens, H. (1996). Mobility. In H. de Ridder-Symoens (Ed.), Universities in early modern Europe (1500-1800) (pp. 416-448). A history of the university in Europe: Vol. 2. Cambridge, UK: Cambridge University Press.

Demm, E. (1990). Ein Liberaler in Kaiserreich und Republik: Der politische Weg Alfred Webers bis 1920 [A liberal in the empire and the republic: The political path of Alfred Weber until 1920]. Schriften des Bundesarchivs: Vol. 38. Boppard: Boldt.

Demm, E. (1999). Von der Weimarer Republik zur Bundesrepublik: Der politische Weg Alfred Webers von 1920 bis 1958 [From the Weimar Republic to the Federal Republic: The political path of Alfred Weber from 1920 to 1958]. Schriften des Bundesarchivs: Vol. 51. Düsseldorf: Droste.

Demm, E. (2000a). Ein „Institut der Außenseiter“? Historische Forschung und Personalpolitik am Heidelberger Staatswissenschaftlichen Institut unter Eberhard Gothein und Alfred Weber (1904-1933) [A department of "outsiders"? Historical research and personal politics at the Heidelberg Institut of Political Science under Eberhard Gothein and Alfred Weber (1904-1933)]. In E. Demm (Ed.), Geist und Politik im 20. Jahrhundert: Gesammelte Aufsätze zu Alfred Weber (pp. 129-183). Frankfurt am Main: Lang

Demm, E. (2000b). Karl Mannheim und Alfred Weber [Karl Mannheim and Alfred Weber]. In E. Demm (Ed.), Geist und Politik im 20. Jahrhundert: Gesammelte Aufsätze zu Alfred Weber (pp. 251-266). Frankfurt am Main: Lang

Demm, E. (2003). Karl Mannheim és Alfred Weber: Alfred Weber és Heinrich Rickert között [Karl Mannheim and Alfred Weber: Between Alfred Weber and Heinrich Rickert]. In L. C. Kiss, M. G. Lázár, E. Karádi, K. Mannheim, \& N. Elias (Eds.), Mannheim-tanulmányok: Írások Mannheim Károlytól és Mannheim Károlyról (pp. 111-128). Budapest: Napvilág.

Demm, E. (2010). Alfred Weber (1868-1958): Machtkapital, Netzwerke und Lebensstil [Alfred Weber (1868-1958): Power capital, networks, and life style]. In E. Demm \& J. Suchoples (Eds.), Akademische Lebenswelten: Habitus und Sozialprofil von Gelehrten im 19. und 20. Jahrhundert (pp. 105-135). Frankfurt am Main: Peter Lang.

Demm, E. (2012). Alfred Weber and his disciples. In P. Meusburger \& T. Schuch (Eds.), Wissenschaftsatlas of Heidelberg University: Spatio-temporal relations of academic knowledge production (pp. 114-115). Knittlingen: Bibliotheca Palatina.

Dézsi, L. (1897). Szenczi Molnár Albert 1574-1634 [Albert Szenczi Molnár 1574-1634]. Budapest: Magyar Történelmi Társulat. Retrieved from http://www.mek.oszk.hu/05600/05617/html/

Diener, H. (1963). Zur Geschichte der Universitätsgründungen in Alt-Ofen (1395) und Nantes (1423) [On the history of the founding of the university in Óbuda (1395) and Nantes (1423)]. Quellen und Forschungen aus italienischen Archiven und Bibliotheken, 42-43, 265-284.

Domonkos, L. (1997). The founding (1395) and refounding (1410) of the University of Óbuda. In L. Szögi \& J. Varga (Eds.), Universitas Budensis, 1395-1995: International conference for the history of universities on the occasion of the 600th anniversary of the foundation of the University of Buda (pp. 19-34). Budapest: Eötvös Loránd University Library and Archive.

Dotzauer, W. (1977). Deutsches Studium und deutsche Studenten an europäischen Hochschulen (Frankreich, Italien) und die nachfolgende Tätigkeiten in Stadt, Kirche und Territorium in Deutschland [German studies and German students at European universities (France, Italy) and subsequent employment in town, church, and territory]. In E. Maschke \& J. Sydow (Eds.), Stadt und Universität im Mittelalter und in der früheren Neuzeit (pp. 112-141). Stadt in der Geschichte: Vol. 3. Sigmaringen: Jan Thorbecke.

Driver, F. (2001). Geography militant: Cultures of exploration and empire. Oxford, UK: Blackwell 
Driver, F. (2017). Exploration as knowledge transfer: Exhibiting hidden histories. In H. Jöns, P. Meusburger, \& M. Heffernan (Eds.), Mobilities of knowledge (pp. 85-104). Knowledge and Space: Vol. 10. Dordrecht: Springer. doi:https://doi.org/10.1007/978-3-319-44654-7_5

Duncan, J., \& Gregory, D. (1999). Introduction. In J. Duncan \& D. Gregory (Eds.), Writes of passage: Reading travel writing (pp. 1-13). London: Routledge.

Eckart, W. U., Hübner, K., \& Nawa, C. (2012). The rise of the natural sciences-Bunsen, Kirchhoff, and Helmholtz. In P. Meusburger \& T. Schuch (Eds.), Wissenschaftsatlas of Heidelberg University: Spatio-temporal relations of academic knowledge production (pp. 96-99). Knittlingen: Bibliotheca Palatina.

Effinger, M., \& Zimmermann, K. (2012). From the safes of Germany's oldest university library. In P. Meusburger \& T. Schuch (Eds.), Wissenschaftsatlas of Heidelberg University: Spatiotemporal relations of academic knowledge production (pp. 202-203). Knittlingen: Bibliotheca Palatina.

Ehrenpreis, S. (2015). Beobachtungen zur Rolle des Heidelberger Katechismus im frühneuzeitlichen Erziehungs- und Schulwesen [Observations about the role of the Heidelberg Catechism in the early modern educational system]. In C. Strohm \& J. Stievermann (Eds.), Profil und Wirkung des Heidelberger Katechismus: Neue Forschungsbeiträge anläßlich des 450jährigen Jubiläums. The Heidelberg Catechism: Origins, characteristics, and influences: Essays in reappraisal in commemoration of its 450th anniversary (pp. 308-319). Schriften des Vereins für Reformationsgeschichte: Vol. 215. Gütersloh: Gütersloher Verlagshaus.

Einstein, A. (1911). Bemerkungen zu dem Gesetz von Eötvös [Comments on Eötvös's law]. Annalen der Physik, 339, 165-169. doi:https://doi.org/10.1002/andp.19113390109

Engehausen, F. (2012). Heidelberg University in the Vormärz and in the 1848/49 revolution. In P. Meusburger \& T. Schuch (Eds.), Wissenschaftsatlas of Heidelberg University: Spatiotemporal relations of academic knowledge production (pp. 90-91). Knittlingen: Bibliotheca Palatina.

Eötvös, L. (1886). Über den Zusammenhang der Oberflächenspannung der Flüssigkeiten mit ihrem Molecularvolumen [On the relationship between the surface tension of liquids and molecular volume]. Annalen der Physik, 263, 448-459. doi:https://doi.org/10.1002/andp.18862630309

Eredics, P. (2008). Ungarische Studenten und ihre Übersetzungen aus dem Niederländischen ins Ungarische in der Frühen Neuzeit [Hungarian students and their translations from Dutch to Hungarian in the early modern age]. Debrecener Studien zur Literatur: Vol. 14. Frankfurt am Main: Lang.

Eulenburg, F. (1904). Die Frequenz der deutschen Universitäten von ihrer Gründung bis zur Gegenwart [The number of students at German universities from their founding to the present]. Abhandlungen der königlich sächsischen Gesellschaft der Wissenschaften zu Leipzig: Vol. 24, No. 2. Leipzig: Teubner.

Fassel, H. (2006). Hugo Meltzl von Lomnitz (1846-1908): Der erste Ordinarius für Germanistik in Klausenburg und seine Beziehungen zu den Universitäten in Heidelberg und Leipzig [Hugo Meltzl von Lomnitz (1846-1908): The first full professor of German studies at Klausenburg and his relations to the universities of Heidelberg and Leipzig]. In M. Fata, G. Kurucz, \& A. Schindling (Eds.), Peregrinatio Hungarica: Studenten aus Ungarn an deutschen und österreichischen Hochschulen vom 16. bis zum 20. Jahrhundert (pp. 437-457). ContuberniumTübinger Beiträge zur Universitäts- und Wissenschaftsgeschichte: Vol. 64. Stuttgart: Steiner.

Fata, M. (2000). Ungarn, das Reich der Stephanskrone, im Zeitalter der Reformation und Konfessionalisierung: Multiethnizität, Land und Konfession 1500-1700 [Hungary, the lands of Saint Stephen's Crown, in the age of the Reformation and confessionalization: Multiethnicity, country, and confession, 1500-1700]. Katholisches Leben und Kirchenreform im Zeitalter der Glaubensspaltung: Vol. 60. Münster: Aschendorff.

Fata, M. (2004). Deutsche und schweizerische Einflüsse auf die Reformation in Ungarn im 16. Jahrhundert: Aspekte der frühneuzeitlich-vormodernen Identität zwischen Ethnie und Konfession [German and Swiss influences on the Reformation in Hungary in the sixteenth century: Aspects of pre- and early-modern identity between ethnicity and religious denomination]. In W. Kühlmann \& A. Schindling (Eds.), Deutschland und Ungarn in ihren Bildungs- und 
Wissenschaftsbeziehungen während der Renaissance (pp. 53-91). Contubernium-Tübinger Beiträge zur Universitäts- und Wissenschaftsgeschichte: Vol. 62. Stuttgart: Steiner.

Fata, M. (2006). Studenten aus Ungarn und Siebenbürgen an der Universität Tübingen: Eine 500 Jahre lange Beziehungs- und Wirkungsgeschichte [Students from Hungary and Transylvania at the University of Tübingen: A 500-year history of relations and impacts]. In M. Fata, G. Kurucz \& A. Schindling (Eds.), Peregrinatio Hungarica: Studenten aus Ungarn an deutschen und österreichischen Hochschulen vom 16. bis zum 20. Jahrhundert (pp. 229-264). ContuberniumTübinger Beiträge zur Universitäts- und Wissenschaftsgeschichte: Vol. 64. Stuttgart: Steiner.

Fata, M. (2014). Migration im kameralistischen Staat Joseph II: Theorie und Praxis der Ansiedlungspolitik in Ungarn, Siebenbürgen, Galizien und der Bukowina von 1768 bis 1790 [Migration in the cameralistic state of Joseph II: Theory and practice of settlement policies in Hungary, Transylvania, Galicia, and Bukowina from 1768 to 1790]. Münster: Aschendorff.

Fata, M., \& Millisits, M. (2010). Calvin in der ungarischen Erinnerungskultur [Calvin in the Hungarian memory culture]. In M. Fata \& A. Schindling (Eds.), Calvin und Reformiertentum in Ungarn und Siebenbürgen: Helvetisches Bekenntnis, Ethnie und Politik vom 16. Jahrhundert bis 1918 (pp. 533-564). Reformationsgeschichtliche Studien und Texte: Vol. 155. Münster: Aschendorff.

Fata, M., \& Schindling, A. (2006). Peregrinatio Hungarica: Studenten aus Ungarn an deutschen und österreichischen Hochschulen vom 16. bis zum 20. Jahrhundert [Peregrinatio Hungarica: Students from Hungary at German and Austrian universities from the sixteenth to the twentieth century]. In M. Fata, G. Kurucz, \& A. Schindling (Eds.), Peregrinatio Hungarica: Studenten aus Ungarn an deutschen und österreichischen Hochschulen vom 16. bis zum 20. Jahrhundert (pp. 3-35). Contubernium-Tübinger Beiträge zur Universitäts- und Wissenschaftsgeschichte: Vol. 64. Stuttgart: Steiner.

Fata, M., \& Schindling, H. (2010). Vorbemerkung [Preliminary note]. In M. Fata \& A. Schindling (Eds.), Calvin und Reformiertentum in Ungarn und Siebenbürgen: Helvetisches Bekenntnis, Ethnie und Politik vom 16. Jahrhundert bis 1918 (pp. v-xvi). Reformationsgeschichtliche Studien und Texte: Vol. 155. Münster: Aschendorff.

Frank, G., \& Treu, M. (Eds.). (2001). Melanchthon und Europa: Bd. 1. Skandinavien und Mittelosteuropa. Melanchthon-Schriften der Stadt Bretten: Vol. 6, Pt. 1. Stuttgart: Thorbecke.

Frank, T. (1999). Station Berlin: Ungarische Wissenschaftler und Künstler in Deutschland 19191933 [Berlin: Hungarian scholars and artists in Germany, 1919-1933]. IMIS-Beiträge, 10, 7-38.

Frank, T. (2012). Acts of creation: The Eötvös family and the rise of science education in Hungary. In M. G. Ash \& J. Surman (Eds.), The nationalization of scientific knowledge in the Habsburg Empire, 1848-1918 (pp. 118-137). Houndmills: Palgrave Macmillan.

Freller, T. (2007). Adlige auf Tour: Die Erfindung der Bildungsreise [Noblemen on tour: The invention of the educational journey]. Ostfildern: Jan Thorbecke.

Fricke, K., Koch, A., Meusburger, P., \& Preusker, C. (2012). The student body 1803 to 1945. In P. Meusburger \& T. Schuch (Eds.), Wissenschaftsatlas of Heidelberg University: Spatiotemporal relations of academic knowledge production (pp. 82-85). Knittlingen: Bibliotheca Palatina.

Gantner, B. E. (2006). Jüdische Studenten aus dem Königreich Ungarn an der Friedrich-WilhelmsUniversität in Berlin um die Wende von 19. zum 20. Jahrhundert [Jewish students from the Kingdom of Hungary at the Friedrich-Wilhelms-University in Berlin at the turn from the nineteenth to the twentieth century]. In M. Fata, G. Kurucz, \& A. Schindling (Eds.), Peregrinatio Hungarica: Studenten aus Ungarn an deutschen und österreichischen Hochschulen vom 16. bis zum 20. Jahrhundert (pp. 459-469). Contubernium-Tübinger Beiträge zur Universitäts- und Wissenschaftsgeschichte: Vol. 64. Stuttgart: Steiner.

Garms-Cornides, E. (2005). Hofmeister auf Grand Tour [Court tutors on Grand Tour]. In R. Babel \& W. Paravicini (Eds.), Grand Tour: Adeliges Reisen und europäische Kultur vom 14. bis zum 18. Jahrhundert. Akten der internationalen Kolloquien in der Villa Vigoni 1999 und im Deutschen Historischen Institut in Paris 2000 (pp. 255-274). Beihefte der Francia: Vol. 60. Ostfildern: Jan Thorbecke.

Gebhardt, A. (2008). Philipp Melanchthon: Praeceptor Germaniae [Philipp Melanchthon: The teacher of Germany]. Marburg: Tectum. 
Giebermann, G. (2005). Albert Molnár (1574-1634), ungarischer reformierter Theologe und Wandergelehrter, 1615-1619 Kantor und Rektor in Oppenheim [Albert Molnár (1574-1634), a Hungarian Reformed theologian and wandering scholar, 1615-1629 cantor and rector in Oppenheim]. Oppenheimer Hefte, 30-31, 2-100.

Glatz, F. (Ed.). (1995). Magyarország története térképeken elbeszélve 1: Virágkor és pusztulás. A kezdetektól 1606-ig [The history of Hungary told in maps 1: Heyday and decay. From the beginning until 1606]. Budapest: MTA Történettudományi Intézete, História.

Gömöri, G. (1985). Hungarian students and visitors in 16th-17th century England. Hungarian Studies, 1, 31-50.

Gönczi, K. (2006). Juristischer Wissenstransfer von der Göttinger Universität in das Königreich Ungarn im späten 18. Jahrhundert [Knowledge transfer in the field of law from Göttingen University to the Kindom of Hungary in the late eighteenth century]. In M. Fata, G. Kurucz, \& A. Schindling (Eds.), Peregrinatio Hungarica: Studenten aus Ungarn an deutschen und österreichischen Hochschulen vom 16. bis zum 20. Jahrhundert (pp. 175-196). ContuberniumTübinger Beiträge zur Universitäts- und Wissenschaftsgeschichte: Vol. 64. Stuttgart: Steiner.

Gräfe, K.-H. (2004). Von der Asternrevolution zur Räterepublik: Ungarn 1918/19 [From the Aster Revolution to the Soviet Republic: Hungary 1918-1919]. UTOPIE kreativ, 168, 885-900. Retrieved from http://www.rosalux.de/fileadmin/rls_uploads/pdfs/168_graefe.pdf

Gregory, D. (1999). Scripting Egypt: Orientalism and the cultures of travel. In J. Duncan \& D. Gregory (Eds.), Writes of passage: Reading travel writing (pp. 114-150). London: Routledge.

Gregory, D. (2000). Cultures of travel and spatial formations of knowledge. Erdkunde, 54, 297319. Retrieved from http://www.jstor.org/stable/25647315

Greschat, M. (2010). Philipp Melanchthon: Theologe, Pädagoge und Humanist [Philipp Melanchthon: Theologian, educator, and humanist]. Gütersloh: Gütersloher Verlagshaus.

Gunst, P. (1989). Agrarian systems of central and eastern Europe. In D. Chirot (Ed.), The origins of backwardness in eastern Europe: Economics and politics from the Middle Ages to the early twentieth century (pp. 53-91). Berkeley: University of California Press.

Győri, J. L. (2010). Zur Bedeutung des Reformierten Kollegiums Debrecen für Kultur und Politik Ungarns vom 16. bis zum 19. Jahrhundert [The importance of the Reformed College in Debrecen for the culture and politics of Hungary from the sixteenth to the nineteenth century]. In M. Fata \& A. Schindling (Eds.), Calvin und Reformiertentum in Ungarn und Siebenbürgen. Helvetisches Bekenntnis, Ethnie und Politik vom 16. Jahrhundert bis 1918 (pp. 239-259). Reformationsgeschichtliche Studien und Texte: Vol. 155. Münster: Aschendorff.

Hammerstein, N. (1995). Aufklärung und Universitäten in Europa: Divergenzen und Probleme [Enlightenment and universities in Europe: Divergencies and problems]. In N. Hammerstein (Ed.), Universitäten und Aufklärung (pp. 191-205). Göttingen: Wallstein.

Hammerstein, N. (1996). Epilogue: The enlightenment. In H. de Ridder-Symoens (Ed.), Universities in early modern Europe (1500-1800) (pp. 621-640). A history of the university in Europe: Vol. 2. Cambridge, UK: Cambridge University Press

Hebeisen, C., \& Schmid, T. (2003). De Zusato, Coloniensis dioecesis: Über Herkunftsräume armer Universitätsbesucher im Alten Reich (1375 bis 1550) [De Zusato, Coloniensis dioecesis: Regional origins of poor students in the Old Empire (1375-1550)]. In R. C. Schwinges (Ed.), Universität im Mittelalter (pp. 28-50). Jahrbuch für Universitätsgeschichte: Vol. 6. Stuttgart: Steiner.

Heiss, G. (2005). Bildungs- und Reiseziele österreichischer Adeliger in der Frühen Neuzeit [Educational goals and destinations of Austrian noblemen in Early Modern Age]. In R. Babel \& W. Paravicini (Eds.), Grand Tour: Adeliges Reisen und europäische Kultur vom 14. bis zum 18. Jahrhundert. Akten der internationalen Kolloquien in der Villa Vigoni 1999 und im Deutschen Historischen Institut in Paris 2000 (pp. 217-235). Beihefte der Francia: Vol. 60. Ostfildern: Jan Thorbecke.

Heitmann, K. (1975). Sextil Puşcariu, Deutschland und die deutsche Wissenschaft [Sextil Puşcariu, Germany, and German science]. In P. Philippi (Ed.), Siebenbürgen als Beispiel europäischen Kulturaustausches (pp. 117-142). Siebenbürgisches Archiv: Vol. 12. Cologne: Böhlau. 
Heller, A. (1882-1884). Geschichte der Physik von Aristoteles bis auf die neueste Zeit [History of physics from Aristotle to today]. 2 vols. Stuttgart: Enke.

Heltai, J. (1982). Adattár a heidelbergi egyetemen 1595-1621 között tanult magyarországi diákokról és pártfogóikról [Inventory of the Hungarian students of Heidelberg University and their patrons, 1595-1621]. Az Országos Széchényi Könyvtár évkönyve, 1980, 243-347.

Heltai, J. (1994). Alvinczi Péter és a heidelbergi peregrinusok [Péter Alvinczi and the peregrines of Heidelberg]. Budapest: Balassi Kiadó.

Heltai, J. (1999). Die Heidelberger Peregrination 1525-1621 [The Heidelberg peregrination, 15251621]. In A. Szabó (Ed.), Iter Germanicum: Deutschland und die Reformierte Kirche in Ungarn im 16.-17. Jahrhundert (pp. 169-179). Budapest: Calvin.

Heltai, J. (2006). Die Heidelberger Peregrination calvinistischer Studenten aus Ungarn und Siebenbürgen 1597-1621: Ihr Verlauf im Spiegel der Zahlen und ihre Auswirkung [The Heidelberg peregrination of Calvinist students from Hungary and Transylvania, 1597-1621: Its course as reflected by numbers and effects]. In M. Fata, G. Kurucz, \& A. Schindling (Eds.), Peregrinatio Hungarica: Studenten aus Ungarn an deutschen und österreichischen Hochschulen vom 16. bis zum 20. Jahrhundert (pp. 65-80). Contubernium-Tübinger Beiträge zur Universitäts- und Wissenschaftsgeschichte: Vol. 64. Stuttgart: Steiner.

Henss, W. (1983). Der Heidelberger Katechismus im konfessionspolitischen Kräftespiel seiner Frühzeit: Historisch-bibliographische Einführung [The Heidelberg Catechism in the confessional power play of its early period: A bibliographical introduction to its history]. Zurich: Theologischer Verlag.

Höchsmann, J. (1894-1895). Zur Geschichte der Gegenreformation in Ungarn und Siebenbürgen, Teil 1 [On the history of the Counter-Reformation in Hungary and Transylvania, Part 1]. Archiv des Vereins für Siebenbürgische Landeskunde, 26 (Neue Folge), 522-572.

Höchsmann, J. (1896-1897). Zur Geschichte der Gegenreformation in Ungarn und Siebenbürgen, Teil 2 [On the history of the Counter-Reformation in Hungary and Transylvania, part 2]. Archiv des Vereins für Siebenbürgische Landeskunde, 27 (Neue Folge), 162-260.

Honeck, M., \& Meusburger, P. (2012). American students up to 1914. In P. Meusburger \& T. Schuch (Eds.), Wissenschaftsatlas of Heidelberg University: Spatio-temporal relations of academic knowledge production (pp. 296-299). Knittlingen: Bibliotheca Palatina.

Horn, I. (2014). Changing attitudes towards study tours among the Transylvanian elite. In G. Almási (Ed.), Study tours and intellectual-religious relationships (pp. 35-53). A divided Hungary in Europe: Exchanges, networks and representations, 1541-1699: Vol. 1. Cambridge, UK: Cambridge Scholar Publishing.

Hotson, H. (1995). Irenicism and dogmatics in the confessional age: Pareus and Comenius in Heidelberg, 1614. Journal of Ecclesiastical History, 46, 432-456. doi:https://doi.org/10.1017/ S0022046900017747

Hotson, H. (2004). Irenicism in the confessional age: The Holy Roman Empire, 1563-1648. In H. Louthan \& R. Zachman (Eds.), Conciliation and confession: Struggling for unity in the age of reform, 1415-1648 (pp. 228-285). Notre Dame: University of Notre Dame Press.

Hotson, H (2008). Central Europe, 1550-1700. In D. Whitford (Ed.), Reformation and early modern Europe: A guide to research III (pp. 161-206). Kirksville: Truman State University Press.

Hoyler, M., \& Taylor, P. J. (2012). European centres for the natural sciences, 1500 to 1900 . In P. Meusburger \& T. Schuch (Eds.), Wissenschaftsatlas of Heidelberg University: Spatiotemporal relations of academic knowledge production (pp. 76-77). Knittlingen: Bibliotheca Palatina.

Hübner, K. (2010). Gustav Robert Kirchhoff: Das gewöhnliche Leben eines außergewöhnlichen Mannes [Gustav Robert Kirchhoff: The ordinary life of an extraordinary man]. Schriften/Archiv und Museum der Universität Heidelberg: Vol. 16. Heidelberg: Verlag Regionalkultur.

Huttmann, A. (1975). Aspekte des Kulturaustausches in der siebenbürgischen Geschichte der Medizin und der Naturwissenschaften [Aspects of cultural exchange in the Transylvanian history of medicine and the natural sciences]. In P. Philippi (Ed.), Siebenbürgen als Beispiel europäischen Kulturaustausches (pp. 91-106). Siebenbürgisches Archiv: Vol. 12. Cologne: Böhlau. 
Irrgang, S. (2003). Scholar vagus, goliardus, ioculator: Zur Rezeption des, fahrenden Scholaren' im Mittelalter [Wandering scholar, buffoon, prankster: The reception of the wandering scholar in the Middle Ages]. In R. C. Schwinges (Ed.), Universität im Mittelalter (pp. 51-68). Jahrbuch für Universitätsgeschichte: Vol. 6. Stuttgart: Steiner.

Jancsó, T. (2013). A magyar felsőoktatás területi szerkezetének és hallgatói létszámának alakulása 1900-tól 1945-ig [Changes in the spatial structure and number of students in Hungarian higher education between 1900 and 1945]. In Z. Bottlik (Ed.), Önálló lépések a tudomány területén (pp. 29-46). Budapest: Department of History, Eötvös Loránd University.

Jesse, H. (2005). Leben und Wirken des Philipp Melanchthon: Dr. Martin Luthers theologischer Weggefährte [Life and work of Philipp Melanchthon: Dr. Martin Luther's theological companion]. Munich: Herbert Utz.

Jöns, H., Heffernan, M., \& Meusburger, P. (2017). Mobilities of knowledge: An introduction. In H. Jöns, P. Meusburger, \& M. Heffernan (Eds.), Mobilities of knowledge (pp. 1-19). Knowledge and Space: Vol. 10. Cham: Springer. doi:https://doi.org/10.1007/978-3-319-44654-7

Juhász, T. (2010). Mirabilis est cursus verbi Dei! Die Entwicklung des Helvetischen Bekenntnisses in Ungarn und Siebenbürgen [The course of God's words is miraculous! The development of the Helvetic religious denomination in Hungary and Transylvania]. In M. Fata \& A. Schindling (Eds.), Calvin und Reformiertentum in Ungarn und Siebenbürgen: Helvetisches Bekenntnis, Ethnie und Politik vom 16. Jahrhundert bis 1918 (pp. 63-78). Reformationsgeschichtliche Studien und Texte: Vol. 155. Münster: Aschendorff.

Kadarkay, A. (1991). Georg Lukács: Life, thought, and politics. Cambridge, MA: Blackwell.

Kaesler, D. (1990). Mannheim, Karl. In Neue Deutsche Biographie: Vol. 16: Maly-Melanchthon (pp. 67-69). Berlin: Duncker \& Humblot. Retrieved from http://www.deutsche-biographie.de/ pnd118577190.html

Karadi, E. (1986). Der „Sonntagskreis” und die Weimarer Kultur [The "Sunday Circle” and culture in the Weimar period]. In H. Gaßner (Ed.), Wechselwirkungen: Ungarische Avantgarde in der Weimarer Republik (pp. 526-540). Marburg: Jonas.

Karadi, E. (2003). Karl Mannheim zwischen Kultursoziologie und Wissenssoziologie [Karl Mannheim between the sociology of culture and the sociology of knowledge]. In E. Demm \& N. Chamba (Eds.), Soziologie, Politik und Kultur. Von Alfred Weber zur Frankfurter Schule (pp. 121-140). Frankfurt am Main: P. Lang.

Karadi, E., \& Vezér, E. (Eds.). (1985). Georg Lukács, Karl Mannheim und der Sonntagskreis [George Lukács, Karl Mannheim, and the Sunday Circle]. Frankfurt am Main: Sendler.

Karády, V. (1997). Felekezeti egyenlõtlenségek és iskolarendszer: Történeti-szociológiai tanulmányok [Confessional inequalities and the school system: Studies in historical sociology]. Budapest: Replika-könyvek.

Karády, V. (2004). Der "gescheite Jude" in Ungarn vor 1919: Bildungsinvestitionen und kulturelle Assimilation [The "smart Jew" in pre-1919 Hungary: Educational investments and cultural assimilation]. In A. Kerekes, A. Millner, P. Plener, \& B. Rásky (Eds.), Leitha und Lethe. Symbolische Räume und Zeiten in der Kultur Österreich-Ungarns (pp. 231-240). KulturHerrschaft-Differenz: Vol. 6. Tübingen: Francke.

Karády, V. (2012). Az értelmiség kialakulásának kezdetei a 19. századi Magyarországon. [The emergence of professional intellectuals in nineteenth century Hungary]. In V. Karády \& P. T. Nagy (Eds.), Iskolázás. értelmiség és tudomány a 19.-20. századi Magyarországon (pp. 13-31). Budapest: Wesley János Lelkészképző Fóiskola.

Karády, V. (2013). Zsidóság és modernitás [Judaism and modernity]. Rubicon, 4, 62-77.

Karády, V., \& Nagy, P. T. (Eds.). (2012). Iskolázás, értelmiség és tudomány a 19.-20. századi Magyarországon [Education, intelligentsia, and science in nineteenth- and twentieth-century Hungary]. Budapest: Wesley János Lelkészképző Fôiskola.

Kardos, J. (Ed.). (2000). A magyar felsốoktatás évszázadai [Centuries of Hungary’s higher education]. Budapest: Nemzeti Tankönyvkiadó.

Kármán, G. (2006). Identitás és határok: 17. századi utazók [Identity and borders: Travelers in the seventeenth century]. Korall, 26, 73-95. 
Kármán, G. (2013). Gábor Bethlen's diplomats at the Protestant courts of Europe. Hungarian Historical Review, 2, 790-823.

Keserú, B. (Ed.). (1989). Teleki Pál külföldi tanulmányútja: Levelek, számadások, iratok 16951700 [The study tour of Pál Teleki: Letters, accounts, documents, 1695-1700]. Fontes rerum scolasticarum III. Szeged: Szegedi Oktatástörténeti Munkaközösség

Kettler, D., Meja, V., \& Stehr, N. (1989). Politisches Wissen: Studien zu Karl Mannheim [Political knowledge: Studies about Karl Mannheim]. Frankfurt am Main: Suhrkamp.

Kintzinger, M. (2012). Universität [University]. In P. den Boer, H. Duchhardt, G. Kreis, \& W. Schmale (Eds.), Europäische Erinnerungsorte 2: Das Haus Europa (pp. 307-312). Munich: Oldenbourg

Kohnle, A. (2001). Die Universität Heidelberg als Zentrum des reformierten Protestantismus im 16. und frühen 17. Jahrhundert [Heidelberg university as a center of Reformed Protestantism in the sixteenth and early seventeenth centuries]. In L. Szögi \& M. Font (Eds.), Die Ungarische Universitätsbildung und Europa (pp. 141-161). Pécs: Universitas Quinqueecclesiensis.

Kohnle, A., \& Wolgast, E. (2012). The Heidelberg Catechism of 1563: Origin and distribution. In P. Meusburger \& T. Schuch (Eds.), Wissenschaftsatlas of Heidelberg University: Spatiotemporal relations of academic knowledge production (pp. 58-59). Knittlingen: Bibliotheca Palatina.

König, G. (1903). Einleitung in die allgemeine Theorie der algebraischen Größen [Introduction to the general theory of algebraic magnitudes]. Leipzig: Teubner.

Köpeczi, B. (Ed.). (1990). Kurze Geschichte Siebenbürgens [A brief history of Transylvania]. Budapest: Akadémiai Kiadó. Retrieved from http://www.mek.oszk.hu/02100/02113/html

Köpf, U. (2010a). Melanchthon und die Reform der Universität Tübingen [Melanchthon and the reform of the University of Tübingen]. In S. Lorenz, R. Rieger, E. Seidl, \& K. Wiegmann (Eds.), Vom Schüler der Burse zum "Lehrer Deutschlands": Philipp Melanchthon in Tübingen (pp. 187-195). Tübinger Kataloge: Vol. 88. Tübingen: Universitätsstadt Tübingen, Fachbereich Kultur, Stadtmuseum

Köpf, U. (2010b). Philipp Melanchthon: Leben und Werk [Philipp Melanchthon: Life and work]. In S. Lorenz, R. Rieger, E. Seidl, \& K. Wiegmann (Eds.), Vom Schüler der Burse zum "Lehrer Deutschlands": Philipp Melanchthon in Tübingen (pp. 13-49). Tübinger Kataloge: Vol. 88. Tübingen: Universitätsstadt Tübingen, Fachbereich Kultur, Stadtmuseum.

Köpf, U. (2010c). Der Reformer Philipp Melanchthon [Philipp Melanchthon the reformer]. In F. Schweitzer, S. Lorenz, \& E. Seidl (Eds.), Philipp Melanchthon: Seine Bedeutung für Kirche und Theologie, Bildung und Wissenschaft (pp. 11-26). Theologie Interdisziplinär: Vol. 8. Neukirchen-Vluyn: Neukirchener Verlagsgesellschaft.

Kovács, A. (1922). A zsidóság térfoglalása Magyarországon [The Jewish expansion in Hungary]. Budapest: Author's edition. Retrieved from http://www.angelfire.com/zine2/judeolog/cikkek/ zst1.htm

Központi Statisztikai Hivatal (KSH, Central Statistical Office of Hungary). (1920). A Magyar Szent Korona Országainak 1910: Évi népszámlálása VI. Végeredmények összefoglalása [Census of the states of the Holy Crown of Hungary, 1910: Vol. VI. Summary of final results]. Budapest: Athenaeum. Retrieved from https://library.hungaricana.hu/hu/view/NEDA_1910_06/?pg=0\& layout $=\mathrm{s}$

Kühlmann, W., Hartmann, V., \& El Kholi, S. (2012). The golden age of late Humanism (ca. 1560 to 1622). In P. Meusburger \& T. Schuch (Eds.), Wissenschaftsatlas of Heidelberg University: Spatio-temporal relations of academic knowledge production (pp. 60-61). Knittlingen: Bibliotheca Palatina.

Kühnel, H. (1964). Die adelige Cavaliers-Tour im 17. Jahrhundert [The nobleman's Grand Tour in the seventeenth century]. Jahrbuch für Landeskunde Niederösterreichs, 36 (Neue Folge), 364-384.

Kuzias, T. (2007). Georg Lukács und der Goethepreis: Zum folgenreichen Verhältnis von Nietzsche und Marx beim jungen Lukács [George Lukács and the Goethe award: On the portentous relationship between Nietzsche and Marx for the young Lukács]. Beiträge zur Geschichte der Arbeiterbewegung, 49, 111-134. 
Ladányi, S. (1997). Peregrination ungarischer reformierter Studenten an westeuropäische Universitäten im 16.-17. Jahrhundert: Westeuropäische Einflüsse in der ungarischen Reformierten Kirche, mit besonderem Hinblick auf Holland [Peregrination of Hungarian Reformed students to western European universities in the sixteenth and seventeenth centuries: Western European influences in the Hungarian Reformed church with special view on Holland]. In L. Szögi \& J. Varga (Eds.), Universitas Budensis, 1395-1995: International conference for the history of universities on the occasion of the 600th anniversary of the foundation of the University of Buda (pp. 199-209). Budapest: ELTE, Library and Archive.

Ladányi, S. (1999). Ungarische Studenten in Frankfurt an der Oder [Hungarian students in Frankfurt at the Oder]. In A. Szabó (Ed.), Iter Germanicum: Deutschland und die Reformierte Kirche in Ungarn im 16.-17. Jahrhundert (pp. 215-220). Budapest: Calvin.

Ladányi, S. (2001). Bedeutung und Wirkung der protestantischen Kollegs und des Auslandsstudiums im Ungarn des 16. bis 18. Jahrhunderts [Importance and impact of Protestant colleges and of studies abroad in Hungary of the sixteenth to eighteenth centuries]. In L. Szögi \& M. Font (Eds.), Die Ungarische Universitätsbildung und Europa (pp. 133-139). Pécs: Universitas Quinqueecclesiensis.

Leibetseder, M. (2004). Die Kavalierstour: Adlige Erziehungsreisen im 17. und 18. Jahrhundert [The Grand Tour: Noblemen's educational travel in the seventeenth and eighteenth centuries]. Cologne: Böhlau.

Leibetseder, M. (2013). Educational journey, Grand Tour. European History Online (EGO). Mainz: Leibniz Institute of European History (IEG). Retrieved from http://www.ieg-ego.eu/ leibetsederm-2013-en

Leppin, V., \& Wien, U. A. (Eds.). (2005). Konfessionsbildung und Konfessionsstruktur in Siebenbürgen in der frühen Neuzeit [Denominational education and denominational structure in Transylvania in the Early Modern Age]. Wiesbaden: Steiner.

Lepsius, R. M. (2012). Intellectual circles at the beginning of the 20th century. In P. Meusburger \& T. Schuch (Eds.), Wissenschaftsatlas of Heidelberg University: Spatio-temporal relations of academic knowledge production (pp. 112-113). Knittlingen: Bibliotheca Palatina.

Loewy, H. (1999). Medium und Initiation: Béla Balázs. Märchen, Ästhetik, Kino [Medium and initiation: Béla Balázs. Fairy tales, aesthetics, cinema] (Doctoral thesis, Konstanz University, Germany). Retrieved from https://kops.unikonstanz de/bitstream/handle/123456789/3615/ 400_1.pdf; sequence= 1

Lorenz, S. (2010). Melanchthon in Tübingen (1512-1518). In S. Lorenz, R. Rieger, E. Seidl, \& K. Wiegmann (Eds.), Vom Schüler der Burse zum ,Lehrer Deutschlands “: Philipp Melanchthon in Tübingen (pp. 83-103). Tübinger Kataloge: Vol. 88. Tübingen: Universitätsstadt Tübingen, Fachbereich Kultur, Stadtmuseum.

Ludwig, U. (2009). Philippismus und orthodoxes Luthertum an der Universität Wittenberg [Philippism and orthodox Lutherism at the University of Wittenberg]. Reformatische Studien und Texte: Vol. 153. Münster: Aschendorff.

Lukács, G. (1911). Die Seele und die Formen [Soul \& form]. Berlin: Egon Fleischel.

Lukács, G. (1920). Die Theorie des Romans: Ein geschichtsphilosophischer Versuch über die Formen der großen Epik [The theory of the novel: A historico-philosophical essay on the forms of great epic literature]. Berlin: Cassirer.

Lukács, G. (2010). Soul \& form (J. T. Sanders \& K. Terezakis, Eds.; A. Bostock, Trans.; with an introduction by J. Butler). New York: Columbia University Press. (Original work published 1911).

Maleczek, W. (1995). Deutsche Studenten an Universitäten in Italien [German students at universities in Italy]. In S. de Rachewiltz \& J. Riedmann (Eds.), Kommunikation und Mobilität im Mittelalter: Begegnungen zwischen dem Süden und der Mitte Europas (11.-14. Jahrhundert) (pp. 77-96). Sigmaringen: Thorbecke.

Markó, L. (Ed.). (2001-2007). Új Magyar életrajzi lexikon [New Hungarian biographical lexicon] (Vols. 1-6). Budapest: Magyar Könyvklub-Helikon. 
Marshall, R. K. (2003). Elizabeth Stuart—die Winterkönigin [Elizabeth Stuart—The winter queen]. In P. Wolf, M. Henker, E. Brockhoff, B. Steinherr, \& S. Lippold (Eds.), Der Winterkönig Friedrich V: Der letzte Kurfürst aus der Pfalz. Amberg, Heidelberg, Prag, Den Haag (pp. 34-45). Veröffentlichungen zur Bayerischen Geschichte und Kultur: 46/03. Augsburg: Haus der Bayerischen Geschichte.

Matrikelbuch der Universität Heidelberg: Sommer-Semester 1871 bis Sommer-Semester 1872 [Heidelberg University registry, summer semester 1871 through summer semester 1872]. Retrieved from http://digi.ub.uni-heidelberg.de/diglit/matrikel1871

Matrikelbuch der Universität Heidelberg: Winter-Semester 1872/73 bis Winter-Semester 1894/95 [Heidelberg University registry, winter semester 1872-1873 through winter semester 1894-1895]. Retrieved from http://digi.ub.uni-heidelberg.de/diglit/matrikel1872

Matrikelbuch der Universität Heidelberg: Sommer-Semester 1895 bis Sommer-Semester 1906 [Heidelberg University registry: Summer semester 1895 through summer semester 1906]. Retrieved from http://digi.ub.uni-heidelberg.de/matrikel1895

Matrikelbuch der Universität Heidelberg: Winter-Semester 1906/1907 bis Sommer-Semester 1916 [Heidelberg University registry: Winter semester 1906-1907 to summer semester 1916]. Retrieved from http://digi.ub.uni-heidelberg.de/matrikel1907

Matrikelbuch der Universität Heidelberg: Kriegs-Wintersemester 1916/1917 bis Sommer-Semester 1920 [Heidelberg University registry: War-winter semester 1916-1917 to summer semester 1920]. Retrieved from http://digi.ub.uni-heidelberg.de/matrikel1916

Merkel, G. (2012). University property and income up to the end of the 17th century. In P. Meusburger \& T. Schuch (Eds.), Wissenschaftsatlas of Heidelberg University: Spatiotemporal relations of academic knowledge production (pp. 46-47). Knittlingen: Bibliotheca Palatina.

Meusburger, P. (2003). Entwicklung der wissenschaftlichen Zusammenarbeit zwischen den Geographischen Instituten der Eötvös Loránd Universität in Budapest und der Universität Heidelberg: Einige persönlichen Anmerkungen [Thedevelopment of scientific cooperation between the Departments of Geography of Eötvös Loránd University and Heidelberg University: Some personal comments]. In J. Nemes Nagy (Ed.), Frontiers of geography: The 20th anniversary of the partnership between Eötvös Loránd Tudományegyetem Budapest and Ruprecht Karls Universität Heidelberg (pp. 19-31). Budapest: Department of Regional Geography, Eötvös Loránd University.

Meusburger, P. (2010). Ungarische Studenten an der Universität Heidelberg: Einflussfaktoren und Wechselwirkungen der Bildungswanderung im Laufe der Jahrhunderte [Hungarian students at Heidelberg University: Factors and interactions influencing educational migrations over the centuries]. Budapest: Eötvös Kiadó.

Meusburger, P. (2012). Heidelberg: Relations between a town and its university. In P. Meusburger $\&$ T. Schuch (Eds.), Wissenschaftsatlas of Heidelberg University: Spatio-temporal relations of academic knowledge production (pp. 18-35). Knittlingen: Bibliotheca Palatina.

Meusburger, P. (2013). Relations between knowledge and economic development: Some methodological considerations. In P. Meusburger, J. Glückler, \& M. El Meskioui (Eds.), Knowledge and the economy (pp. 15-42). Knowledge and Space: Vol. 5. Dordrecht: Springer. doi:https:// doi.org/10.1007/978-94-007-6131-5_2

Meusburger, P., \& Probáld, F. (2010). Magyar diákok a Heidelbergi Egyetemen: A kulturális kölcsönhatás történeti és földrajzi tényezöi [Hungarian students at Heidelberg University: Historical and geographical factors of cultural interaction]. Földrajzi Közlemények, 134, 59-73.

Meusburger, P., \& Probáld, F. (2012). Hungarian students at Heidelberg University up to 1919. In P. Meusburger \& T. Schuch (Eds.), Wissenschaftsatlas of Heidelberg University: Spatiotemporal relations of academic knowledge production (pp. 304-305). Knittlingen: Bibliotheca Palatina.

Meusburger, P., \& Schuch, T. (2010). From mediocrity and existential crisis to scientific excellence: Heidelberg University between 1803 and 1932. In P. Meusburger, D. N. Livingstone, \& H. Jöns (Eds.), Geographies of science (pp. 57-93). Knowledge and Space: Vol. 3. Dordrecht: Springer. doi:https://doi.org/10.1007/978-90-481-8611-2_4 
Meusburger, P., \& Schuch, T. (Eds.). (2012). Wissenschaftsatlas of Heidelberg University: Spatiotemporal relations of academic knowledge production. Knittlingen: Bibliotheca Palatina.

Miethke, J. (1985). Die Studenten [Students]. In P. Moraw (Ed.), Unterwegssein im Spätmittelalter (pp. 49-70). Berlin: Duncker \& Humblot.

Miethke, J. (1995). Die mittelalterliche Universität in der Gesellschaft [The medieval university in society]. In U. Weiß (Ed.), Erfurt: Geschichte und Gegenwart (pp. 169-188). Schriften des Vereins für die Geschichte und Altertumskunde von Erfurt: Vol. 2. Weimar: Hermann Böhlaus Nachfolger.

Miethke, J. (2004). Studieren an mittelalterlichen Universitäten: Chancen und Risiken [Studying at medieval universities: Opportunities and risks]. Education and Society in the Middle Ages and Renaissance: Vol. 19. Leiden: Brill.

Millisits, M. (2012). A Heidelbergi Káté 450 éve [The Heidelberg Catechism: 450 years]. Retrieved from http://www.reformatus.hu/mutat/7512

Módis, L. (1967). Bibliographie der ungarischen Literatur des Heidelberger Katechismus 1563-1963 [Bibliography of the Hungarian literature on the Heidelberg Catechism, 1563-1963]. In T. Bartha (Ed.), Der Heidelberger Katechismus in Ungarn (pp. 331-383). Budapest: Presseabteilung der Synodalkanzlei der reformierten Kirche in Ungarn.

Moraw, P. (1982). Aspekte und Dimensionen älterer deutscher Universitätsgeschichte [Aspects and dimensions of early German university history]. In P. Moraw \& V. Press (Eds.), Academia Gissensis: Beiträge zur älteren Gießener Universitätsgeschichte (pp. 1-43). Veröffentlichungen der Historischen Kommission für Hessen: Vol. 45. Marburg: Elwert.

Moraw, P. (1983). Heidelberg: Universität, Hof und Stadt im ausgehenden Mittelalter [Heidelberg: University, court, and town in the late Middle Ages]. In B. Moeller, H. Patze, \& K. Stackmann (Eds.), Studien zum städtischen Bildungswesen des späten Mittelalters und der frühen Neuzeit (pp. 524-552). Abhandlungen der Akademie der Wissenschaften in Göttingen: Philosophischhistorische Klasse, 3. Folge: Vol. 137. Göttingen: Vandenhoeck \& Ruprecht.

Moraw, P. (1994). Einheit und Vielfalt der Universität im alten Europa [Unity and diversity of the university in old Europe]. In A. Patschovski \& H. Rabe (Eds.), Die Universität in Alteuropa (pp. 11-27). Konstanzer Bibliothek: Vol. 22. Konstanz: Universitätsverlag.

Mühlen, K.-H. zur (1985). Die Heidelberger Disputation Martin Luthers vom 26. April 1518: Programm und Wirkung [The Heidelberg disputation of Martin Luther on April 26, 1518: Program and impact]. In W. Doerr (Ed.), Semper Apertus: 600 Jahre Ruprecht-Karl-Universität Heidelberg 1386-1986 (Vol. 1, pp. 188-212). Berlin: Springer.

Müller, R. A. (1984). Aristokratisierung des Studiums: Bemerkungen zur Adelsfrequenz an süddeutschen Universitäten im 17. Jahrhundert [Feudalization of study at the university: Comments on the percentage of aristocrats in the student body of southern German universities]. Geschichte und Gesellschaft: Zeitschrift für Historische Sozialwissenschaften, 10, 31-46.

Murdock, G. (2000). Calvinism on the frontier, 1600-1660: International Calvinism and the Reformed church in Hungary and Transylvania. Oxford, UK: Clarendon.

Musall, H., \& Scheuerbrandt, A. (1980). Siedlungszerstörungen und Festungswerke im späten 17. und frühen 18. Jahrhundert (1674-1714) [Destruction of settlements and fortifications in the late seventeenth and early eighteenth centuries (1674-1714)]. In Kommission für Geschichtliche Landeskunde in Baden-Württemberg (Ed.), Historischer Atlas von Baden-Württemberg. Beiwort zur Karte VI-12 (pp. 1-21). Stuttgart: Kommission für Geschichtliche Landeskunde in Baden-Württemberg.

Mussgnug, D. (2003). Die Wiederemporbringung der Heidelberger Universität 1803 [The revival of Heidelberg University, 1803]. In A. Kohnle, F. Engehausen, F. Hepp, \& K. L. Fuchs (Eds.), „... so geht hervor ein' neue Zeit“: Die Kurpfalz, im Übergang an Baden 1803“ (pp. 131-145). Heidelberg: Regionalkultur.

Nagy, B. (1967). Geschichte und Ausgaben des Heidelberger Katechismus in Ungarn im 16. und 17. Jahrhundert [History and editions of the Heidelberg Catechism in Hungary in the sixteenth and seventeenth centuries]. In T. Bartha (Ed.), Der Heidelberger Katechismus in Ungarn (pp. 29-82). Budapest: Presseabteilung der Synodalkanzlei der reformierten Kirche in Ungarn.

Naylor, S., \& Ryan, J. R. (Eds.). (2010). New spaces of exploration: Geographies of discovery in the twentieth century. London: I. B. Tauris. 
Neumaier, M. (2012a). Destruction and rebuilding: The university between 1689 and 1803. In P. Meusburger \& T. Schuch (Eds.), Wissenschaftsatlas of Heidelberg University: Spatiotemporal relations of academic knowledge production (pp. 72-75). Knittlingen: Bibliotheca Palatina.

Neumaier, M. (2012b). Regional provenance and living conditions of students and lecturers ca. 1588. In P. Meusburger \& T. Schuch (Eds.), Wissenschaftsatlas of Heidelberg University: Spatio-temporal relations of academic knowledge production (pp. 70-71). Knittlingen: Bibliotheca Palatina.

Offner, R. (2006). Deutsche Universitäten als Ausbildungsstätten siebenbürgischer Mediziner von den Anfängen bis zum Jahr 1850 [German universities as training institutions of Transylvanian physicians from their beginning to the year1850]. In M. Fata, G. Kurucz, \& A. Schindling (Eds.), Peregrinatio Hungarica: Studenten aus Ungarn an deutschen und österreichischen Hochschulen vom 16. bis zum 20. Jahrhundert (pp. 287-343). Contubernium-Tübinger Beiträge zur Universitäts- und Wissenschaftsgeschichte: Vol. 64. Stuttgart: Steiner.

Pánek, J. (2003). Friedrich V von der Pfalz als König von Böhmen [Friedrich V of the Palatinate as king of Bohemia]. In P. Wolf, M. Henker, E. Brockhoff, B. Steinherr, \& S. Lippold (Eds.), Der Winterkönig Friedrich V, Der letzte Kurfürst aus der Pfalz. Amberg, Heidelberg, Prag, Den Haag (pp. 101-106). Veröffentlichungen zur Bayerischen Geschichte und Kultur: 46/03. Augsburg: Haus der Bayerischen Geschichte.

Pánek, J., \& Polívka, M. (2005). Die böhmischen Adelsreisen und ihr Wandel vom Mittelalter zur Neuzeit [The Cavalier's Tours of Bohemian noblemen and their change from the Middle Ages to the Modern Age]. In R. Babel \& W. Paravicini (Eds.), Grand Tour: Adeliges Reisen und europäische Kultur vom 14. bis zum 18. Jahrhundert. Akten der internationalen Kolloquien in der Villa Vigoni 1999 und im Deutschen Historischen Institut in Paris 2000 (pp. 53-69). Beihefte der Francia: Vol. 60. Ostfildern: Jan Thorbecke.

Paravicini, W. (2005). Die Grand Tour in der europäischen Geschichte: Zusammenfassung [A summary of the Grand Tour in European history]. In R. Babel \& W. Paravicini (Eds.), Grand Tour: Adeliges Reisen und europäische Kultur vom 14. bis zum 18. Jahrhundert. Akten der internationalen Kolloquien in der Villa Vigoni 1999 und im Deutschen Historischen Institut in Paris 2000 (pp. 657-674). Beihefte der Francia: Vol. 60. Ostfildern: Jan Thorbecke.

Pareus, D. (1614). Irenicum sive de unione et synodo evangelicorum concilianda liber votivus, paci ecclesiae et desideriis pacificorum dictatus a Davide Pareo [Peacemaker, or an assembly for reconciling the Evangelicals, a book dedicated by David Pareus to the peace of the church and the desire of peace-loving people]. Heidelberg: Jonae Rosae librarij. Retrieved from http:// reader.digitale-sammlungen.de/de/fs1/object/display/bsb10360874_00005.html

Pfetsch, F. R. (1974). Zur Entwicklung der Wissenschaftspolitik in Deutschland 1750-1914 [The development of science policy in Germany, 1750-1914]. Berlin: Duncker \& Humblot.

Pukánszky, B., \& Németh, A. (1996). Neveléstörténet [History of education]. Budapest: Nemzeti Tankönyvkiadó.

Rasche, U. (2006). Von Fichte zu Metternich: Die Universität Jena und ihre ungarländischen Studenten um 1800. [From Fichte to Metternich: Jena University and its students from Hungary at 1800]. In M. Fata, G. Kurucz, \& A. Schindling (Eds.), Peregrinatio Hungarica: Studenten aus Ungarn an deutschen und österreichischen Hochschulen vom 16. bis zum 20. Jahrhundert (pp. 197-226). Contubernium-Tübinger Beiträge zur Universitäts- und Wissenschaftsgeschichte: Vol. 64. Stuttgart: Steiner.

Reich, K. (2010). Johannes Stöffler: Melanchthons Tübinger Lehrer in Mathematik und Astronomie [Johannes Stöffler: Melanchthon's mathematics and astronomy teacher in Tübingen]. In S. Lorenz, R. Rieger, E. Seidl, \& K. Wiegmann (Eds.), Vom Schüler der Burse zum „,Lehrer Deutschlands ": Philipp Melanchthon in Tübingen (pp. 139-151). Tübinger Kataloge: Vol. 88. Tübingen: Universitätsstadt Tübingen, Fachbereich Kultur, Stadtmuseum.

Richarz, M. (1974). Der Eintritt der Juden in die akademischen Berufe: Jüdische Studenten und Akademiker in Deutschland 1678-1848 [The entry of Jews into the academic professions: Jewish students and academics in Germany, 1678-1848]. Tübingen: Mohr. 
Rieger, R. (2010). Melanchthons Weg zur reformatorischen Theologie [Melanchthon's path to Reformed theology]. In S. Lorenz, R. Rieger, E. Seidl, \& K. Wiegmann (Eds.), Vom Schüler der Burse zum „Lehrer Deutschlands“: Philipp Melanchthon in Tübingen (pp. 153-159). Tübinger Kataloge: Vol. 88. Tübingen: Universitätsstadt Tübingen, Fachbereich Kultur, Stadtmuseum.

Röhrs, H. (1971). Die Studienzeit des Comenius in Heidelberg [Comenius as a student at Heidelberg University]. Heidelberger Jahrbücher, 15, 1-12.

Rotzoll, M. (2012). Plagues and wars in the early history of Heidelberg University. In P. Meusburger \& T. Schuch (Eds.), Wissenschaftsatlas of Heidelberg University: Spatiotemporal relations of academic knowledge production (pp. 52-53). Knittlingen: Bibliotheca Palatina.

Scheible, H. (1983). Die Universität Heidelberg und Luthers Disputation [Heidelberg University and Luther's disputation]. Zeitschrift für die Geschichte des Oberrheins, 131, 92 (Neue Folge), 309-329.

Scheible, H. (1985). Melanchthons Beziehungen zum Donau-Karpaten-Raum bis 1546 [Melanchthon's relations to the Danube-Carpathian area until 1546]. In G. Weber \& R. Weber (Eds.), Luther und Siebenbürgen: Ausstrahlungen von Reformation und Humanismus nach Südosteuropa (pp. 36-67). Siebenbürgisches Archiv: Vol. 19. Cologne: Böhlau.

Schilling, H. (2010). Calvin und Calvinismus in europageschichtlicher Perspektive [Calvin and Calvinism from a European historical perspective]. In M. Fata \& A. Schindling (Eds.), Calvin und Reformiertentum in Ungarn und Siebenbürgen: Helvetisches Bekenntnis, Ethnie und Politik vom 16. Jahrhundert bis 1918 (pp. 1-21). Reformationsgeschichtliche Studien und Texte: Vol. 155. Münster: Aschendorff.

Schindling, A. (2006). Bildungsinstitutionen im Heiligen Römischen Reich deutscher Nation als Ziele der studentischen Migration: Wanderungen im Zeichen von Konfessionen und geistigen Strömungen [Educational institutions in the Holy Roman Empire of the German Nation as destinations of student migration: Migrations marked by denominations and spiritual trends]. In M Fata, G. Kurucz, \& A. Schindling (Eds.), Peregrinatio Hungarica: Studenten aus Ungarn an deutschen und österreichischen Hochschulen vom 16. bis zum 20. Jahrhundert (pp. 39-54). Contubernium-Tübinger Beiträge zur Universitäts- und Wissenschaftsgeschichte: Vol. 64. Stuttgart: Steiner.

Schmidt-Rösler, A. (2006). Princeps Transilvaniae-Rex Hungariae? Gabriel Bethlens Außenpolitik zwischen Krieg und Frieden [Prince of Transylvania-King of Hungary? Gabriel Bethlen's foreign policy between war and peace]. In Duchhardt H \& M Peters (Eds.), KalkülTransfer-Symbol: Europäische Friedensverträge der Vormoderne (pp. 80-98). Veröffentlichungen des Instituts für Europäische Geschichte, Mainz: Beiheft online 1. Retrieved from http://www.iegmainz.de/vieg-online-beihefte/01-2006.html

Schönebaum, H. (1926). Die ungarischen Universitäten im Mittelalter [The Hungarian universities in medieval times]. Archiv für Kulturgeschichte, 16, 41-59.

Schweitzer, F., Lorenz, S., \& Seidl, E. (Eds.). (2010). Philipp Melanchthon: Seine Bedeutung für Kirche und Theologie, Bildung und Wissenschaft [Philipp Melanchton: His significance for the church and theology and for education and science]. Theologie Interdisziplinär: Vol. 8. Neukirchen-Vluyn: Neukirchener Verlagsgesellschaft.

Schwinges, R. C. (1982). Immatrikulationsfrequenz und Einzugsbereich der Universität Gießen 1650-1800: Zur Grundlegung einer Sozialgeschichte Gießener Studenten [Registration rate and catchment area of the University of Gießen, 1650-1800: Establishing the basis for a social history of Gießen's students]. In P. Moraw \& V. Press (Eds.), Academia Gissensis: Beiträge zur älteren Gießener Universitätsgeschichte (pp. 247-295). Veröffentlichungen der Historischen Kommission für Hessen: Vol. 45. Marburg: Elwert.

Schwinges, R. C. (1984). Universitätsbesuch im Reich vom 14. zum 16. Jahrhundert: Wachstum und Konjunkturen [University attendance in the empire between the fourteenth and sixteenth centuries: Growth and fluctuation]. Geschichte und Gesellschaft: Zeitschrift für Historische Sozialwissenschaften, 10, 5-30. 
Schwinges, R. C. (1986). Deutsche Universitätsbesucher im 14. und 15. Jahrhundert: Studien zur Sozialgeschichte des Alten Reiches [German university students in the fourteenth and fifteenth centuries: Studies on the social history of the old empire]. Veröffentlichungen des Instituts für Europäische Geschichte Mainz: Vol. 123, Beiträge zur Sozial- und Verfassungsgeschichte des Alten Reiches: Vol. 6. Stuttgart: Steiner

Schwinges, R. C. (1988). Migration und Austausch: Studentenwanderungen im Deutschen Reich des Mittelalters [Migration and exchange: Student migration in the medieval German empire]. In G. Jaritz \& A. Müller (Eds.), Migration in der Feudalgesellschaft (pp. 141-155). Frankfurt am Main \& New York: Campus.

Schwinges, R. C. (1994). Franken in der deutschen Universitätslandschaft des späten Mittelalters [Franconia in the German university landscape of the late Middle Ages]. In H.-A. Steger \& H. Hopfinger (Eds.), Die Universität in der Welt-Die Welt in der Universität (pp. 1-26). Neustadt an der Aisch: Degener.

Schwinges, R. C. (1998). The medieval German university: Transformation and innovation. Paedagogica Historica: International Journal of the History of Education, 34, 375-388.

Schwinges, R. C. (2000). On recruitment in German universities from the fourteenth to sixteenth centuries. In W. J. Courtenay \& J. Miethke (Eds.), Universities and schooling in medieval society (pp. 32-48). Education and Society in the Middle Ages and Renaissance: Vol. 10. Leiden: Brill.

Schwinges, R. C. (2001). Innovationsräume und Universitäten in der älteren deutschen Vormoderne [Innovative spaces and universities in early German premodernity]. In R. C. Schwinges, P. Messerli, \& T. Münger (Eds.), Innovationsräume: Woher das Neue kommt-In Vergangenheit und Gegenwart (pp. 31-44). Zürich: vdf Hochschulverlag AG an der ETH Zürich.

Schwinges, R. C. (2005). Die Universität als sozialer Ort des Adels [The university as a social space of the nobility]. In R. Babel \& W. Paravicini (Eds.), Grand Tour: Adeliges Reisen und europäische Kultur vom 14. bis zum 18. Jahrhundert. Akten der internationalen Kolloquien in der Villa Vigoni 1999 und im Deutschen Historischen Institut in Paris 2000 (pp. 357-372). Beihefte der Francia: Vol. 60. Ostfildern: Jan Thorbecke.

Schwinges, R. C. (2006). Das Reich im gelehrten Europa: Ein Essay aus personengeschichtlicher Perspektive [The Reich in scholarly Europe: An essay from the personal history perspective]. In B. Schneidmüller \& S. Weinfurter (Eds.), Heilig-Römisch-Deutsch: Das Reich im mittelalterlichen Europa (pp. 227-250). Dresden: Michael Sandstein.

Sebók, L. (2013). A magyarországi zsidók a számok tükrében [The Jews in Hungary in the mirror of the numbers]. Rubiconline, 4. Retrieved from http://www.rubicon.hu/magyar/oldalak/a magyarorszagi_zsidok_a_szamok_tukreben/

Seebaß, G. (1983). Die Heidelberger Disputation [The Heidelberg disputation]. Heidelberger Jahrbücher, 27, 77-88.

Seidel, R. (2004). Der ungarische Späthumanismus und die calvinistische Pfalz [Hungarian late Humanism and the Calvinist Palatinate]. In W. Kühlmann \& A. Schindling (Eds.), Deutschland und Ungarn in ihren Bildungs- und Wissenschaftsbeziehungen während der Renaissance (pp. 227-251). Contubernium-Tübinger Beiträge zur Universitäts- und Wissenschaftsgeschichte: Vol. 62. Stuttgart: Steiner.

Siebe, D. (2006). Studierende aus Ungarn an den Universitäten Berlin und Heidelberg zwischen 1870 und 1932/33 [Students from Hungary at the universities of Berlin and Heidelberg between 1870 and 1932-1933]. In M. Fata, G. Kurucz, \& A. Schindling (Eds.), Peregrinatio Hungarica. Studenten aus Ungarn an deutschen und österreichischen Hochschulen vom 16. bis zum 20. Jahrhundert (pp. 409-436). Contubernium-Tübinger Beiträge zur Universitäts- und Wissenschaftsgeschichte: Vol. 64. Stuttgart: Steiner.

Sienerth, S. (2007). Leseangebot und Buchzirkulation in Siebenbürgen zwischen Humanismus und Aufklärung [Supply and circulation of books in Transylvania between Humanism and the Enlightenment]. In D. Haberland (Ed.), Buch- und Wissenstransfer in Ostmittel- und Südosteuropa in der Frühen Neuzeit (pp. 281-309). Munich: Oldenbourg. 
Sipos, G. (2010). Zur Bedeutung des Reformierten Kollegiums Nagyenyed für die siebenbürgische Kultur vom 17. bis zum 19. Jahrhundert [The importance of the Reformed college Nagyenyed for Transylvanian culture from the seventeenth to the nineteenth century]. In M. Fata \& A. Schindling (Eds.), Calvin und Reformiertentum in Ungarn und Siebenbürgen: Helvetisches Bekenntnis, Ethnie und Politik vom 16. Jahrhundert bis 1918 (pp. 261-281). Reformationsgeschichtliche Studien und Texte: Vol. 155. Münster: Aschendorff.

Stagl, J. (1995). A history of curiosity: The theory of travel 1550-1800. Studies in Anthropology and History: Vol. 13. Chur: Harwood Academic Publishers.

Stempel, H.-A. (1993). Melanchthon. In T. Bautz (Ed.), Biographisch-Bibliographisches Kirchenlexikon: Vol. 5. Leyden, Nikolaus to Mönch, Antonius (pp. 1184-1188). Hamm: Bautz. http://www.bbkl.de.ubproxy.ub.uni-heidelberg.de/lexikon/bbkl-artikel.php?wt=1\& art $=. / \mathrm{M} / \mathrm{Mc}-\mathrm{Me} / \mathrm{melanchton}$.art

Stickler, M. (2006). Die Selbstorganisation der Studenten aus dem Königreich Ungarn an deutschen und österreichischen Hochschulen zwischen 1871 und 1918 [The self-organization of students from the Kingdom of Hungary at German and Austrian universities between 1871 and 1918]. In M. Fata, G. Kurucz, \& A. Schindling (Eds.), Peregrinatio Hungarica: Studenten aus Ungarn an deutschen und österreichischen Hochschulen vom 16. bis zum 20. Jahrhundert (pp. 471-503). Contubernium-Tübinger Beiträge zur Universitäts- und Wissenschaftsgeschichte: Vol. 64. Stuttgart: Steiner.

Stievermann, D. (1999). Friedrich der Weise und seine Universität Wittenberg [Frederick the Wise and his University of Wittenberg]. In S. Lorenz (Ed.), Attempto-oder wie stiftet man eine Universität: Die Universitätsgründungen der sogannten zweiten Gründungswelle im Vergleich (pp. 175-207). Contubernium-Tübinger Beiträge zur Universitäts- und Wissenschaftsgeschichte: Vol. 50. Stuttgart: Steiner.

Stokes, G. (1989). The social origins of east European politics. In D. Chirot (Ed.), The origins of backwardness in eastern Europe: Economics and politics from the Middle Ages to the early twentieth century (pp. 210-251). Berkeley: University of California Press.

Strohm, C., \& Becker, M. (2012). Western European influences on the Faculty of Law, 1560 to 1620. In P. Meusburger \& T. Schuch (Eds.), Wissenschaftsatlas of Heidelberg University: Spatio-temporal relations of academic knowledge production (pp. 64-65). Knittlingen: Bibliotheca Palatina.

Strohm, C., \& Hofmann, A. (2012). The university as a spiritual centre of "Reformed" Europe. In P. Meusburger \& T. Schuch (Eds.), Wissenschaftsatlas of Heidelberg University: Spatiotemporal relations of academic knowledge production (pp. 62-63). Knittlingen: Bibliotheca Palatina.

Stupperich, R. (1990). Melanchthon, Philipp. In Neue Deutsche Biographie: Vol. 16. MalyMelanchthon (pp. 741-745). Berlin: Duncker \& Humblot. Retrieved from https://www. deutsche-biographie.de/gnd1 18580485.html\#ndbcontent

Stupperich, R. (1996). Philipp Melanchthon: Gelehrter und Politiker [Philipp Melanchthon: Scholar and politician]. Göttingen: Muster-Schmidt.

Szabó, A. (1992). Die soziale Struktur der Universitaetsstudentenschaft im Spiegel der ungarischen Studenten zu Wittenberg [The social structure of university students as reflected by Hungarian students at Wittenberg]. In A. Buck \& T. Klaniczay (Eds.), Sozialgeschichtliche Fragestellungen in der Renaissanceforschung (pp. 41-48). Wolfenbütteler Abhandlungen zur Renaissanceforschung: Vol. 13. Wiesbaden: Harrassowitz.

Szabó, A. (1993). Magyarok Wittenbergben 1555-1592 [Hungarians in Wittenberg, 1555-1592]. In I. Békési, J. Jankovics, L. Kosa, \& J. Nyerges (Eds.), Régi és új peregrináció-Magyarok külföldön, külföldiek Magyarországon II (pp. 626-635). Budapest: Nemzetközi Magyar Filológiai Társaság. ScriptumKft.

Szabó, A. (1999a). Albert Szenci Molnár in Schlesien [Albert Szenci Molnár in Silesia]. In A. Szabó (Ed.), Iter Germanicum: Deutschland und die Reformierte Kirche in Ungarn im 16.-17. Jahrhundert (pp. 201-213). Budapest: Calvin 
Szabó, A. (1999b). Ungarische Studenten in Wittenberg [Hungarian students in Wittenberg]. In A. Szabó (Ed.), Iter Germanicum: Deutschland und die Reformierte Kirche in Ungarn im 16.-17. Jahrhundert (pp. 155-168). Budapest: Calvin.

Szabó, A. (2003). Szenczi Molnár Albert naplója [Diary of Albert Szenczi Molnár]. Historia Litteraria: Vol. 13. Budapest: Universitas.

Szabó, A. (2005-2007). Akten über ungarische Studenten im Heidelberger Universitaetsarchiv [Files on Hungarian students in the Heidelberg university archive]. Ungarn-Jahrbuch: Zeitschrift für interdisziplinäre Hungarologie, 28, 227-236.

Szabó, A. (2006). Die Universität Wittenberg als zentraler Studienort im 16. Jahrhundert [Wittenberg University as a key place to study in sixteenth century]. In M. Fata, G. Kurucz, \& A. Schindling (Eds.), Peregrinatio Hungarica:Studenten aus Ungarn an deutschen und österreichischen Hochschulen vom 16. bis zum 20. Jahrhundert (pp. 55-63). ContuberniumTübinger Beiträge zur Universitäts- und Wissenschaftsgeschichte: Vol. 64. Stuttgart: Steiner.

Szabó, A. (2010). Calvinismus und Ethnie im Reich der Stephanskrone im 16. Jahrhundert [Calvinism and ethnicity in the lands of Saint Stephen's Crown in the sixteenth century]. In M Fata \& A Schindling (Eds.), Calvin und Reformiertentum in Ungarn und Siebenbürgen: Helvetisches Bekenntnis, Ethnie und Politik vom 16. Jahrhundert bis 1918 (pp. 81-89). Reformationsgeschichtliche Studien und Texte: Vol. 155. Münster: Aschendorff.

Szögi, L. (1995). Régi magyar egyetemek emlékezete [Memories of old Hungarian universities]. Budapest: ELTE Könyvtár és Levéltár. Retrieved from http://www.mek.oszk.hu/01800/01882/ 01882.htm

Szögi, L. (2001). Magyarországi diákok németországi egyetemeken és fóiskolákon: 1789-1919. Ungarländische Studenten an den deutschen Universitäten und Hochschulen: 1789-1919 [Hungarian students at German universities and colleges: 1789-1919]. Budapest: Eötvös Loránd Tudományegyetem Levéltára.

Szögi, L. (2004). Külföldi egyetemi modellek és külföldi egyetemi tanulmányok a 18. századtól a 20. század elsố negyedéig [University models and studies abroad from the eighteenth century to the first quarter of the nineteenth century]. In G. Palló (Ed.), Recepció és kreativitás-Teremtó befogadás (Összefüggések. tanulságok) (pp. 129-197). Budapest: Áron Kiadó.

Szögi, L. (2006). Studenten aus Ungarn und Siebenbürgen an den deutschen Universitäten 17891919 [Students from Hungary and Transylvania at German universities, 1789-1919]. In M. Fata, G. Kurucz, \& A. Schindling (Eds.), Peregrinatio Hungarica: Studenten aus Ungarn an deutschen und österreichischen Hochschulen vom 16. bis zum 20. Jahrhundert (pp. 387-408). Contubernium-Tübinger Beiträge zur Universitäts- und Wissenschaftsgeschichte: Vol. 64. Stuttgart: Steiner.

Szögi, L. (2008). Die Universitäten in Ungarn: Gründungswellen vom späten Mittelalter bis ins 20. Jahrhundert [Universities in Hungary: Waves of foundings from late medieval times into the twentieth century]. In P. Wörster (Ed.), Universitäten im östlichen Mitteleuropa: Zwischen Kirche, Staat und Nation. Sozialgeschichtliche und politische Entwicklungen (pp. 235-267). Völker, Staaten und Kulturen in Ostmitteleuropa: Vol. 3. Munich: Oldenbourg.

Tar, A. S. (2007). Magyar-német felsóoktatási kapcsolatok és kölcsönhatások a 18.-19. században [Hungarian-German relations and interactions in higher education during the eighteenth and nineteenth centuries] (Doctoral thesis, Eötvös Loránd Unversity, Budapest, Hungary). Retrieved from http://www.doktori.btk.elte.hu/hist/tar/disszert.pdf

Taylor, P. J., Hoyler, M., \& Evans, D. M. (2010). A geohistorical study of "The rise of modern science": Mapping scientific practice through urban networks, 1500-1900. In P. Meusburger, D. N. Livingstone, \& H. Jöns (Eds.), Geographies of science (pp. 37-56). Knowledge and Space: Vol. 3. Dordrecht: Springer. doi:https://doi.org/10.1007/978-90-481-8611-2_3

Teutsch, F. (1872). Die Studierenden aus Ungarn und Siebenbürgen auf der Hochschule in Heidelberg von der Gründung derselben bis 1810 [Students from Hungary and Transylvania at Heidelberg University from its founding to 1810]. Archiv des Vereins für siebenbürgische Landeskunde, 10 (Neue Folge), 182-192.

Thomas, M. (Ed.). (2015). Expedition into empire: Exploratory journeys and the making of the modern world. New York: Routledge. 
Titze, H. (1987). Das Hochschulstudium in Preußen und Deutschland 1820-1944: Datenhandbuch zur deutschen Bildungsgeschichte [University study in Prussia and Germany, 1820-1944: Data on German educational history]. Vol. 1, Pt. 1. Göttingen: Vandenhoeck \& Ruprecht.

Toepke, G. (Ed.). (1886). Die Matrikel der Universität Heidelberg: Bd. 2. Von 1554-1662 [The registries of Heidelberg University: Vol. 2. 1554-1662]. Heidelberg: Winter. Retrieved from http://digi.ub.uni-heidelberg.de/matrikel1554

Toepke, G., \& Hintzelmann, K. (Eds.). (1903). Die Matrikel der Universität Heidelberg: Bd. 4. Von 1704-1807 [The registries of Heidelberg University: Vol. 4. 1704-1807]. Heidelberg: Winter. Retrieved from http://digi.ub.uni-heidelberg.de/matrikel1704

Toepke, G., \& Hintzelmann, K. (Eds.). (1904). Die Matrikel der Universität Heidelberg: Bd. 5. Von 1807-1845 [The registries of Heidelberg University: Vol. 5. 1807-1845]. Heidelberg: Winter. Retrieved from http://digi.ub.uni-heidelberg.de/matrikel1807

Toepke, G., \& Hintzelmann, K. (Eds.). (1906). Die Matrikel der Universität Heidelberg: Bd. 6. Von 1846-1870 [The registries of Heidelberg University: Vol. 6. 1846-1870]. Heidelberg: Winter. Retrieved from http://digi.ub.uni-heidelberg.de/matrikel1846

Tökéczki, L. (2010). Liberalismus und Reformiertentum zur Zeit des österreichisch-ungarischen Dualismus: Das Beispiel István Tiszas [Liberalism and Reformed churches during AustrianHungarian dualism: The example of István Tisza]. In M. Fata \& A. Schindling (Eds.), Calvin und Reformiertentum in Ungarn und Siebenbürgen: Helvetisches Bekenntnis, Ethnie und Politik vom 16. Jahrhundert bis 1918 (pp. 377-394). Reformationsgeschichtliche Studien und Texte: Vol. 155. Münster: Aschendorff.

Tonk, S. (1979). Erdélyiek egyetemjárása a középkorban [Peregrination of Transylvanian students in the Middle Ages]. Bukarest: Kriterion.

Tonk, S., \& Szabó, M. (1993). Erdélyiek egyetemjárása a középkor és koraújkor folyamán. [Peregrination of Transylvanian students in the Middle Ages and Early Modern times]. In I. Békési, J. Jankovics, L. Kosa, \& J. Nyerges (Eds.), Régi és új peregrináció: Magyarok külföldön, külföldiek Magyarországon II (pp. 491-500). Budapest: Nemzetközi Magyar Filológiai Társaság. Scriptum Kft.

Ugry, B. (2014). A megismerés és az információszerzés új útjain: Magyarok kora újkori európai utazásainak forrásai és jelentôségük az információtörténeti kutatások számára [On new ways of cognition and acquiring information: Sources on travels of Hungarians in the Early Modern Age and their importance for the research on information history]. Jel-Kép, 25(3). doi:https://doi.org/ 10.20520/Jel-Kep.2014.3.6

Ulrichs, K. F. (1993). David Pareus. In T. Bautz (Ed.). Biographisch-Bibliographisches Kirchenlexikon: Vol. 6. Moenius-Patijn (pp. 1532-1536). Hamm: Bautz.

Vámos, E. (2006, September 6-9). Three generations of natural scientists in Hungary, 1848-1918. In M. Kokowski (Ed.), The global and the local: The history of science and the cultural integration of Europe (pp. 274-288). Proceedings of the 2nd ICESHS, Cracow, Poland. Retrieved from http://www.academia.edu/7596114/Michal_Kokowski_ed._The_Global_and_ the_Local_The_History_of_Science_and_the_Cultural_Integration_of_Europe._Proceedings_ of_the_2nd_International_Conference_of_the_European_Society_for_the_History_of_Sci ence_Cracow_Poland_September_6-9_2006_

Varga, J. (2001). Protestantische Hochschulbildung in Siebenbürgen vom 16. Jahrhundert bis zur Mitte des 19. Jahrhunderts [Protestant university education in Transylvania from the 16th to the mid-nineteenth century]. In L. Szögi \& M. Font (Eds.), Die Ungarische Universitätsbildung und Europa (pp. 173-182). Pécs: Universitas Quinqueecclesiensis.

Varga, P. (2003). „man sprach deutsch und fühlte nichtmagyarisch . ..”: Assimilationsprozesse in der deutschen und jüdischen Bevölkerung von Pest-Buda im 19. Jahrhundert ["We spoke German and felt non-Hungarian . ...: Processes of assimilation in the German and Jewish populations of Pest-Buda in the nineteenth century]. In H. Hecker \& W. Engel (Eds.), Symbiose und Traditionsbruch: Deutsch-jüdische Wechselbeziehungen in Ostmittel- und Südosteuropa im 19. und 20. Jahrhundert (pp. 173-182). Essen: Klartext. 
Vásárhelyi, J. P. (1985). Eszmei áramlatok és politika Szenczi Molnár Albert életmúvében [Ideological trends and politics in the oeuvre of Albert Szenczi Molnár]. Humanizmus és reformáció: Vol. 12. Budapest: Akadémiai Kiadó.

Vásárhelyi, J. P. (1999). Johann Piscator und Albert Szenci Molnár [Johann Piscator und Albert Szenci Molnár]. In A Szabó (Ed.), Iter Germanicum: Deutschland und die Reformierte Kirche in Ungarn im 16.-17. Jahrhundert (pp. 191-200). Budapest: Calvin.

Vásárhelyi, J. P. (2006). Szenczi Molnár Albert és a Vizsolyi Biblia új kiadásai [Albert Szenczi Molnár and the new editions of the Vizsoly Bible]. Historia Litteraria: Vol. 21. Budapest: Universitas.

Vásárhelyi, J. P. (2014). The role of Szenci Molnár in the exchange of ideas and political knowledge among the European Calvinist principalities in the early seventeenth century. In G. Almási (Ed.), Study tours and intellectual-religious relationships (pp. 121-144). A divided Hungary in Europe: Exchanges, networks and representations, 1541-1699. Vol. 1. Cambridge, UK: Cambridge Scholar Publishing.

Vékás, L. (2001). Wissenschaftleraustausch und geistige Wiedervereinigung Europas [Exchange of scientists and spiritual reunification of Europe]. In Europa Institute Budapest (Ed.), Begegnungen (pp. 137-143). Schriftenreihe des Europa Institutes Budapest: Vol. 12. Budapest: Europa-Institut.

Verger, J. (1970). Le recrutement géographique des universités françaises au début de $15^{\mathrm{e}}$ siècle d'après les suppliques de 1403 [The recruiting catchment areas of French universities as of the early fifteenth century after the petitions of 1403]. Mélanges d'Archéologie et d'Histoire, 82, 855-902.

Viskolcz, N. (2010). Johann Heinrich Bisterfeld: Ein Professor als Vermittler zwischen West und Ost an der siebenbürgischen Akademie in Weißenburg 1630-1655 [Johann Heinrich Bisterfeld: A professor as intermediary between West and East at the Transylvanian academy in Weissenburg, 1630-1655]. In M Fata \& A Schindling (Eds.), Calvin und Reformiertentum in Ungarn und Siebenbürgen: Helvetisches Bekenntnis, Ethnie und Politik vom 16. Jahrhundert bis 1918 (pp. 201-214). Reformationsgeschichtliche Studien und Texte: Vol. 155. Münster: Aschendorff.

Volkov, S. (1987). Soziale Ursachen des Erfolgs in der Wissenschaft: Juden im Kaiserreich [Social causes of success in science: Jews in the German empire]. Historische Zeitschrift, 245, 315-342. Retrieved from http://www.jstor.org/stable/27625826

Vorlaufer, J. (1993). Lukács, Georg. In T. Bautz (Ed.), Biographisch-Bibliographisches Kirchenlexikon: Vol. 5. Leyden, Nikolaus to Mönch, Antonius (pp. 401-404). Hamm: Bautz. http://www.bbkl.de.ubproxy.ub.uni-heidelberg.de/lexikon/bbkl-artikel.php?wt=1\&art=./L/Lu/ lukacs.art

Wessely, A. (1986). Diskurs über die Kunst im Sonntagskreis [Discourse about arts in the Sunday Circle]. In H. Gaßner (Ed.), Wechselwirkungen: Ungarische Avantgarde in der Weimarer Republik (pp. 541-553). Marburg: Jonas.

Wolgast, E. (1986). Die Universität Heidelberg 1386-1986 [Heidelberg University, 1386-1986]. Berlin: Springer.

Wolgast, E. (1987). Phönix aus der Asche? Die Reorganisation der Universität Heidelberg zu Beginn des 19. Jahrhunderts [Phoenix out of the ashes? The reorganization of Heidelberg University in the early nineteenth century]. In F Strack (Ed.), Heidelberg im säkularen Umbruch: Traditionsbewusstsein und Kulturpolitik um 1800 (pp. 35-60). Stuttgart: Klett-Cotta.

Wolgast, E. (1996). Die Universität Heidelberg: Historische Entwicklung [Heidelberg University: Historical development]. In E Mittler (Ed.), Heidelberg: Geschichte und Gestalt (pp. 284-320). Heidelberg: Winter.

Wolgast, E. (1998). Späthumanismus in Heidelberg [Late Humanism in Heidelberg]. In E Wolgast (Ed.), Reformierte Konfession und Politik im 16. Jahrhundert: Studien zur Geschichte der Kurpfalz im Reformationszeitalter (pp. 98-114) Schriften der Philosophisch-Historischen Klasse der Heidelberger Akademie der Wissenschaften: Vol. 10. Heidelberg: Winter. 
Wolgast, E. (2015). Die Universität Heidelberg in ihrer internationalen Vernetzung in den Jahren 1559-1622 [Heidelberg University in its international network, 1559-1622]. In C. Strohm \& J. Stievermann (Eds.), Profil und Wirkung des Heidelberger Katechismus: Neue Forschungsbeiträge anläßlich des 450jährigen Jubiläums. The Heidelberg Catechism: Origins, characteristics, and influences: Essays in reappraisal on the occasion of its 450th anniversary (pp. 89-112). Schriften des Vereins für Reformationsgeschichte: Vol. 215. Gütersloh: Gütersloher Verlagshaus.

Zach, K. (2004). „Eine kleine Biblia”-Rezeption und Resonanz des reformationszeitlichen Katechismus im historischen Ungarn (1530-1640) ["A small biblia"-Reception and resonance of catechisms of the Reformation in historical Hungary (1530-1640)]. In W. Kühlmann \& A. Schindling (Eds.), Deutschland und Ungarn in ihren Bildungs- und Wissenschaftsbeziehungen während der Renaissance (pp. 151-183). Contubernium-Tübinger Beiträge zur Universitäts- und Wissenschaftsgeschichte: Vol. 62. Stuttgart: Steiner.

Zepf, R. (2001). Fructus Uberrimi: Die Theologiestudenten von Collegium Sapientiae und Universität Heidelberg 1550-1622 [Fructus Uberrimi: Theology students of the Collegium Sapientiae and Heidelberg University, 1550-1622]. In A Kohnle \& F Engehausen (Eds.), Zwischen Wissenschaft und Politik: Studien zur deutschen Universitätsgeschichte. Festschrift für Eike Wolgast (pp. 441-454). Stuttgart: Steiner.

Zhang, G. (2013). Fehlgründungen von Universitäten im Spätmittelalter: Motive und Bedingungen für die Entstehung der mittelalterlichen Universität [Abortive creation of universities in late medieval times: Motives and conditions for the rise of the medieval university]. Hamburg: Kovac.

Zvara, E. (2012). Ceglédi Szabó Pál dunántúli református püspök könyvei [The books of Pál Ceglédi Szabó, Calvinist superintendent of Transdanubia]. Magyar Könyvszemle, 128, 293-317.

Open Access This chapter is licensed under the terms of the Creative Commons Attribution 4.0 International License (http://creativecommons.org/licenses/by/4.0/), which permits use, sharing, adaptation, distribution and reproduction in any medium or format, as long as you give appropriate credit to the original author(s) and the source, provide a link to the Creative Commons license and indicate if changes were made.

The images or other third party material in this chapter are included in the chapter's Creative Commons license, unless indicated otherwise in a credit line to the material. If material is not included in the chapter's Creative Commons license and your intended use is not permitted by statutory regulation or exceeds the permitted use, you will need to obtain permission directly from the copyright holder. 